\title{
Three Essays on the
} Development of the Labor Market and the Private Sector in Burma (Myanmar)

Saw Htay Wah

This document was submitted as a dissertation in December 2015 in partial fulfillment of the requirements of the doctoral degree in public policy analysis at the Pardee RAND Graduate School. The faculty

committee that supervised and approved the dissertation consisted of Arie Kapteyn (Chair), Joanne Yoong, and David Powell.

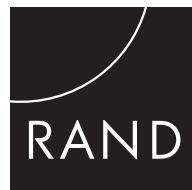

PARDEE RAND GRADUATE SCHOOL 
For more information on this publication, visit http://www.rand.org/pubs/rgs_dissertations/RGSD367.html

Published by the RAND Corporation, Santa Monica, Calif.

C Copyright 2016 RAND Corporation

RAND $^{\circledR}$ is a registered trademark

\section{Limited Print and Electronic Distribution Rights}

This document and trademark(s) contained herein are protected by law. This representation of RAND intellectual property is provided for noncommercial use only. Unauthorized posting of this publication online is prohibited. Permission is given to duplicate this document for personal use only, as long as it is unaltered and complete. Permission is required from RAND to reproduce, or reuse in another form, any of its research documents for commercial use. For information on reprint and linking permissions, please visit www.rand.org/pubs/permissions.html.

The RAND Corporation is a research organization that develops solutions to public policy challenges to help make communities throughout the world safer and more secure, healthier and more prosperous. RAND is nonprofit, nonpartisan, and committed to the public interest.

RAND's publications do not necessarily reflect the opinions of its research clients and sponsors.

Support RAND

Make a tax-deductible charitable contribution at

www.rand.org/giving/contribute

www.rand.org 


\begin{abstract}
Prior research suggests that access to credit, access to electricity, access to public services, access to skilled labor, and ethnic discrimination in the labor market are the top constraints inhibiting the development of the labor markets and the private sector in Burma. This dissertation, in the form of three essays, addresses each of the five top constraints.
\end{abstract}

Small and medium enterprises (SMEs) play a major role in the Burmese economy, making up over $95 \%$ of all private enterprises and employing the majority of the labor force. This suggests that the development of a well-functioning and thriving private sector is crucial to sustained growth over time. Yet, little is known about the characteristics of SMEs, the business environment under which they operate, and the factors affecting their growth. Employing vignette methodology and using data from a field survey of SMEs that I conducted in the city of Yangon in 2014, the first essay analyzes the critical barriers to access to the three areas of business inputs (credit, electricity, and public services), and makes suggestions for improving access. I find few interactions between banks and SMEs, that access to bank credit is very limited and difficult (in part due to strict collateral requirements), and that loan programs targeted towards SMEs have not improved access to credit, despite its popularity among government officials, donors, and NGOs. My findings suggest that policies aimed at restoring and regaining trust and enhancing transparency in the banking system, as well as relaxing existing collateral requirements will be effective in improving access to bank credit. Another implication of the main findings is that a scale-up of the SME loan program that allows for improving the program design over time will be more effective than a full-scale implementation. In addition to generating results that have important policy implications, this paper is the first study to show that self-reports of traditional business environment measures are affected by differences in the response scales that individuals use and propose a statistical method to correct for these differences.

The second essay addresses another major constraint facing employers - access to skilled labor. One potential solution to narrow or close the skills gap would be to rely on the skills of return migrants who accumulated sufficient skills in more advanced countries. This research experimentally investigates the demand for return migrants who accumulate skills in more developed foreign countries in skills-intensive occupations, relative to equivalent workers who accumulate the same skills in local labor markets. While audit studies have provided critical evidence about labor market discrimination in developed countries, I apply this method to the Burmese labor market. I find evidence that foreign experience is favored by employers for certain occupations. Specifically, software developers and programmers with foreign experience, Singapore experience in particular, are highly favored by foreign employers. Among accountants and engineers, I find no systematic and significant difference in callback rates between foreign and local applicants. In addition to foreign experience, I also find differences in callback rates by gender and neighborhood. Specifically, female accountants are highly favored, while female engineers are less favored by employers. As for neighborhood effect, software developers and programmers living in a rich neighborhood receive as many first callbacks from employers as those having Singapore experience. One direct policy implication that arises from findings from this research is that return migration policies targeting specific occupation and employer will be more effective than a single policy targeting all occupations and employers. Since, this is the first 
labor market audit study performed in a developing country, I also discuss the constraints and challenges that one faces with this type of research in a developing country and then propose measures to overcome these challenges.

The third essay explores potential ethnic discrimination in Myanmar's labor market. Ethnic minorities constitute approximately $40 \%$ of the Myanmar population of 51 million. Yet, little is known about the experiences and context of ethnic groups in Myanmar and their labor market outcomes. Ample anecdotal evidence indicate that ethnic minorities are highly discriminated against in the public sector that is largely dominated by majority ethnic Burmans. Given this precedent in the public sector, minority communities are concerned that they will also be targets of discrimination in the private sector in which a majority of employers are majority Burmans. The third essay uses audit methodology to examine whether employers in the private sector discriminate against ethnic minorities. Overall, I do not find significant evidence suggesting that ethnic minorities are racially discriminated against. In contrast, one particular minority group, ethnic Karen, is found to be preferred by employers in the private sector, compared with ethnic Burman. As for other minority groups, there are no differences in employers' responses between ethnic minorities and majority Burman. The same analysis should be extended to the public and non-profit sectors given their economic significance. While audit studies have provided critical evidence about labor market discrimination in developed countries, this is the first labor market audit study performed in a developing country to uncover racial discrimination.

Taken together, these three essays provide a comprehensive examination of the most pressing constraints to Burma's economic growth during this period of unprecedented political independence. This dissertation describes the current landscape of Burma's labor market and private sector, and offers policymakers concrete suggestions for encouraging healthy economic development during these critical years. 


\section{Table of Contents}

Acknowledgments

List of Tables

vii

List of Figures

ix

List of Appendices

$\mathrm{xi}$

ESSAY 1

xiii

1. INTRODUCTION

2. DATA

a. Respondent Characteristics $\quad 5$

b. Business Characteristics 6

c. Capital and Loan Variables $\quad 6$

d. Public Sector Variables $\quad 7$

e. Electricity Variables $\quad 8$

f. Ranking of the Three Business Domains $\quad 8$

3. VIGNETTE DESCRIPTIONS 9

a. Variations in Vignettes 10

b. Summary Statistics of Vignette Evaluations 11

c. Distributions of Vignette Evaluations 12

d. Vignette Regressions 14

4. THE THEORY OF VIGNETTES 17

5. ECONOMETRIC MODEL 18

a. Self-Evaluations $\quad 18$

$\begin{array}{ll}\text { b. Vignette Evaluations } & 20\end{array}$

6. RESULTS 21

a. Credit 21

b. Electricity 22

c. Public services 23

7. CONCLUSION 24

a. Suggestions for future research 26

ESSAY 2

1. INTRODUCTION 283

2. RELATED LITERATURE 27

3. EXPERIMENTAL DESIGN 29

a. Resume Construction 90 
b. Sample and data 92

4. EMPIRICAL ANALYSIS

a. Dependent Variable 92

b. Independent Variables 93

c. Empirical Models 93

5. EXPERIMENTAL RESULTS 94

a. Main results (Outcome: first callback) 94

b. By occupation (Outcome: first callback) 94

c. By occupation (Outcome: only one applicant receives callback) 98

d. By neighborhood (Outcome: first callback) 98

e. By gender (Outcome: first callback) 99

6. CONCLUSION 99

$\begin{array}{lr}\text { ESSAY } 3 & 120\end{array}$

1. INTRODUCTION 121

2. RELATED LITERATURE 125

3. EXPERIMENTAL DESIGN 127

a. Resume Construction 128

b. Sample and data 130

4. EMPIRICAL ANALYSIS 130

a. Dependent Variables 131

b. Independent Variables 131

c. Empirical Models 131

5. RESULTS 132

a. Main results 132

b. By pair resumes (Outcome: only one applicant receives callback) 133

6. CONCLUSION 134 


\section{Acknowledgments}

I'd like to express my profound gratitude to each of my committee members Arie Kapteyn (Chair), Joanne Yoong, and David Powell for their helpful insights, and research guidance. Were it not for their strong intellectual leadership and mentorship, this dissertation wouldn't have been completed in a timely manner. Arie Kapteyn provided incredible leadership and support throughout all stages of the dissertation, including reviewing my proposals in the early stages and providing invaluable comments and suggestions on all my drafts and ideas. David Powell thoroughly reviewed my economic work and write-up of the analysis, and provided invaluable comments. Joanne Yoong was very influential in nudging me to the right direction whenever I veered off in my research. I am thankful to my outside reader, Wallace Huffman at Iowa State University, for his continuous support and mentorship even after my departure from the Economics Department at Iowa State in early 2010.

This dissertation was financially supported by the Anne and James Rothenberg Dissertation Award, the Eugene and Maxine Rosenfeld Dissertation Award, the Don Conlan Dissertaion Award, the Center for Economic and Social Research (CESR) at the University of Southern California, the Civil Society Scholar Award, and the Private Enterprise Development in LowIncome Countries (PEDL) Grant. I thank Pardee RAND Graduate School Dean's Leadership Circle member, Don Conlan, for his support that enabled me to attend the graduate school.

I am indebted to Tania Gutsche, Adrian Montero, Bart Orriens, and Bas Weerman of the University of Southern California for their assistance with developing the Computer Assisted Personal Interviewing (CAPI) software infrastructure on which the field work was based. This software infrastructure made my life a lot easier, and most importantly, saved my study.

This dissertation would not have been possible without the technical and field support of many individuals inside Burma. Salai Aung Min Hlaing of Opportunity Journal kindly provided an electronic copy of the journal each week for a total of 20 weeks that made it possible for me to conduct the labor market audit study from a remote location 8,260 miles away from the experimental setting in Yangon. Ko TheinWin Tun of Value Added Consultancy (VAC), and Ko Wai Phyo Kyaw and Ko Wai Yan Lin of www.myanmarjobsdb.com supplied hundreds of resumes that informed the construction of the resume templates used in the field experiment. Ko Tun Tun Naing and his team worked tirelessly, preparing thousands of resumes, answering hundreds of callbacks, entering field data, and transmitting the field data back to me on a weekly basis. Field staff from Professional Research and Consultancy Group (PRC) diligently and skillfully administered close to 1,000 face-to-face interviews in the Greater Yangon Areas.

My graduate school experience was greatly enriched by my interactions with fellow students and friends, in particular Shira Efron, Christina Huang, Sung-Bou Kim, Tyler Lippert, Nelly Mejia, and Youngbok Ryu. Their camaraderie made my graduate student life more enjoyable. I thank Christina Huang who carefully reviewed and provided valuable feedback on the dissertation at different stages, and Tyler Lipper for editorial assistance on several occasions. I am also very grateful for the support from the administration, faculty and staff of the Pardee RAND Graduate School. 
Finally, I want to thank my parents for their unfailing and unconditional love. I dedicate this dissertation to them. 


\section{List of Tables}

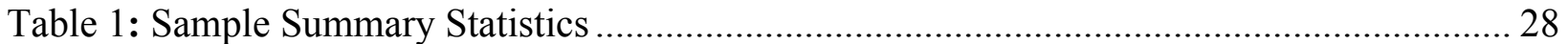

Table 2: Dependent Variable: Credit, Electricity, and Public Service Is Ranked First;

Independent Variables: Self-Reports Of Difficulty on a 5-Point Scale .................................... 30

Table 3: Dependent Variable: Credit, Electricity, and Public Services Is Ranked First ............. 31

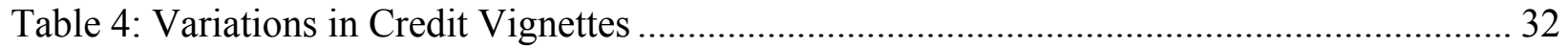

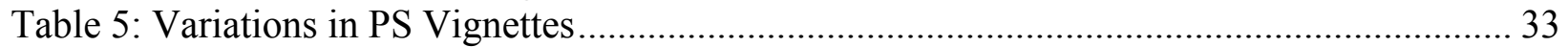

Table 6: Variations in Electricity Vignettes.................................................................... 34

Table 7: Summary Statistics of Vignette Evaluations ......................................................... 35

Table 8: Sample Statistics of Characrtersitics in Credit Vignettes .......................................... 37

Table 9: Sample Statistics of Characrtersitics in PS Vignettes................................................ 38

Table 10: Sample Statistics of Characrtersitics in Electricity Vignettes .................................. 39

Table 11: Effects of Credit Vignette Descriptions on Evaluations .......................................... 39

Table 12: Effects of PS Vignette Descriptions on Evaluations .............................................. 40

Table 13: Effects of Electricity Vignette Descriptions on Evaluations ..................................... 40

Table 14: Estimates of Ordered Logit and CHOPIT Models (Dependent Variable: Subjective

Measures of Credit Difficulty on a 5-point Scale) ................................................................. 41

Table 15: Estimates of Ordered Logit and CHOPIT Models (Dependent Variable: Subjective

Measures of Electricity Difficulty on a 5-point Scale) ...................................................... 42

Table 16: Estimates of Ordered Logit and CHOPIT Models (Dependent Variable: Subjective

Measures of Public Service Difficulty on a 5-point Scale) .................................................. 43

Table 17: Comparison of experimental design across resume-based audit studies .................. 102

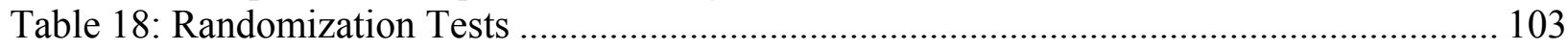

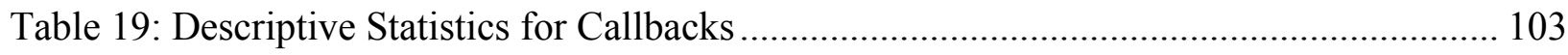

Table 20: Descriptive Statistics of Independent Variables .................................................. 103

Table 21: Dependent variable: if a resume is the first to receive a callback for an interview ... 104

Table 22: Dependent variable: if a resume is the first to receive a callback for an interview .... 105

Table 23: Dependent variable: if a resume is the first to receive a callback for an interview ... 106

Table 24: Dependent variable: if a resume is the first to receive a callback for an interview .... 107

Table 25: Dependent variable: if a resume is the first to receive a callback for an interview .... 108

Table 26: Dependent variable: if a resume is the first to receive a callback for an interview .... 109

Table 27: Dependent variable: if a resume is the first to receive a callback for an interview ... 110

Table 28: Dependent variable: If a resume receives a callback for a job interview .................. 111

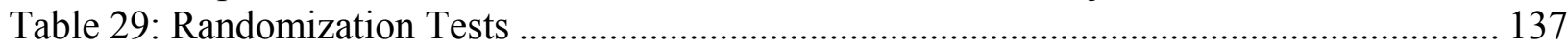

Table 30: Descriptive Statistics for Callbacks ................................................................... 137

Table 31: Descriptive Statistics of Independent Variables .................................................. 137

Table 32: Dependent variable: if a resume is the first to receive a callback for an interview .... 138

Table 33: Dependent variable: if a resume is the first to receive a callback for an interview ... 139

Table 34: Callbacks by employers when deciding to call back only one applicant from pairs of

Karen Vs Burman applicants, Chin Vs Burman applicants, Kachin Vs Shan applicants, and Shan

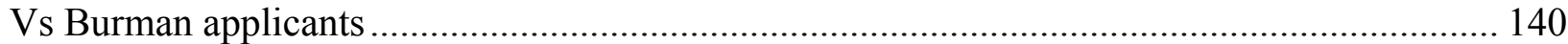





\section{List of Figures}

Figure 1: Top Constraint by Business Domain................................................................. 30

Figure 2: Distributions of Vignette Evaluations: Credit...................................................... 36

Figure 3: Distribution of Vignette Evaluations: Public Services ............................................ 36

Figure 4: Distribution of Vignette Evaluations: Electricity ............................................... 37

Figure 5: Comparing Self-Reports Of Business Climate in Two Sub-Groups in The Case of DIF:

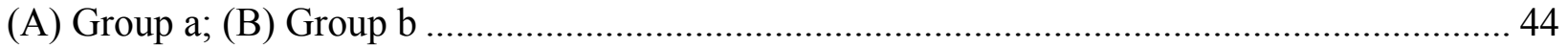





\section{List of Appendices}

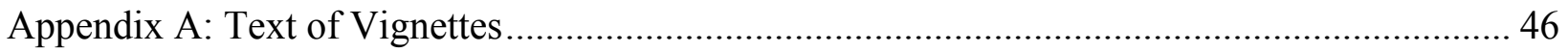

Appendix B: List of Survey Items Used In Existing Enterprise Surveys .................................... 49

Appendix C: Estimates of Vignette Dummies and Variances in Equation 4 ............................... 50

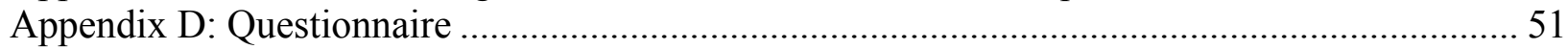

Appendix E: Distribution of Sample Job Openings................................................................ 114

Appendix F: Distribution of Sample by Week …………………………………………....... 115

Appendix G: List of Variables and Their Detailed Descriptions............................................... 116

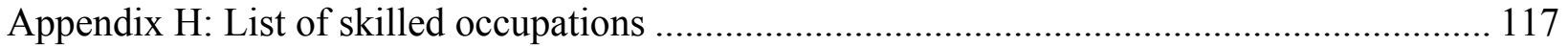

Appendix I: Location Maps of the Zip Codes used in Resumes.................................................. 118

Appendix J: Institutional Review Board (IRB) Approval ....................................................... 119

Appendix K: List of names used in the resumes by ethnic group by gender............................. 143

Appendix L: Distribution of Sample by Week ……….......................................................... 144

Appendix M: List of Variables and Their Detailed Descriptions ............................................. 145

Appendix N: Institutional Review Board (IRB) Approval ....................................................... 146 



\title{
ESSAY 1
}

\section{Using Anchoring Vignettes to Enhance Comparability Of Self-Reports Of Business Environment Measures and Identify Barriers to Access to Credit, Electricity, and Public Services}

\author{
Saw Htay Wah
}

\begin{abstract}
Small and medium enterprises (SMEs) play a major role in the Burmese economy, making up over $95 \%$ of all private enterprises and employing the majority of the labor force. This suggests that the development of a well-functioning and thriving private sector is crucial to sustained growth over time. Yet, little is known about the characteristics of SMEs, the business environment under which they operate, and the factors affecting their growth. Employing vignette methodology and using data from a field survey of SMEs that I conducted in the city of Yangon in 2014, this study analyzes the critical barriers to access to the three areas of business inputs (credit, electricity, and public services), and makes suggestions for improving access. I find few interactions between banks and SMEs, that access to bank credit is very limited and difficult (in part due to strict collateral requirements), and that loan programs targeted towards SMEs have not improved access to credit, despite its popularity among government officials, donors, and NGOs. My findings suggest that policies aimed at restoring and regaining trust and enhancing transparency in the banking system, as well as relaxing existing collateral requirements will be effective in improving access to bank credit. Another implication of the main findings is that a scale-up of the SME loan program that allows for improving the program design over time will be more effective than a full-scale implementation. In addition to generating results that have important policy implications, this paper is the first study to show that self-reports of traditional business environment measures are affected by differences in the response scales that individuals use and propose a statistical method to correct for these differences.
\end{abstract}




\section{INTRODUCTION}

Enterprise surveys fielded across countries provide valuable sources of information in business environment research. Part of the enterprise surveys pertain to individuals' rating of different aspects of the business environment ("To what extent is [an aspect of the business environment] an obstacle to the current operations of this establishment?") on a 5-point scale from (1) no obstacle to (5) severe obstacle. A host of questions on topics including government regulations, access to land, political stability, corruption, tax policy, and access to skilled labor are asked of respondents to assess the performance of a country's business environment (See Appendix B for a full list of the 18 subjective measures currently used in the World Bank's enterprise surveys).

A major limitation with the subjective measures is that one has to assume that response scales are the same across individuals within a country or across countries. This assumption can be problematic in diverse settings where the scale one uses to self-report the business environment on a categorical scale can be affected by different socioeconomic backgrounds (such as education, age, gender, and ethnicity), cultural norms, and differences in political and economic systems. For instance, two individuals within a country or from two countries may differ on what it means to be "severe" when reporting one aspect of the business environment (for instance access to skilled labor) that equally affects both individuals.

In addition, individuals' self-assessments involve two cognitive processes: (1) evaluation of their own reality, and (2) translation of the self-assessed reality into a categorical response on a subjective scale. For instance, when asked to report the extent to which access to credit is an obstacle to them on a traditional 5-point scale, individuals will first assess their true obstacle and then translate the assessed obstacle into what it means to be above or below a given threshold (such as "difficulty" and "very difficult"). How an individual locates herself/himself between thresholds becomes a function of the reality of her/his own situation, as well as her/his unique set of subjective thresholds.

With that in mind, it is clear that comparing subjective measures across respondents within a country or across countries is fraught with the potential identification issue that different groups may use different response scales. Specifically, since both objective realities and subjective thresholds may vary across individuals, using subjective responses alone is not sufficient to identify how much of the variations in subjective outcomes across individuals are 
attributable to true differences, and how much are attributable to variations in their subjective thresholds.

Self-reported business environment data have been used in numerous cross-country empirical studies as well as in generating country reports. Given their potential for influencing policy decisions, it is important to investigate if the self-reported data are affected by bias induced by heterogeneity in reporting behavior and then to propose a statistical method to correct for the bias.

Anchoring vignettes offer the potential to address reporting bias in business environment research. These vignettes are short descriptions of hypothetical business owners facing varying degrees of barriers in the business environment (for instance difficulty in receiving electricity, or having to pay bribes to government officials. See Appendix B for a full list). Respondents are then asked to evaluate vignette business owners on the same scale as they evaluate themselves. Information from vignette evaluations provides the basis for assessing if response scales are different across respondents and correcting for such differences.

Evidence of response scale differences (both within and across countries) has been documented in prior studies. Kapteyn et al. $(2009,2013)$ find systematic differences in what it means to be happy in life in general and with respect to one's income across individuals within the US and the Netherlands, as well as across individuals between the two countries. Vonkova et al. (2015) find students across countries use different reporting styles when evaluating their teachers' classroom performance. Banks et al. (2009) find that Americans are more likely to selfreport better health, compared with their British counterparts, while more objective health measures suggest the exact opposite. Similarly, Grol-Prokopczyk et al. (2011) find that women tend to be more health-optimistic compared with men. Bago d'Uva et al. (2008) and SV Subramanian et al. (2009) report systematic differences in what "good health" means across countries. When using self-reports of alcoholic drinks among students enrolled at an Irish University, Soest et al. (2011) find no difference in drinking behavior between Irish students and international students, but when using more objective measures of drinking, the authors find that Irish students have a more tolerant attitude toward drinking and thus are less likely to report that drinking is a major issue for them. Puzzled by a large difference in the percentage of the population claiming to be work disabled between the US and the Netherlands, Kapteyn et al. (2007) find that a large part of observed differences in reported work disability between the two 
countries is largely due to different response scales: Dutch respondents have a lower response threshold in claiming disability than Americans do. Similarly, Kristensen and Johansson (2008) find systematic differences in response scales individuals from seven EU countries use when self-reporting their job satisfaction.

Despite their widespread use in many important studies, vignettes have never been applied to the business environment research. In this paper, I report results from a study conducted in the Yangon area of Myanmar that aims to investigate if self-reports of business environment measures are affected by differences in response scales individuals use, focusing on three key areas of the business environment: (1) access to credit, (2) access to public services ${ }^{1}$ (PS hereafter), and (3) access to electricity. These three areas are chosen because they are considered the most severe constraints facing small and medium enterprises (SMEs) ${ }^{2}$ in Myanmar (OECD, 2013; Aung Kyaw, 2008; Masato Abe and Madhurjya Kumar Dutta, 2014). In addition to uncovering response scale differences, anchoring vignettes will help identify major barriers to access to the three areas facing SMEs that has the potential for better informing policy decisions.

The remainder of this paper is organized into six sections. Section 2 describes data that are used in this analysis. Section 3 presents vignette descriptions, evaluations, distributions of responses, and the estimated effects of vignette characteristics on evaluations. Section 4 outlines the underlying theory and intuition behind the use of vignettes, and then Section 5 presents the more formal econometric model to test if responses scales are different across respondents. Section 6 presents the empirical estimates of the model. The final section discusses the implications of the results, followed by suggestions for future research.

\section{DATA}

Data are from two surveys, which were field tested in the city of Yangon from June 2014 to November 2014. The first survey collects information on a random sample of approximately 900 SMEs in the Yangon area of Myanmar through structured interviews with business owners.

\footnotetext{
${ }^{1}$ My working definition of access to public services is the amount of resources a business has to allocate (i.e., money or time, or both) toward acquiring public services that are essential for the business to function; these services can be completing routine administrative paperwork, applying for licenses and permits, travelling to the capital city to complete an administrative paperwork, or the time interacting with government officials and agencies.

${ }^{2}$ For this research, I define SMEs based on employment size similar to the World Bank's definitions: an enterprise is considered small if it employs 5-19 employees and medium if it employs 20-99 employees.
} 
Selection into the study was based on three criteria: (1) small or medium size (i.e., more than 5 employees and less than 100 employees); (2) listed in the 2014 Edition of the Yangon Directory; and (3) located within Yangon area. I used the 2014 Edition of the Yangon Directory as the sampling frame, which was stratified by size, industry, and geographical location. Independent samples were then drawn in each stratum proportional to the size of the stratum, ensuing that businesses in all sub-groups had a chance of being included. Each sampled enterprise was contacted via telephone to schedule an appointment for interview with the owner ${ }^{3}$.

The second survey collects information on a sample of approximately 100 minority enterprises (i.e. businesses which are at least $51 \%$ owned, operated and controlled on a daily basis by Myanmar citizens of one or more of the following ethnic minorities: Kachin, Kayah, Karen, Chin, Mon, Rakhine, and/or Shan ethnic minority) in the Yangon area. As no sampling frame exists for the minority population, I employed a snowball sampling approach. The snowball sampling involved visiting communities across Yangon and contacting ethnic and religious leaders to locate and interview minority enterprises.

The questionnaires for both surveys were identical to ensure uniformity and are provided in Appendix D. I merge data from the two surveys to generate a unique dataset for this research. The topics covered in the questionnaire included: (1) firm and respondent characteristics, (2) capital and access to credit, (3) access to public services, (4) access to electricity, (5) ranking of business climate domains, and (6) evaluations of vignette descriptions. The following describes the sample statistics, which are provided in Table 1.

\section{a. Respondent Characteristics}

The data reveal that about half of sample respondents have historical ties to entrepreneurship, with $51 \%$ of them reporting growing up in a family owning at least one business. When asked about their fathers' occupation, the same percent $(51 \%)$ of respondents mention that their fathers own and manage family businesses. About 35\% of respondents report owing a business prior to establishing their current business. Of those who owned a prior business, 34\% mention that their prior businesses produced similar goods and services as their current businesses do.

\footnotetext{
${ }^{3}$ I strictly required that respondents were either owners or co-owners. The survey contains subjective and qualitative questions that only owners could answer more accurately. I however accepted non-owner respondents in situations where the owners are no longer actively involved in businesses operations. Non-owner respondents make up less than $15 \%$ of the sample.
} 
As for ethnic composition, $61 \%$ of sample respondents identify themselves as ethnic Burmese, 16\% ethnic minorities, 12\% Chinese, and 8\% Indians.

With regard to self-reported educational attainment, about $31 \%$ of respondents can be categorized into low education group (below high school, high school, and vocational training), 59\% medium education group (associate and bachelor degree), and 9\% high education group (advanced and professional degree).

About $74 \%$ of sample respondents are male, $80 \%$ are married, $36 \%$ are aged between 19 and 39, 36\% between 40 and 50, 24\% between 51 and 64, and 5\% are aged 65 and above. About $86 \%$ of respondents report being business owners, and conditional on being owners, $99 \%$ are actively managing day to day operations of the businesses. The average work experience of sample respondents is 11.92 years.

\section{b. Business Characteristics}

Small-size businesses make up a majority (73\%) of the sample. About 211 of the sample businesses $(21 \%)$ are located in industrial zones. About $16 \%$ of the sample SMEs sold goods or services to the Myanmar government in the past two years. The average years a business has been operational is 14.20 years.

The data suggest a racial gap in SME ownership. Conditional on respondents being owners ( $86 \%$ of sample SMEs), Chinese and Indian owners account for $21 \%$ of sample SMEs, which far exceeds their population share of less than 5\%. Ethnic minority owners account for about $15 \%$ of sample SMEs, which falls short of their population share of $30-40 \%{ }^{4}$ of the Myanmar population of 51 million.

\section{c. Capital and Loan Variables}

A majority of sample SMEs rely on personal funds as startup capital. When asked what the main sources of startup capital are, $89 \%$ report personal or family savings, or assets. Just 5\% of respondents report using bank loans as startup capital. As for the source of finance for business operations or expansions in the past two years, about $69 \%$ of sample SMEs report

\footnotetext{
${ }^{4}$ This statistic should be interpreted with extreme caution as official statistics on populations of ethnic minorities are not available; the accuracy of the statistic can't be verified (Source: https://www.cia.gov/library/publications/theworld-factbook/geos/bm.html). The Myanmar Census was conducted in 2014. However, the official Census report provides no information on ethnic composition of Myanmar population (Visit http://countryoffice.unfpa.org/myanmar/census/ for more information about the 2014 Myanmar Census).
} 
relying on retained profits and business assets, and 52\% report using personal/family saving(s) of owners.

With regard to access to bank loans, 151 SMEs (15\% of the sample) report applying for bank loans in the past two years. Conditional on applying for bank loans in the past two years, the average number of bank loan applications is 1.4 and $93 \%$ of loan applications are approved. The average bank loan amount is US\$271,000, and the average collateral value per loan is US\$ 1.5 million, suggesting that on average a SME is able to borrow $19 \%$ of the collateral value. The average bank loan maturity is 12 months, and the average bank interest is $13 \%$-- the same as the maximums allowed by existing banking rules and regulations. Conditional on applying and receiving bank loans in the past two years, $76 \%$ of sample SMEs report using the loans to finance business expansion, $29 \%$ to acquire of new capital/improving existing capital, and $21 \%$ to finance regular business operations. Only $2 \%$ of sample SMEs report using the loans to pay back existing debts.

There are limited interactions between SMEs and the banking sector as indicated by the data. On average, just $17 \%$ of sample SMEs report having received any bank loans since establishing. About $85 \%$ of sample SMEs did not apply for any bank loans in the past two years. When asked the primary reasons for not applying, 41\% mention that they didn't understand or were not familiar with procedures for bank loans, or loan procedures were lengthy and complicated, and 19\% cite a lack of collateral banks required or not enough collateral value.

While bank lending to SMEs is very limited, informal lending is quite common and provides the main source of financing for most SMEs. On average, 23\% of sample SMEs report receiving personal loans from informal sources (i.e., friends or relatives) in the past 2 years. The average number of loans is 4.2 , the average loan amount is US\$ 84,000 , and the average interest is $39 \%$ (these compare to 1.4 , US\$ 271,000 , and $13 \%$, respectively, for formal lending).

\section{d. Public Sector Variables}

For most Myanmar SMEs, daily business activities include interactions with various government agencies. A majority of these interactions occur at the capital city, Naypyidaw, which is home to government agencies and ministries, located 200 miles north of Yangon. A trip to Naypyidaw from Yangon can take up to 6 hours by private car.

Approximately $20 \%$ of sample respondents report making any business related trips to the capital from Yangon in the past 6 months. The most mentioned purposes of the trips are to 
(1) meet government officials or attend meetings (68\%), or (2) secure new contracts or business opportunities from the government (42\%), or (3) complete any administrative paperwork (26\%). Of sample respondents making business related trips to the capital in the past 6 months, the average number of trips is 5.8, with each trip lasting 2.5 days and costing US\$190.00 on average.

One way a business can reduce the transaction costs associated with travelling to the capital from Yangon is to establish a branch office in the capital city. The data indicate that $4 \%$ of sample SMEs have branch offices in the capital. Another way is to utilize the services of a third party or an agent based in the capital $-25 \%$ of sample respondents report utilizing these services in the past 6 months.

\section{e. Electricity Variables}

According to an estimate by the International Energy Agency (2012), only $49 \%$ of the Myanmar population has access to electricity. Of areas served by electricity, insufficient voltages

and power outages are very common. About $97 \%$ of sample SMEs report experiencing outage in every month in the past year, and the average number of outages per month is 12.9 with each outage lasting 3.3 hours on average. About $70 \%$ of sample SMEs report owning a private generator. Typically, the use of private generator corresponds to the number and duration of outages experienced.

Although electric resources are available, they are costly, difficulty to get, and inconsistent. About $8 \%$ of sample SMEs report applying for a new connection in the past 12 months, and $41 \%$ of them are required to buy a transformer, which may explain the high average cost of a new connection (US\$21,000). The average number of days to get a new connection is 48.5 days.

\section{f. Ranking of the Three Business Domains}

In addition to self-reports of difficulty in access to each of the three business domains, respondents also rank the three business domains from most difficulty to least difficulty. The distribution of their responses is presented in Figure 1. About 54\% of sample respondents rank access to credit as the most difficult, $24 \%$ access to electricity, and $22 \%$ access to public services. 
To assess if the order of the ranking correlates with self-reports of difficulty, I create three dummies indicating if a given business domain is ranked first (i.e., most difficult), and then regress these dummies on self-reports of difficulty. Table 2 reports the results, which show a significant and positive relationship between if a business domain is ranked first and self-reports of difficulty. For instance, a one point increase in self-reports of difficulty (remember the scale runs from 1 being "no difficulty" to 5 being "severe difficulty") in access to credit is associated with a 10 percentage point increase in the likelihood that it will be ranked first. Similarly, a one point increase in self-reports of difficulty in access to electricity and public services is positively associated with a 11.8 and 12.4 percentage point increase in the odds that they will be ranked first, respectively.

I next regress the three dummies on a set of subgroup dummies that include (1) 19-39, 40-50, 61-64, 65+ age groups (with 19-39 as the reference group), (2) low, medium, high education groups (with low education group as the reference group), (3) if a respondent is ethnic Burmese (with ethnic minorities as the reference group), (4) if a respondents is male (with female as the reference group), (5) if a respondent is owner (with non-owner respondents as the reference group), (6) if a business is small-size (with medium-size as the reference group), (7) if a business is directly selling goods/services to the government (with not selling as the reference group), and (8) if a business is located in an industrial zone (with businesses located in nonindustrial zones as the reference group).

Table 3 presents the results. SMEs located in industrial zones are 18 percentage points more likely to rank electricity first and 8 percentage points less likely to rank public services first. In contrast, SMEs selling goods or services to government agencies are 8 percentage points more likely to rank public services first and 11 percentage points less likely to rank electricity first.

\section{VIGNETTE DESCRIPTIONS}

I wrote three series of vignettes covering access to (1) credit, (2) public services, and (3) electricity. The credit series consist of 12 vignettes, the public service series 9 vignettes, and the electricity series 9 vignettes. In short, vignettes are short descriptions of hypothetical business owners facing varying degrees of barriers to access to services in the three business domains. The complete scenarios described in the vignettes in each series are provided in Appendix A. All 
vignettes were assigned neutral sounding names to eliminate any effects associated with names, and were presented in random order so that it is possible to control for possible order effects by which earlier vignettes may affect the evaluations of subsequent vignettes. Each respondent was presented with 3 randomly chosen vignettes in each of the three series and asked to evaluate the vignette persons on a 5-point scale: (1) no difficulty; (2) mild difficulty; (3) moderate; (4) major difficulty; (5) severe difficulty.

\section{a. Variations in Vignettes}

Table 4, Table 5, and Table 6 present summaries of variations across credit, public services, and electricity vignettes.

There are six potential ways a vignette in credit domain can vary: (1) loan amount (US\$ $30,000$ or US\$ 100,000$)$; (2) annual interest $(13 \%, 18 \%, 24 \%, 36 \%$, or $48 \%)$; (3) source of loan (friends/relatives, commercial bank, or SME bank) ; (4) collateral requirement (whether a loan requires collateral or not); (5) type of collateral if collateral is required (land, house, or apartment); and (6) collateral value $\mathrm{e}^{5}$ if collateral is required $(100 \%, 200 \%$, or $300 \%$ of the loan amount). If a loan is from a bank, the interest is fixed at $13 \%$-- the maximum allowable interest a bank can charge under prevailing banking rules and regulations. If a loan is from friends/relatives, the interest ranges from $18 \%$ to $48 \%$. Currently, banks only accept empty land, or houses, or both as collateral. To be considered as valid collateral, borrowers must be the registered and sole owners of the collateralized assets. Apartments or luxurious apartments such as condominium are more relaxed collateral, but they are not accepted as collateral by banks.

There are 8 potential ways a vignette in public service domain can vary: (1) costs to acquire a public service; (2) number of days it takes to receive a public service; (3) number of official procedures involved to complete an administrative paperwork; (4) whether the administrative paperwork can be completed in Yangon; (5) whether the administrative paperwork can be completed online; (6) whether a trip to the capital city is required to complete the administrative paperwork; (7) number of days it takes to get invoices approved; and (8) number of official signatures required to get invoices approved.

There are 9 potential ways a vignette in electricity domain can vary: (1) costs to secure a new electricity connection, (2) number of days it takes to secure a new connection, (3) if a

\footnotetext{
${ }^{5}$ Collateral values are usually forced-sales values, meaning the value one will receive if one needs to sell the collateral tomorrow. As such, forced-sales values are significantly lower than market values.
} 
business is located in an industrial zone, (4) total hours a business has to operate a generator due to power outage or insufficient voltage, (5) whether a business has no access to electricity at all, (6) whether a generator is used to mainly power air conditioning due to insufficient voltage, (7) whether an application for new electricity connection is pending, (8) whether a business has to operate without electricity for an hour each day, and (9) whether a business rarely experiences power outage and insufficient power voltage.

Although I wrote the vignettes before I could learn about the sample SMEs, the characteristics present in the vignettes are approximate characterizations of variations among sample SMEs. For instance, credit vignette 12 describes a vignette owner who has no access to credit -- a situation faced by a majority of SMEs, particularly among small-size businesses. Existing banking regulations only allow land or houses, or both to be used as collateral provided borrowers are the sole and registered owners. This strict collateral requirement is reflected in vignettes $7,8,9$, and 10 . Some vignettes describe new policies or a relaxation to existing policies, or policies under discussion. For instance, there is an ongoing discussion among policy makers and the donor community about the creation of SME banks ${ }^{6}$ that will exclusively cater to the credit needs of SME population. Vignette 11 represents this scenario where the vignette owner is granted a collateral-free loan from a newly-created SME bank at 13\% interest; vignette 9 exemplifies a relaxation to existing stringent collateral requirement by allowing the vignette owner to place his/her apartment as collateral, which will in turn enable us to evaluate the impacts of allowing apartment as collateral, relative to land and house.

\section{b. Summary Statistics of Vignette Evaluations}

Table 7 presents summary statistics of vignette evaluations by business environment domain. The last column shows the percentage of sample respondents who answer either "major" or "severe" difficulty. Among vignette owners relying on friends/relatives for finance, evaluation is positively associated with interest (Figure 2). The average evaluation of vignette owner 1 who receives a loan worth US\$ 30,000 from friends/relatives at $18 \%$ is 2.53 , which is followed by the average evaluations of vignette owners 2,4 , and 6 that each receive the same loan as vignette 1 but are required to pay a higher interest of $24 \%, 36 \%$, and $48 \%$, respectively.

\footnotetext{
${ }^{6}$ The Small and Medium Industrial Development Bank (SMIDB), a state-owned bank, is the only bank that is currently making credit available to a small and very specific group of SMEs. Commercial banks don't offer financial products that exclusively serve the SME population, citing prohibitive and strict regulations.
} 
Compared to vignette owner 8 who receives a bank loan worth US\$100,000 using his own house and land as collateral, the average evaluation as well as the percentage of respondents who answer "major" or "severe" are smaller for vignette owner 9 who receives the same bank loan but is permitted to use his apartment as collateral. Increase in collateral value (vignettes 7 , 8, and 10) and the receipt of an SME bank loan (vignette 11) have no discernible impacts on evaluations in terms of the percentage of respondents who answer "major" or "severe". The mean evaluation and the percentage of respondents who answer "major" or "severe" are the largest for vignette 12 which describes an owner that has no access to credit.

The second panel lists summary statistics of vignette evaluations in the public service domain. The mean evaluations of vignette owners 3 and 5 who can complete any administrative paperwork either online or in Yangon are the lowest, indicating few perceived difficulties. The mean evaluations of vignette $6,1,9$ that more or less reflect the existing bureaucratic environment fare the worst. The mean evaluations of vignette owners 8, 2, 7, 4 who face a more efficient bureaucratic environment relative to the existing one come in between.

The last panel shows summary statistics of vignette evaluations in electricity domain. The mean evaluations of vignettes 5 and 9 that describe businesses rarely experiencing outage and using generator to mainly power office air conditioning are the lowest. The mean evaluations of vignette owner 8 who on average has to do without electricity for an hour each day due to outage comes next. As expected, vignette owners 4 and 6 - the former having no access to electricity for his brick making factor and the latter experiencing 8 hours of outage each day - rank the worst, preceded only by vignettes 2 and 3 that describe businesses sustaining 6 and 4 hours of outage each day, respectively.

\section{c. Distributions of Vignette Evaluations}

Figure 2 lists the distributions of evaluations of credit vignettes. The numbers along the horizontal axis match the vignette numbers provided in Appendix A.

As can be seen in the left panel in Figure 2, the evaluations are more likely to be "major" and "severe" with increasing interest. Compared with responses for vignette owner 2 who doesn't have to pledge any collateral, the responses for vignette owner 3 who is required to pledge an apartment as collateral are more concentrated in the right end tail of the scale (i.e., more difficulty). 
The right panel in Figure 2 lists the distributions of evaluations for vignette owners who receive loans from either banks or SME banks (vignettes 7 to 11), and vignette owner 12 who relies on self-financing. Looking at the distributions across vignettes 7 to 11 , one can notice that the evaluations are significantly less likely to be "major" or "severe" when an apartment is permitted as collateral for a bank loan as in vignette 9 . Responses for vignette 12 , the worst case scenario, are heavily concentrated in the right end tail of the scale -- $80 \%$ of respondents answer "moderate", "major", or "severe" when describing this owner.

Figure 3 presents the distributions of evaluations in public service domain, broken down by vignette number. The right panel presents the percentage of respondents who answer either "major" or "severe". One aspect of vignettes in the public services domain pertains to the extent to which a vignette owner has to go through administrative barriers. When describing the owner who is required to make frequent trips to the capital to complete any administrative paperwork as in vignette 4, 43\% of respondents answer either "major" or "severe" difficulty. In contrast, less than $2 \%$ respondents answer "major" or "severe" when describing the owner who can complete the same administrative paperwork either in Yangon or online.

Another aspect of vignettes in the public service domain relates to costs and time it takes a vignette owner to acquire a public service. When describing vignette owner 1 , who is required to pay US\$ $1,200^{7}$ in registration fees, waits for two months, and has to go through 11 official procedures to have his new business formally registered, and vignette owner 9, who is required to pay US\$ $4,500^{8}$ in application fees for a construction permit and waits for 5 months for approval, 70\% of respondents answer "major" or "severe" for both.

Figure 4 lists the distributions of responses for electricity vignettes. As one would expect, number of hours of outage is positively associated with the percentage of respondents who answer either "major" or "severe". For instance, $87 \%$ of respondents answer either "major" or "severe" when rating vignettes 2 that describe a business that experiences 6 hours of outage on a daily basis. This compares with $93 \%$ for vignette 6 that describes a business sustaining 8 hours of outage daily.

\footnotetext{
${ }^{7}$ These statistics are based on the World Bank's Doing Business Survey. See http://www.doingbusiness.org/data/exploreeconomies/myanmar/\#dealing-with-construction-permits for more details on construction permit.

${ }^{8}$ These statistics are based on the World Bank's Doing Business Survey. See http://www.doingbusiness.org/data/exploreeconomies/myanmar/\#starting-a-business for more details on business registration.
} 
The scenario described in vignette 5 reflects electricity supplied to businesses located in the Yangon downtown areas, whereas that described in vignette 9 characterizes the best case. While electricity supply described in both vignettes are equally stable, there is a subtle difference in the pattern of responses between them. Specifically, in the lower tail of the scale, $14 \%$ of respondents answer "no difficulty" when describing vignette 5, which compares with $30 \%$ for vignette 9 . However, in the upper tail, just 3\% of respondents answer "severe" when describing vignette 5 , which compares with $11 \%$ for vignette 9 . This contradiction is due to the fact that responses for vignette 5 are heavily concentrated in the middle of the scale, while responses for vignette 9 are relatively more concentrated in the left tail of the scale, particularly the first response category (i.e. "no difficulty"), and become equally spread out in the upper three response categories (i.e. "moderate", "major", and "severe").

\section{d. Vignette Regressions}

I analyze the independent effects of vignette characteristics in multivariate analyses by creating variables representing individual characteristics and then regressing vignette evaluations on these variables. The following describe the variables entering each vignette regressions. Credit vignettes: (1) interest rate, (2) a dummy indicating if a loan is from a bank, (3) a dummy indicating if a loan is from a newly-established SME bank, (4) value of collateralized asset expressed as percentage of loan amount, (5) a dummy indicating if a collateralized asset is an apartment, (6) a dummy interacting bank loan dummy with apartment dummy, and (7) a dummy for vignette 12 that describes an owner who has no access to any credit.

Public services vignettes: (1) cost to acquire a public service (in 1,000 US\$), (2) days it takes to have a public service delivered, (3) number of official procedures involved to complete an administrative paperwork, (4) a dummy for vignette 3 that describes an owner who can complete an administrative paperwork in Yangon, (5) a dummy for vignette 4 that describes an owner who is required to make a trip to the capital to complete an administrative paperwork, (6) a dummy for vignette 5 that describes an owner who can complete an administrative paperwork online, (7) number of days it takes to have an invoice approved, and (8) number of official signatures required to have an invoice approved.

Electricity vignettes: (1) a dummy for vignette 1 that describes a business that just received a new connection under existing administrative procedures, (2) a dummy indicating if a business is located in an industrial zone, (3) total hours a business operates generator each day due to power 
outage or insufficient voltage, (4) a dummy indicating if a business has no access to electricity, (5) a dummy indicating if a business operates generator to mainly power air conditioning due to insufficient voltage, (6) a dummy indicating if application for a new connection is still pending, (7) a dummy indicating if a business experiences outage for an hour each day and operates without electricity during outages, and (8) a dummy indicating if a business rarely experiences power outages and insufficient voltage.

Table 8, Table 9, and Table 10 list the breakdowns of the characteristics present in the credit, public services, and electricity vignettes, respectively.

Table 11 presents results from 3 credit vignette regressions: (1) OLS, (2) Ordered logit, and (3) Logit, where I group "severe difficulty" and "major difficulty" into one category, and "moderate difficulty", "mild difficulty", and "no difficulty" into another category". One can see that the results across the 3 models are qualitatively similar. I will limit the discussions of the results to the OLS estimates in column 1 due to their easy interpretation.

The bank loan dummy is highly significant $(\mathrm{p}$-value $=0.000)$ and its effect size is large. Bank loans are on average rated 0.537 point higher on a 5-point scale (recall the scale runs from 1 being "no difficulty" to 5 being "severe difficulty"), relative to equivalent loans from friends/relatives. Interest rate is positively associated with evaluations and a one point increase in interest rate is associated with an increase in evaluation by 0.029 point. Based on this point estimate, the effect of bank loan is comparable to raising the interest rate by 19 percentage points. Respondents who did not apply for any bank loans in the past two years are asked the reasons for not applying. About $41 \%$ mention that they didn't understand or were not familiar with procedures for bank loans, or loan procedures were lengthy and complicated as primary reasons for not applying any bank loans, which could partially explain the large bank effect.

Despite its widespread appeal ${ }^{10}$ to a wide audience including government officials, the donor and business community, whether or not a loan is a SME bank loan has no significant effect on evaluations $(p$-value $=0.814)$ and its effect is negligible $(\beta=-0.032)$.

\footnotetext{
9The results are similar qualitatively if I instead group "severe difficulty", "major difficulty", and "moderate difficulty" into one group, and "mild difficulty" and "no difficulty" into another group.

${ }^{10}$ See the following for extensive news coverage about SME banks.

1.http://www.wsj.com/articles/myanmars-small-businesses-targeted-by-world-bank-loan-1410861135,

2.http:/www.irrawaddy.org/business/burma-boost-sme-access-capital-50mln-loan-singapore-vietnam.html,

3.http://ifcextapps.ifc.org/ifcext/Pressroom/IFCPressRoom.nsf/0/DA68A4369A7ED58185257D55002561CE?opend ocument
} 
Value of collateralized asset has no effects on evaluations ( $p$-value $=0.453$ ). In contrast, the type of collateral has significant impact ( $p$-value $=0.006)$, as suggested by the coefficient of the dummy interacting apartment dummy with bank dummy. In other words, a relaxation of collateral requirement (i.e. from land or house to apartment) is associated with a 0.301 point decrease in evaluations and its effect size is equivalent to reducing the interest by about 10 percentage points.

The coefficient for vignette 12 uniquely identifies the situation of vignette owner 12 and thus its coefficient represents the overall evaluation of that person as a whole. Its effect size is the largest ( $\beta=1.429$ that is equivalent to raising the interest by 49 percentage points) and highly significant $(\mathrm{p}$-value $=0.000)$.

Turning to vignette evaluations in the public services domain, the results in Table 12 indicate that every thousand dollars a vignette owner spends on acquiring a public service is associated with an increase in evaluations by 0.229 points on a 5 -point scale $(p$-value $=0.000)$. Improving bureaucratic efficiency is found to have large and significant impacts. Being able to complete administrative paperwork either in Yangon or online is associated with respectively a1.07 and 1.078 point ( $\mathrm{p}$-value $=0.000$ for both) decrease in evaluations, relative to having to travel to and complete the same paperwork in the capital city. These effects are roughly equivalent to reducing acquisition costs by approximately US\$4,700. Other measures of bureaucratic efficiency have expected signs and are significant. For instance, a reduction in one official procedure to complete administrative paperwork is associated with a US\$ 384 decrease in acquisition costs, and a one day delay to approve an invoice is associated with a US\$ 231 increase in acquisition costs.

Table 13 lists the effects of electricity vignette characteristics. An additional hour of outage is associated with an increase in evaluation by 0.153 points. Vignette 9 , whose coefficient uniquely identifies the evaluation of a business that rarely experiences outage and receives sufficient electrical voltage in a typical day, is rated on average 0.667 point lower. Vignette 5 that describes a business that has to operate a generator daily mainly to power air conditioners due to insufficient voltage is rated 0.665 point lower on average. That the effect size of vignette 5 is comparable to that of vignette 9 implies that if one could receive uninterrupted electricity each day, one should have no difficulty with electricity supply, regardless of whether the voltage is sufficient or not. As described earlier, $49 \%$ of the population lacks access to electricity and 
vignette 4 embodies this situation. Its effect on evaluations is found to be the largest (1.086; pvalue $=0.000)$ and is equivalent to cutting daily electricity supply by 7 hours.

It is well known that electricity supplied to industrial zones ${ }^{11}$ located in the Yangon areas is less stable and reliable, which is also supported by the data ${ }^{12}$. To assess if mere mentioning of industrial zone has any significant impacts on respondents' evaluations of vignettes, I include a dummy for industrial zone. However, the coefficient for industrial zone is insignificant ( $p$-value $=0.988$ ), suggesting that the general perception of electricity supply in industrial zones is not systematically different from that of non-industrial areas, after controlling for outage hours.

\section{THE THEORY OF VIGNETTES}

Let's first graphically illustrate the underlying intuition behind employing vignettes to address the identification issue associated with different respondents using different response scales, and then present a more formal statistical approach. Suppose we have two groups of business owners with different socioeconomic characteristics (say groups A and B) whose distribution of true but unobserved level of difficulty is presented in Figure 5. That the distribution of unobserved level of barrier to access to any given business environment domain for group A is situated to the left of group B suggests that, on average, individuals in group B face more barriers to access than those in group A.

Suppose individuals in these two groups also use different response scales if they are asked to rate their own difficulty on a 5 -point scale $(1=$ no difficulty, $2=$ mild, $3=$ moderate, 4 = major, $5=$ severe). In this particular example, those in group B are less likely to say "major" or "severe", relative to a comparable person in group A. As a result, the frequency distribution of subjective responses in the two groups would lead us to the incorrect conclusion that respondents in group A face more difficulty than those in group B - the exact opposite holds true in this hypothetical example. Correcting for such differences in reporting behavior ("differential item functioning" (DIF), in the terminology of King et al. (2004)) is essential for comparing the actual barrier to access in the two groups.

\footnotetext{
${ }^{11}$ There are 20 industrial zones spread across Yangon. See http://myanmarindustries.org/index.php/home-2/38myanmar-industries/industrial-zones/239-industrial-zones-yangon for a complete list.

${ }^{12}$ For industrial zones, the average number of outages in a month is 19 , compared with 11 for non-industrial areas.
} 
The use of anchoring vignettes can help achieve this correction. The vignette owners presented to both groups face the same level of barrier to access by construction. For instance, we can ask respondents to evaluate the barrier to access of a vignette owner whose actual barrier is represented by the broken line in Figure 5. Respondents in group A will answer "major", whereas those in group B will answer "no difficulty." Since the actual barrier of the vignette owner is the same for both groups, the difference in the vignette evaluations represents the effect of DIF. Thus, the use of anchoring vignettes can help identify and account for differences in response scales. Using the scales in one of the groups as the benchmark, the distribution of evaluations in the other group can be adjusted using that benchmark. The adjusted distribution can then be compared correctly and the correction brings the two groups on the same scale.

\section{ECONOMETRIC MODEL}

I will now present a more formal statistic model explaining self-evaluations, and vignette evaluations.

Self-reports will be modelled as a function of an underlying latent index reflecting actual difficulty, as well as of individual-specific thresholds. Vignette evaluations are reported on the same categorical scale as the self-evaluations.

The vignette approach rests on two critical assumptions: Vignette Equivalence (VE) and Response Consistency (RC). VE stipulates that respondents' characteristics have no influence on how they interpret vignettes, an assumption which could well be open to criticism in situations where respondents rely on their personal experiences to infer missing information in the vignettes. RC means respondents use the same categorical scales when evaluating themselves as when evaluating the vignette person. For the purpose of this analysis, I take these two assumptions as given.

The detailed econometric specifications are given by the following:

\section{a. Self-Evaluations}

The subjective measure of each of the three business domains $(t) Y_{s t i}$ for respondent $i$ has a subjective response scale from 1 being "no difficulty" to 5 being "severely difficult". The self-reports $Y_{s t i}$ are assumed to be driven by an underlying and unobserved continuous latent 
index $Y_{s t i}^{*}$ reflecting actual barrier to access in business domain $t$ for individual $i$, which is modelled as

$$
\begin{aligned}
& Y_{s i t}^{*}=X_{i} \beta_{s t}+\xi_{s i t} \\
& Y_{s i t}=j \quad \tau_{i t}^{j-1}<Y_{s i t}^{*} \leq \tau_{i t}^{j}, j=1,2,3,4,5
\end{aligned}
$$

Hence $X_{i}$ is a set of observed respondent and business characteristics. Specifically, $X_{i}$ include (1) age (19-39, 40-50, 61-64, 65+), (2) education (low, medium, high education) (3) ethnicity (minorities, Burmese), (4) gender (male, female), (5) if a respondent is owner, (6) if a business is small-size, (7) if a business is selling goods/service to the government, and (8) if a business is located in an industrial zone. $\xi_{\text {sit }}$ may be interpreted as unobserved heterogeneity combined with idiosyncratic noise affecting the subjective evaluations. I will assume that $\xi_{\text {sit }}$ is normally distributed with mean zero and variance normalized to $\tau_{\xi t}^{2}=1$, independent of $X_{i}$. The thresholds $\tau_{i t}^{j}$ between the categories are given by $\mu_{i t} \sim N\left(0, \sigma_{u t}^{2}\right), \mu_{i t}$ is independent of $X_{i t}$ and $\xi_{s i t}$

The fact that the thresholds vary across respondents represents DIF. The covariates entering $X_{i t}$ in equation 3 are assumed to be the same as those entering equation 1 explaining self-reports. The term $\mu_{i t}$ introduces an unobserved heterogeneity term (modeled as a random individual effect) in the response scale. Using subjective self-reports alone, parameters $\beta_{s t}$ and $\gamma_{s t}^{1}$ are not separately identified, instead their difference is identified $\left(\gamma_{s t}^{j}\right.$ for $j>1$ will still be identified). In particular, using only self-assessments, we are not able to disentangle the selfreports into the systematic part that is due to differences in true barrier to access $\beta_{s t}$ in business domain $t$ and a part that is due to heterogeneity in reporting behavior $\left(\gamma_{s t}^{j}, j=1,2,3,4\right)$. For instance, business owners with different socioeconomic characteristics can simultaneously differ on actual level of access as well as the scales on which they report their barrier. Hence, selfreports of level of access are not sufficient to identify actual barriers across socioeconomic groups as shown in Figure 5. The vignettes will be employed to separately identify $\beta_{s t}$ and $\gamma_{s t}^{1}$. 


\section{b. Vignette Evaluations}

Vignette evaluations have the same response scale categories as the subjective measure. The evaluations $Y_{v i t}$ of vignette $v=1, \ldots . ., L ; t=1,2,3$ are modelled using similar ordered response equations:

$$
Y_{v i t}^{*}=\omega_{v t}+\grave{o}_{v i t}
$$

$Y_{v i t}^{*}=j$ if $\tau_{i t}^{j-1}<Y_{v i t}^{*} \leq \tau_{i t}^{j}, j=1,2,3,4,5$

$\grave{o}_{v i t} \sim N\left(0, \sigma_{t}^{2}\right) ; \grave{o}_{v i t}$ is independent of $\xi_{\text {sit }}$ and $X_{i t}$

Respondent characteristics $X_{i}$ are not included in (4) - this is the maintained assumption of vignette equivalence (VE). If respondents are given the same vignette descriptions and there is no ambiguity in interpreting the information presented, there is no reason why different respondents should give us systematically different responses except for DIF. The thresholds are modeled in a similar way as those in the self-report equation, but with different parameters.

$$
\tau_{v i t}^{0}=-\infty, \tau_{v i t}^{5}=+\infty, \tau_{v i t}^{1}=\gamma_{v t}^{1} X_{i t}+u_{i t}, \tau_{v i t}^{j}=\tau_{v i t}^{j-1}+\exp \left(\gamma_{v t}^{j} X_{i t}\right), j=2, \ldots, 4 ; t=1,2,3
$$

The standard Hopit model (see, e.g., King el al, 2004) assumes response consistency: $\tau_{s i t}^{1}=\tau_{v i t}^{1}, j=1, \ldots, 4 ; i=1, \ldots, N$. With this assumption, it is clear how vignette evaluations can be used to separately identified $\beta_{s}$ and $\gamma_{s t}^{j}=\gamma_{v t}^{j}(j=1,2,3,4 ; t=1,2,3)$. From the vignette evaluations alone, $\gamma_{v t}$ can be identified (up to the usual normalization of scale and location), and $\beta_{s}$ can then be identified from the self-assessments. Thus, the vignettes can be used to solve the identification problem due to DIF under the assumption of response consistency (RC) and vignette equivalence (VE).

Using maximum likelihood estimation, I maximize the following likelihood function consisting of a self-evaluation part (first part) and a vignette evaluation part (second part):

$$
L\left(\beta, \gamma, \omega, \alpha \mid Y_{s}, Y_{v}\right)=L\left(\beta, \gamma \mid Y_{s}\right) * L\left(\omega, \alpha \mid Y_{v}\right)
$$

Which is specified as

$$
\int \prod_{k=1}^{k=5} p\left(y_{s i t}=k \mid \phi, \mu_{i t}\right)^{I\left(y_{s i t}=k\right)} \prod_{v=1}^{v=3} \prod_{m=1}^{m=5} p\left(y_{v i t}=m \mid \phi, \mu_{i t}\right)^{I\left(y_{i t i}=m\right)} f\left(u_{i t}\right) d u_{i t}
$$

Where $\phi$ is a vector of parameters to be estimated and $I($.$) is an indicator function. The$ unconditional likelihood contribution of respondent $i$ can be computed numerically as an expectation over $\mathrm{u}_{\mathrm{i}}$. 


\section{RESULTS}

This section presents the estimated coefficients for model not accounting for DIF (i.e., Ordered probit) and model accounting for DIF (i.e., CHOPIT), and discusses the differences in estimated coefficients between the two models that are due to differences in response scales. Log likelihood ratio test is performed to judge the fitness of the models, with the no DIF model (more restrictive model) being nested in the DIF model (more general model).

\section{a. Credit}

Table 14 lists the parameter estimates for the equations explaining self-reports of barriers to access to credit. The second column presents parameter estimates in the no DIF case using ordered probit model, while the third column lists parameter estimates adjusted for DIF, and the last 4 columns list estimates for the threshold parameters.

According to the no DIF model, the 51-64 and 65+ age groups experience fewer barriers to access (the reference group being 19-39). Their coefficients are statistically significant, and the age difference is more pronounced for $65+$. Respondents representing small-size businesses are more likely to self-report that access to credit is more difficult for them ( $p$-value $=0.021$ ). Similarly, respondents who are owners and representing businesses located in industrial zone are positively associated with barrier to access to credit and their coefficients are significant. However, it is unclear from the no DIF model whether these significant differences reflect the true underlying differences or differences in response scales across subgroups, or both.

Let's now examine how the coefficients change in significance as well as in sign as we allow the threshold parameters to vary across subgroups and account for DIF. In the DIF model, we observe changes to the estimated coefficients in terms of statistical significance and effect sizes that are contrary to what the no DIF model shows. For instance, the coefficient for $65+$ age group that is negative and highly significant in the no DIF model has become insignificant, suggesting that the earlier difference found for this group in the no DIF model is due to a different reporting style used by $65+$ age group.

Allowing for the threshold parameters to vary across subgroups is key to explaining why findings differ between the no DIF model and DIF model. This difference in reporting style used by the age $65+$ is revealed by the positive values of all threshold parameters demarcating the 5 response categories (last 4 columns in Table 14) that trigger a shift in the response scales to the 
right for this group (call it high thresholds). Consequently, what 65+ consider "no difficulty" is often considered "mild difficulty" by others, and the difference in the first cut-point exerts similar effects on higher cut-points (what they consider "major" is often considered "severe" by others, etc.).

The coefficient for small-size business continues to be positive and significant in the DIF as does in the no DIF model and its effect size change little. This is consistent with the data indicating that only $13 \%$ of small-size businesses have received any bank loans since they were established, compared with $28 \%$ for medium-size businesses.

Whether a respondent is a business owner or not makes a difference when it comes to self-reports of business financial matters. Specifically, the negative values of the first three threshold parameters underscore a different and more stringent reporting style (call it low thresholds) that business owners use when self-reporting their level of access to credit. Their coefficient, which is positive and significant in the no DIF model, has become insignificant when applying DIF correction. This finding is particularly relevant to enterprise surveys in which a majority of respondents tend to be non-owners.

The likelihood ratio test fails to reject CHOPIT model against ordered probit model (Pvalue $=1.000)$, indicating the model accounting for DIF fits the data better.

\section{b. Electricity}

Table 15 presents a comparison of no DIF and DIF models regressing self-reports of difficulty in access to electricity on subgroup dummies. The results reveal that DIF continues to persist, but to a lesser extent. Without DIF, small-size businesses are estimated to be less likely and businesses located in industrial zones are more likely to self-report that access to electricity is difficult for them and these differences are statistically significance ( $p$-value $=0.000$ for both). With DIF, their coefficients are still significant, which is consistent with the more objective measures of electricity supply indicating that on average (1) small-size businesses experience 12 outages in a typical month, which compares with 14 for medium-size businesses, and (2) businesses located in industrial zones experience 19 outages in a typical month, which compares with 11 for businesses located in non-industrial zones. Changes in their effect sizes (i.e. from 0.272 in no DIF to -0.195 in DIF for small businesses; from 0.468 in no DIF to 0.555 in DIF for businesses in industrial zone) reflect corrections for DIF. DIF model doesn't get rejected against 
no DIF model $(\mathrm{P}$-value $=1.000)$, suggesting that it has more explanatory power then the no DIF model.

\section{c. Public services}

Table 16 lists parameter estimates for equations explaining self-reports of barriers to access to public services. The results show that self-reports of access to public services are most affected by DIF, compared with those of credit and electricity. This is consistent with findings from prior studies suggesting that self-reports of sensitive issues such as disability benefits (Kapteyn et al., 2007), self-rated health (Grol-Prokopczyk et al., 2011), health disparity (Banks et al., 2009), and drinking behavior (Soest et al., 2011) are more likely to be affected by DIF.

Without DIF, older age groups, particularly 51-64 and 65+, and the small-size group are less likely to report that access to public services is difficulty for them. However, estimates from the DIF model indicate that these differences are due to the more optimistic reporting styles used by these groups. For instance, what the 19-39 age group calls "major" is frequently called "moderate" by $65+$ age group $\left(\operatorname{Ln}\left(\tau_{3}-\tau_{2}\right)=-0.237\right)$, and what the 19-39 age group calls "severe" is often called "major" by $65+$ age group $\left(\operatorname{Ln}\left(\tau_{4}-\tau_{3}\right)=-0.311\right)$. The more optimistic reporting styles used by 51-64 and small business groups are represented by a shift to the right in the first three thresholds (i.e. high thresholds).

Highly educated individuals, males, and businesses selling goods/services to the government are more likely to report that access to public services is difficult, and their differences are highly significant ( $p$-value $=0.000$ for all). In the DIF model, these differences are still significant ( $\mathrm{p}$-values $=0.000$ for all as well). What the low education group considers "major" is considered "severe" by medium and high education groups $\left(\operatorname{Ln}\left(\tau_{4}-\tau_{3}\right)=-0.136\right.$ for medium education group, and $\operatorname{Ln}\left(\tau_{4}-\tau_{3}\right)=-0.120$ for high education group). As for gender differences in reporting style, compared with females, males are more likely to choose "moderate" over "mild" $\left(\operatorname{Ln}\left(\tau_{2}-\tau_{1}\right)=-0.243\right.$; p-value $\left.=0.001\right)$, and "severe" over "major" (Ln $\left(\tau_{4}-\tau_{3}\right)=-0.165 ; \mathrm{p}$-value $\left.=0.02\right)$. Businesses selling goods and services to the government apply a more stringent reporting standard (low thresholds) when rating the performance of government agencies. They are less likely to use the labels "no difficulty" and "minor", and more likely to apply the labels "moderate" and "major", as indicated by the negative values of the first two thresholds and the positive values of the last two thresholds. Similarly, ethnic minorities tend to hold government agencies to a higher reporting standard, frequently using the 
label "major", while parsimoniously using "no difficulty", "minor", and "moderate" $\left(\tau_{1}=-0.095\right.$; $\left.\operatorname{Ln}\left(\tau_{2}-\tau_{1}\right)=-0.014 ; \operatorname{Ln}\left(\tau_{3}-\tau_{2}\right)=-0.003 ; \operatorname{Ln}\left(\tau_{4}-\tau_{3}\right)=0.146\right)$. Likelihood ratio test fails to reject DIF model $(\mathrm{P}$-value $=1.000)$ against ordered porbit, suggesting that DIF model explains the outcome better, compared with naïve ordered probit model.

My results suggest that empirical models explaining business outcomes (such as profit, growth) and using self-reports of business environment as explanatory variables can lead to wrong conclusions if different styles of reporting systematically vary with other explanatory variables. As indicated by likelihood ratio test statistics, models accounting for DIF fit the data better.

\section{CONCLUSION}

Subjective measures of business environment have been used in many cross-country studies to generate country reports, which have the potential for influencing policy decisions. However, comparability of these measures across individuals within a country or across countries is hampered by the fact that different individuals may use different response scales. Anchoring vignettes offer the potential to apply corrections to self-reported measures affected by DIF. In this paper, I report findings from a study I conducted in the city of Yangon, Myanmar, focusing on three critical areas of the business environment: (1) access to credit, (2) access to public services, and (3) access to electricity. In addition to uncovering DIF, anchoring vignettes also help identify major barriers to access to important services facing the business community in Myanmar. Despite its widespread use in many important studies, the anchoring vignette methodology has not been applied to the business environment research before.

My results suggest that self-reports of business environment are affected by DIF.

In the access to credit domain, respondents in the age 65+ group are on average found to have higher thresholds and thus are less likely to report that they are credit constrained. In contrast, small business group are on average found to have lower thresholds and thus are more likely to report that they are credit constrained. My results also indicate that respondents who are owners use a very high reporting standard, often using the labels "major" or "severe". Compared to access to credit, DIF tends to be less of an issue with self-reported measures of access to electricity. Small-size businesses are found to use high thresholds. In contrast, businesses located in industrial zones are found to use low thresholds. After correcting for DIF, their coefficients 
still retain their statistical significance, which is consistent with their more objective measures of access to electricity.

My results show that, among the three business domains considered in this analysis, selfreported measures of access to public service are most affected by DIF. Older age groups, in particular $65+$, are found to be more optimistic (have high thresholds) when reporting their access to public services and their estimated effects disappear after applying adjustments. In contrast, higher education groups and males tend to apply higher standards (have low thresholds). Similarly, businesses selling goods and services to the government apply a more stringent reporting standard when rating the performance of government agencies. Ethnic minorities are also found to apply a higher reporting standard, frequently using the label "major", while parsimoniously using "no difficulty", "minor", and "moderate."

My results imply that empirical models explaining business outcomes (i.e. profit, growth, innovation) and using self-reported measures of the various aspects of the business environment as explanatory variables, among others, can result in biased estimates if the measurement scales vary systematically with other explanatory variables. Without further information, one can't know whether the differences in firm outcomes are due to differences in business environment or partly reflect differences in reporting styles as my results indicate. I demonstrate in this analysis that vignettes offer an opportunity to detect such scale differences and correct them.

In addition to uncovering reporting differences, vignettes help us identify key barriers to access to credit, electricity, and public services facing the Myanmar business community, which will in turn better inform policy decisions. My results show that having access to SME loans has no impact on their evaluation compared to other bank loans, despite their widespread appeal among donors, the business community, and policy makers. The policy implication is that potential barriers to implementation and take-up of the SME loan program need to be identified and addressed if it is to fully achieve its intended effects. In addition, policy makers should consider scaling up the program (instead of a full-scale implementation) that will allow for improving the program design over time. My results imply that a policy option permitting assets (other than land or house or both) to be used as collateral has the potential for improving access to bank loans. I also find that access to bank loans has an effect equivalent to increasing the interest rate by 19 percentage points. When asked the primary reason for not applying for bank loans, $41 \%$ of respondents mention they didn't understand or were not familiar with procedures 
for bank loans, or loan procedures were lengthy and complicated. These findings suggest that improving access to loan information, enhancing transparency in the banking system, and simplifying loan procedures offer another area of policy intervention for improving access. In terms of access to public services, my results indicate that streamlining routine administrative paperwork to be completed online or in Yangon (compared to the need to travel to the capital city) results in a cost saving to a business by US $\$ 4,700$ on average.

\section{a. Suggestions for future research}

Not only can response scales vary among individuals within a country as my results have demonstrated, but they could also vary among individuals across countries. Let's revisit the hypothetical example in Figure 5 introduced earlier. The distribution of unobserved level of access for group A is situated to the left of group B, suggesting that, on average, individuals in country B face more barriers to access than those in country A.

Suppose individuals in these two countries also use different response scales if they are asked to rate their own difficulty on a 5-point scale $(1=$ no difficulty, $2=$ mild, $3=$ moderate, 4 = major, 5 = severe). In this particular example, those in country B are less likely to say "major" or "severe", relative to a comparable person in country A. As a result, the frequency distribution of subjective responses in the two groups would lead us to the incorrect conclusion that people in country A face more difficulty than those in country B - the exact opposite holds true in this hypothetical example.

For a more concrete example, let's assume that the distribution in A represents access to public service for businesses in Singapore - a country well known for its stellar records on administrative and bureaucracy efficiency - and the distribution in B represents access to public service for businesses in Myanmar - a country that ranks very low on all measures of bureaucratic and administrative efficiency ${ }^{13}$. Let's suppose that respondents in these two countries are asked to evaluate vignette 2 in public services domain whose difficulty is presented by the broken line in Figure 5. The exact text of vignette 2 is the following:

Vignette 2 (Public services): It costs Ma Kay Thi US\$ 1,200 in registration fees, took her 3 days, and involved 2 official procedures to formally register her business.

\footnotetext{
${ }^{13}$ See http://www.doingbusiness.org/contributors/doing-business/myanmar for the latest ranking.
} 
Being inured to the fact that formal registration of a new business can be done online within a day costing less than US\$ $230^{14}$, respondents in country A (i.e. Singapore) will immediately answer "major", whereas those in country B (i.e. Myanmar), being accustomed to the extreme difficulty associated with formally registering a new businesses in the past, will answer "no difficulty". Since the actual difficulty of the vignette owner is the same for both countries, the differences in evaluations represent differences in response scales between respondents in the two countries. Thus, the use of anchoring vignettes can help identify and account for such differences. Using the scales in one country as the benchmark, the distribution of evaluations in the other country can be adjusted using that benchmark. The adjusted distribution can then be compared correctly and the correction brings the two countries on the same scale.

Given vast differences in norms, culture, institutions, and level of development across countries, the potential for individuals in different countries using different response scales is high. Many studies involving international collaboration such as Program for International Student Assessment (PISA) (http://www.oecd.org/pisa/) and Global Aging and Retirement Study (https://www.g2aging.org/) have already demonstrated the usefulness of vignettes in addressing DIF. Thus, including vignettes in enterprise surveys and testing their validity offer a promising area of future research in the study of business environment for enhancing data comparability.

\footnotetext{
${ }^{14} \mathrm{http} / / /$ www.doingbusiness.org/data/exploreeconomies/singapore/starting-a-business
} 
Table 1: Sample Summary Statistics

\begin{tabular}{|c|c|c|c|c|c|}
\hline & $\mathrm{N}$ & Mean & S.D. & Min & Max \\
\hline \multicolumn{6}{|l|}{ Respondent Characteristics } \\
\hline Married & 1004 & 0.80 & 0.40 & 0 & 1 \\
\hline Male & 1004 & 0.74 & 0.44 & 0 & 1 \\
\hline Low education (high school and vocational training) & 1004 & 0.31 & 0.46 & 0 & 1 \\
\hline Medium education (bachelor degree) & 1004 & 0.59 & 0.49 & 0 & 1 \\
\hline High education (advanced and professional degree) & 1004 & 0.09 & 0.29 & 0 & 1 \\
\hline Age group (19-39) & 1004 & 0.36 & 0.48 & 0 & 1 \\
\hline Age group (40-50) & 1004 & 0.36 & 0.48 & 0 & 1 \\
\hline Age group (51-64) & 1004 & 0.24 & 0.43 & 0 & 1 \\
\hline Age group (65 plus) & 1004 & 0.05 & 0.21 & 0 & 1 \\
\hline If respondent is owner & 1004 & 0.86 & 0.35 & 0 & 1 \\
\hline If respondent is ethnic Burmese & 1003 & 0.61 & 0.49 & 0 & 1 \\
\hline If respondent is ethnic minority & 1004 & 0.16 & 0.36 & 0 & 1 \\
\hline If respondent is ethnic Chinese & 1004 & 0.12 & 0.32 & 0 & 1 \\
\hline If respondent is ethnic Indian & 1004 & 0.08 & 0.27 & 0 & 1 \\
\hline If respondents actively involved in the business operations| owners & 862 & 0.99 & 0.09 & 0 & 1 \\
\hline If respondent grew up in a family owning businesses & 987 & 0.51 & 0.50 & 0 & 1 \\
\hline If father owned and managed family business & 1002 & 0.51 & 0.50 & 0 & 1 \\
\hline If respondent owned a business prior to establishing current business & 1001 & 0.35 & 0.48 & 0 & 1 \\
\hline Prior business produced goods and services as the current businesses & 342 & 0.34 & 0.48 & 0 & 1 \\
\hline If respondent had prior work experience & 1003 & 0.73 & 0.44 & 0 & 1 \\
\hline $\begin{array}{l}\text { If work experience accumulated in the same industry | had prior work } \\
\text { experience }\end{array}$ & 730 & 0.54 & 0.50 & 0 & 1 \\
\hline Years of work experience before establishing current business & 726 & 11.92 & 9.12 & 0 & 44 \\
\hline \multicolumn{6}{|l|}{ Business Characteristics } \\
\hline If business is small-sized (current employees $<20$ ) & 1004 & 0.73 & 0.44 & 0 & 1 \\
\hline If business is in construction industry & 1004 & 0.05 & 0.21 & 0 & 1 \\
\hline If business is in service industry & 1004 & 0.24 & 0.42 & 0 & 1 \\
\hline If business is in manufacturing industry & 1004 & 0.24 & 0.43 & 0 & 1 \\
\hline If business is in trading industry & 1004 & 0.36 & 0.48 & 0 & 1 \\
\hline If business is located in an industrial zone & 1002 & 0.21 & 0.41 & 0 & 1 \\
\hline If business is exporting goods or services & 993 & 0.09 & 0.29 & 0 & 1 \\
\hline $\begin{array}{l}\text { If business sold goods or services to the government in the past two } \\
\text { years }\end{array}$ & 974 & 0.16 & 0.36 & 0 & 1 \\
\hline Years business has been operational & 1003 & 14.20 & 10.9 & 0 & 50 \\
\hline If owner is ethnic Burmese| respondent is owner & 862 & 0.59 & 0.49 & 0 & 1 \\
\hline If owner is ethnic Chinese| respondent is owner & 863 & 0.13 & 0.33 & 0 & 1 \\
\hline If owner is ethnic Indian| respondent is owner & 863 & 0.09 & 0.28 & 0 & 1 \\
\hline If owner is ethnic minorities| respondent is owner & 863 & 0.15 & 0.36 & 0 & 1 \\
\hline \multicolumn{6}{|l|}{ Loan Variables } \\
\hline Personal or family savings, or assets as startup capital & 992 & 0.89 & 0.31 & 0 & 1 \\
\hline Pooling funds among business partners or friends as startup capital & 992 & 0.10 & 0.30 & 0 & 1 \\
\hline Loans from friends, relatives, or business partners as startup capital & 992 & 0.07 & 0.25 & 0 & 1 \\
\hline Loans from banks as startup capital & 992 & 0.05 & 0.21 & 0 & 1 \\
\hline Startup capital not required because the business was inherited & 992 & 0.08 & 0.28 & 0 & 1 \\
\hline $\begin{array}{l}\text { Used retained profits and business assets to finance expansion in the } \\
\text { past two years }\end{array}$ & 989 & 0.69 & 0.46 & 0 & 1 \\
\hline $\begin{array}{l}\text { Used personal/family saving(s) of owners and to finance expansion in } \\
\text { the past two years }\end{array}$ & 989 & 0.52 & 0.50 & 0 & 1 \\
\hline
\end{tabular}


Submitted loan applications in the past two years

Number of bank loan applications submitted in the past 2 years|

submitted applications

If loans applications were approved | submitted applications

Number of bank loans approved | submitted applications

Bank loans amount (1000 US\$)

Number of collateral required | received bank loans

Value of collateral | received bank loans (million US\$)

Bank loan repayment timeframe (months)

Annual bank loan interest (\%)

To finance business expansion

To finance acquisition of new capitals/improving existing capitals

To finance regular business operations

To pay back existing debt

If business has ever received bank loans since establishing

Total bank loans received since establishing | received bank loans

Didn't understand or not familiar with the procedures to apply for bank loans

Bank loan procedures were lengthy and complicated

Didn't have the collateral banks required

Not enough collateral value

Didn't need a bank loan

If business tried to get any loans from relatives/friends in the past 2 years

Number of loans business trying to get from friends/relatives in the past

2 years

Number of loans business received from friends/relatives in the past 2 years

Loan amount from friends/relatives (1,000 US\$)

Annual interest rate for loans received from friends/relatives in the past 2 years $(\%)$

\section{Public Service Variables}

If respondent made any business related trips to the capital city in the past 6 months

Number of business trips to the capital city in the past 6 months| made any trips

Number of days each trip lasted $\mid$ made any trips

Average cost per trip (US\$) | made any trips

Have a branch office in the capital

\section{Electricity Variables}

If business applied for new electricity connection in the past 12 months

Number of days it took to get new electricity connection

If business was required to buy a transformer with the new electricity connection

Cost of new electricity connection including transformer (1000 US\$)

If business experienced any power outage in a typical month in 2013

Number of outages experienced in a typical month in 2013 (all)

Number of outages experienced in a typical month in 2013 (nonindustrial)

Number of outages experienced in a typical month in 2013 (industrial)

Hours each outage lasted

If business owns a generator

\begin{tabular}{|c|c|c|c|c|}
\hline 994 & 0.15 & 0.36 & 0 & 1 \\
\hline 153 & 1.44 & .65 & 1 & 4 \\
\hline 153 & 0.93 & 0.26 & 0 & 1 \\
\hline 153 & 1.28 & 0.69 & 0 & 4 \\
\hline 138 & 271 & 412 & 6 & 2500 \\
\hline 133 & 1.28 & 0.58 & 1 & 4 \\
\hline 135 & 1.45 & 4.61 & 0 & 50 \\
\hline 137 & 11.82 & 13.50 & 0 & 98 \\
\hline 137 & 12.83 & 10.76 & 0 & 98 \\
\hline 136 & 0.76 & 0.43 & 0 & 1 \\
\hline 136 & 0.29 & 0.45 & 0 & 1 \\
\hline 136 & 0.21 & 0.41 & 0 & 1 \\
\hline 136 & 0.02 & 0.15 & 0 & 1 \\
\hline 974 & 0.17 & 0.38 & 0 & 1 \\
\hline 158 & 3.16 & 4.01 & 0 & 22 \\
\hline 797 & 0.15 & 0.36 & 0 & 1 \\
\hline 797 & 0.26 & 0.44 & 0 & 1 \\
\hline 797 & 0.12 & 0.32 & 0 & 1 \\
\hline 797 & 0.07 & 0.25 & 0 & 1 \\
\hline 797 & 0.65 & 0.48 & 0 & 1 \\
\hline 990 & 0.23 & 0.42 & 0 & 1 \\
\hline 224 & 4.50 & 6.17 & 0 & 66 \\
\hline 221 & 4.19 & 5.89 & 0 & 60 \\
\hline 207 & 84 & 211 & 0.50 & 2,000 \\
\hline 206 & 38.64 & 7.32 & 0 & 97 \\
\hline 1003 & 0.20 & 0.4 & 0 & 1 \\
\hline 201 & 5.84 & 7.45 & 1 & 60 \\
\hline 196 & 2.49 & 1.95 & 1 & 20 \\
\hline 195 & 189.74 & 100.5 & 100 & 600 \\
\hline 998 & .04 & .18 & 0 & 1 \\
\hline 1002 & 0.08 & 0.26 & 0 & 1 \\
\hline 61 & 48.48 & 58.29 & 1 & 360 \\
\hline 61 & 0.41 & 0.50 & 0 & 1 \\
\hline 52 & 21 & 30 & 0 & 100 \\
\hline 1003 & 0.97 & 0.17 & 0 & 1 \\
\hline 904 & 12.85 & 16.36 & 1 & 100 \\
\hline 716 & 11.30 & 14.1 & 1 & 99 \\
\hline 188 & 19.00 & 22.0 & 1 & 100 \\
\hline 916 & 3.31 & 5.54 & 1 & 48 \\
\hline 999 & 0.70 & 0.46 & 0 & 1 \\
\hline
\end{tabular}


Figure 1: Top Constraint by Business Domain

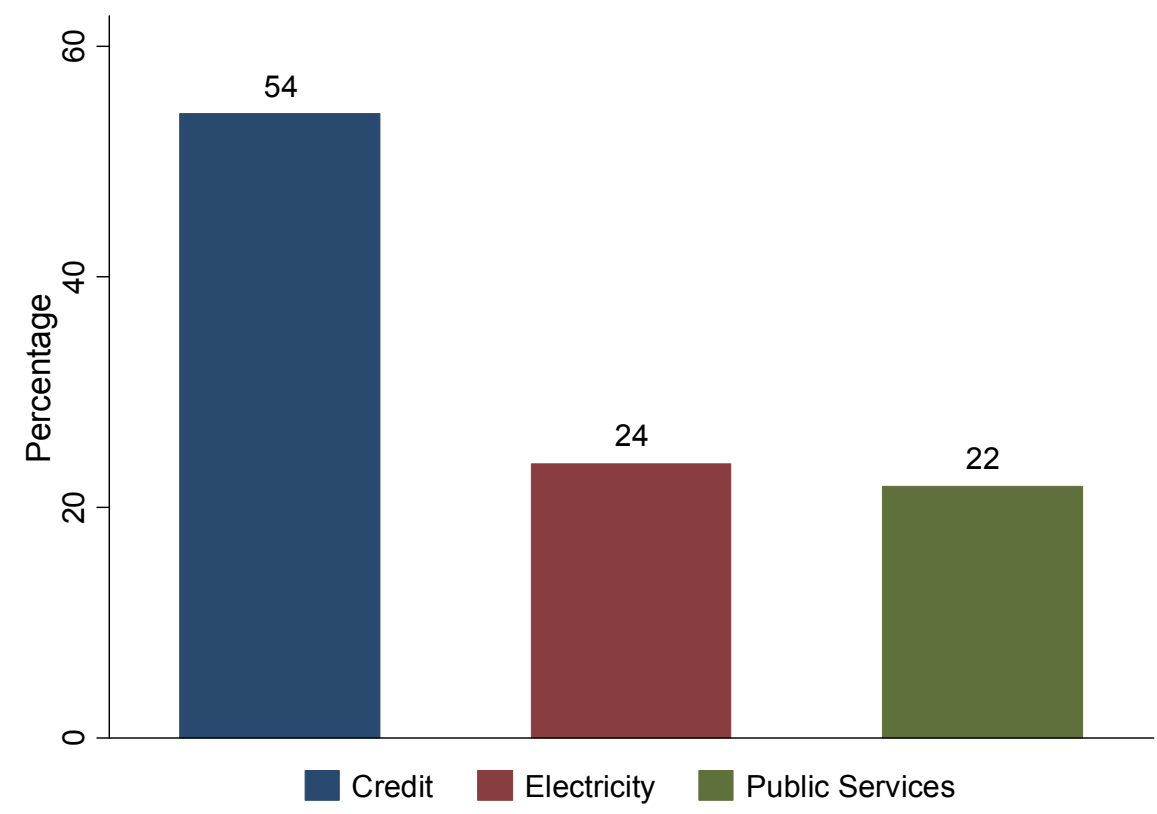

Table 2: Dependent Variable: Credit, Electricity, and Public Service Is Ranked First; Independent Variables: Self-Reports Of Difficulty on a 5-Point Scale

\begin{tabular}{llll}
\hline \hline & Credit & Electricity & Public Services \\
\hline Self-reports of difficulty (credit) & 0.099 & -0.054 & -0.044 \\
Self-reports of difficulty (electricity) & {$[0.013]^{* * *}$} & {$[0.011]^{* * *}$} & {$[0.011]^{* * *}$} \\
& -0.069 & 0.118 & -0.050 \\
Self-reports of difficulty (public services) & {$[0.013]^{* * *}$} & {$[0.011]^{* * *}$} & {$[0.011]^{* * *}$} \\
& -0.062 & -0.061 & 0.124 \\
Constant & {$[0.015]^{* * *}$} & {$[0.013]^{* * *}$} & {$[0.012]^{* * *}$} \\
& 0.640 & 0.184 & 0.173 \\
$\mathrm{~N}$ & {$[0.048]^{* * *}$} & {$[0.040]^{* * *}$} & {$[0.039]^{* * *}$} \\
$\mathrm{R}-$ Squared & 945 & 945 & 945 \\
\hline \hline Standard errors are in brackets. * & 0.092 & 0.131 & 0.105 \\
\hline
\end{tabular}


Table 3: Dependent Variable: Credit, Electricity, and Public Services Is Ranked First

\begin{tabular}{llll}
\hline \hline & Credit & Electricity & Public Services \\
\hline Age (40-50) & -0.031 & 0.076 & -0.034 \\
Age(51-64) & {$[0.038]$} & {$[0.032]^{* *}$} & {$[0.032]$} \\
& -0.027 & 0.061 & -0.015 \\
Age(65+) & {$[0.043]$} & {$[0.036]^{*}$} & {$[0.035]$} \\
& -0.171 & 0.182 & -0.002 \\
Medium education & {$[0.079]^{* *}$} & {$[0.066]^{* * *}$} & {$[0.066]$} \\
& -0.063 & -0.007 & 0.073 \\
High education & {$[0.036]^{*}$} & {$[0.030]$} & {$[0.030]^{* *}$} \\
Ethnic Burmese & -0.140 & -0.024 & 0.144 \\
& {$[0.060]^{* *}$} & {$[0.050]$} & {$[0.050]^{* * *}$} \\
Male & -0.027 & 0.011 & 0.017 \\
& {$[0.033]$} & {$[0.028]$} & {$[0.027]$} \\
Small-size business & -0.033 & -0.003 & 0.039 \\
Selling goods or services to government & {$[0.037]$} & {$[0.031]$} & {$[0.031]$} \\
& 0.020 & -0.071 & 0.060 \\
If respondent is owner & {$[0.038]$} & {$[0.032]^{* *}$} & {$[0.031]^{*}$} \\
Located in an industrial zone & 0.022 & -0.105 & 0.080 \\
& {$[0.042]$} & {$[0.035]^{* * *}$} & {$[0.035]^{* *}$} \\
Constant & 0.138 & -0.100 & -0.027 \\
& {$[0.048]^{* * *}$} & {$[0.040]^{* *}$} & {$[0.040]$} \\
\hline $\mathrm{N}$ & -0.110 & 0.176 & -0.075 \\
R-squared & {$[0.040]^{* * *}$} & {$[0.034]^{* * *}$} & {$[0.034]^{* *}$} \\
\hline \hline
\end{tabular}

Standard errors are in brackets. *significant at $10 \%$ level, ** significant at $5 \%$ level, and *** significant at $1 \%$ level. 
Table 4: Variations in Credit Vignettes

\begin{tabular}{|c|c|c|c|c|c|c|}
\hline Vignette & Loan amount (US\$) & $\begin{array}{c}\text { Annual interest } \\
\text { rate }(\%)\end{array}$ & Source of loan & $\begin{array}{c}\text { If loan requires } \\
\text { collateral }\end{array}$ & $\begin{array}{c}\text { Type of collateral } \\
\text { required }\end{array}$ & $\begin{array}{c}\text { Collateral value } \\
\text { (US\$) }\end{array}$ \\
\hline 1 & 30,000 & 18 & friends/relatives & no & na & na \\
\hline 2 & 30,000 & 24 & friends/relatives & no & na & na \\
\hline 3 & 30,000 & 24 & friends/relatives & yes & apartment & unspecified \\
\hline 4 & 30,000 & 36 & friends/relatives & no & na & na \\
\hline 5 & 30,000 & 36 & friends/relatives & yes & apartment & unspecified \\
\hline 6 & 30,000 & 48 & friends/relatives & no. & na & na \\
\hline 7 & 100,000 & 13 & bank & yes & estate & 100,000 \\
\hline 8 & 100,000 & 13 & bank & yes & estate & 200,000 \\
\hline 9 & 100,000 & 13 & bank & yes & apartment & 200,000 \\
\hline 10 & 100,000 & 13 & bank & yes & estate & 300,000 \\
\hline 11 & 100,000 & 13 & SME bank & no. & na & na \\
\hline 12 & & & not qualifiec & hy loans & & \\
\hline
\end{tabular}


Table 5: Variations in PS Vignettes

\begin{tabular}{|c|c|c|c|c|c|c|c|c|}
\hline Vignette & $\begin{array}{c}\text { Cost } \\
(1000 \mathrm{US} \$)\end{array}$ & $\begin{array}{c}\text { Number of } \\
\text { days }\end{array}$ & $\begin{array}{c}\text { Number of } \\
\text { official } \\
\text { procedures }\end{array}$ & $\begin{array}{l}\text { Can complete } \\
\text { paperwork in } \\
\text { Yangon }\end{array}$ & $\begin{array}{c}\text { Paperwork } \\
\text { involves trip to } \\
\text { the capital }\end{array}$ & $\begin{array}{c}\text { Can complete } \\
\text { paperwork } \\
\text { online }\end{array}$ & $\begin{array}{l}\text { Days to clear } \\
\text { invoice }\end{array}$ & $\begin{array}{l}\text { Number of } \\
\text { official } \\
\text { signatures } \\
\text { required }\end{array}$ \\
\hline 1 & 1.20 & 60 & 11 & No & No & No & 0 & 0 \\
\hline 2 & 1.20 & 3 & 2 & No & No & No & 0 & 0 \\
\hline 3 & 0 & 0 & 0 & Yes & No & No & 0 & 0 \\
\hline 4 & 0 & 0 & 0 & No & Yes & No & 0 & 0 \\
\hline 5 & 0 & 0 & 0 & No & No & Yes & 0 & 0 \\
\hline 6 & 0 & 14 & 0 & No & No & No & 14 & 3 \\
\hline 7 & 0 & 14 & 0 & No & No & No & 14 & 1 \\
\hline 8 & 0 & 2 & 0 & No & No & No & 2 & 1 \\
\hline 9 & 4.50 & 150 & 0 & No & No & No & 0 & 0 \\
\hline
\end{tabular}


Table 6: Variations in Electricity Vignettes

\begin{tabular}{|c|c|c|c|c|c|c|c|c|}
\hline Vignette & $\begin{array}{c}\text { New } \\
\text { connection }\end{array}$ & $\begin{array}{c}\text { Business located } \\
\text { in an industrial } \\
\text { zone }\end{array}$ & $\begin{array}{c}\text { Hours operating } \\
\text { generator each } \\
\text { day }\end{array}$ & $\begin{array}{c}\text { Complete lack } \\
\text { of electricity }\end{array}$ & $\begin{array}{l}\text { Generator to } \\
\text { power air } \\
\text { conditioning } \\
\text { only }\end{array}$ & $\begin{array}{l}\text { Application } \\
\text { pending }\end{array}$ & $\begin{array}{l}\text { Without } \\
\text { electricity one } \\
\text { hour each day }\end{array}$ & $\begin{array}{c}\text { Rare power } \\
\text { outage and } \\
\text { voltage is } \\
\text { sufficient }\end{array}$ \\
\hline 1 & Yes & No & 0 & No & No & No & No & No \\
\hline 2 & No & Yes & 6 & No & No & No & No & No \\
\hline 3 & No & No & 4 & No & No & No & No & No \\
\hline 4 & No & No & 0 & Yes & No & No & No & No \\
\hline 5 & No & No & 0 & No & Yes & No & No & No \\
\hline 6 & No & No & 8 & No & No & No & No & No \\
\hline 7 & No & No & 0 & No & No & Yes & No & No \\
\hline 8 & No & No & 0 & No & No & No & Yes & No \\
\hline 9 & No & No & 0 & No & No & No & No & Yes \\
\hline
\end{tabular}


Table 7: Summary Statistics of Vignette Evaluations

\begin{tabular}{|c|c|c|c|c|c|c|c|}
\hline Domain & Vignette & $\mathrm{N}$ & Mean & $\mathrm{SD}$ & Min & Max & \% "major" or "severe" \\
\hline \multirow{12}{*}{ Credit } & 1 & 258 & 2.53 & 1.19 & 1 & 5 & 20 \\
\hline & 2 & 258 & 2.57 & 1.19 & 1 & 5 & 22 \\
\hline & 3 & 241 & 2.78 & 1.15 & 1 & 5 & 24 \\
\hline & 4 & 248 & 3.09 & 1.14 & 1 & 5 & 37 \\
\hline & 5 & 254 & 3.21 & 1.16 & 1 & 5 & 42 \\
\hline & 6 & 242 & 3.29 & 1.25 & 1 & 5 & 47 \\
\hline & 7 & 227 & 2.92 & 1.19 & 1 & 5 & 33 \\
\hline & 8 & 244 & 2.95 & 1.05 & 1 & 5 & 31 \\
\hline & 9 & 222 & 2.82 & 1.15 & 1 & 5 & 23 \\
\hline & 10 & 254 & 3.00 & 1.14 & 1 & 5 & 30 \\
\hline & 11 & 269 & 2.84 & 1.20 & 1 & 5 & 29 \\
\hline & 12 & 271 & 3.39 & 1.16 & 1 & 5 & 52. \\
\hline \multirow{9}{*}{$\begin{array}{l}\text { Public } \\
\text { Services }\end{array}$} & 1 & 315 & 3.94 & 0.93 & 1 & 5 & 70 \\
\hline & 2 & 365 & 2.99 & 1.11 & 1 & 5 & 32 \\
\hline & 3 & 365 & 1.45 & 0.76 & 1 & 5 & 2 \\
\hline & 4 & 363 & 3.37 & 0.89 & 1 & 5 & 43 \\
\hline & 5 & 273 & 1.44 & 0.74 & 1 & 4 & 2 \\
\hline & 6 & 342 & 3.42 & 0.96 & 1 & 5 & 48 \\
\hline & 7 & 297 & 3.35 & 0.99 & 1 & 5 & 42 \\
\hline & 8 & 325 & 2.68 & 1.02 & 1 & 5 & 20 \\
\hline & 9 & 314 & 3.99 & 0.87 & 1 & 5 & 72. \\
\hline \multirow{9}{*}{ Electricity } & 1 & 341 & 3.69 & 1.08 & 1 & 5 & 61 \\
\hline & 2 & 360 & 4.16 & 0.74 & 1 & 5 & 87 \\
\hline & 3 & 332 & 3.86 & 0.76 & 1 & 5 & 72 \\
\hline & 4 & 359 & 4.33 & 0.80 & 1 & 5 & 90 \\
\hline & 5 & 296 & 2.58 & 0.98 & 1 & 5 & 17 \\
\hline & 6 & 346 & 4.47 & 0.71 & 1 & 5 & 93 \\
\hline & 7 & 326 & 3.47 & 1.03 & 1 & 5 & 51 \\
\hline & 8 & 320 & 2.83 & 1.20 & 1 & 5 & 30 \\
\hline & 9 & 311 & 2.58 & 1.37 & 1 & 5 & 30 \\
\hline
\end{tabular}


Figure 2: Distributions of Vignette Evaluations: Credit

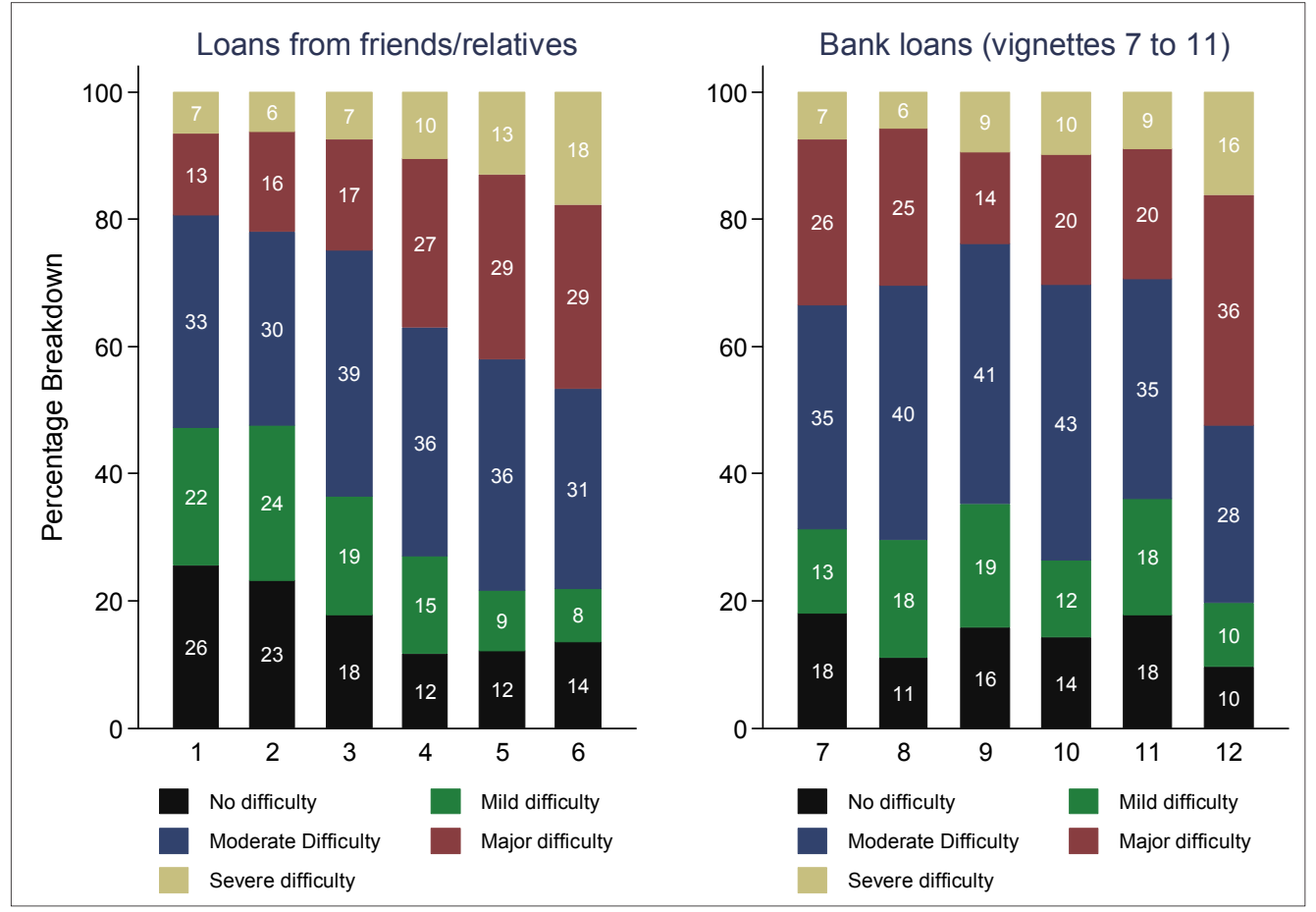

Figure 3: Distribution of Vignette Evaluations: Public Services

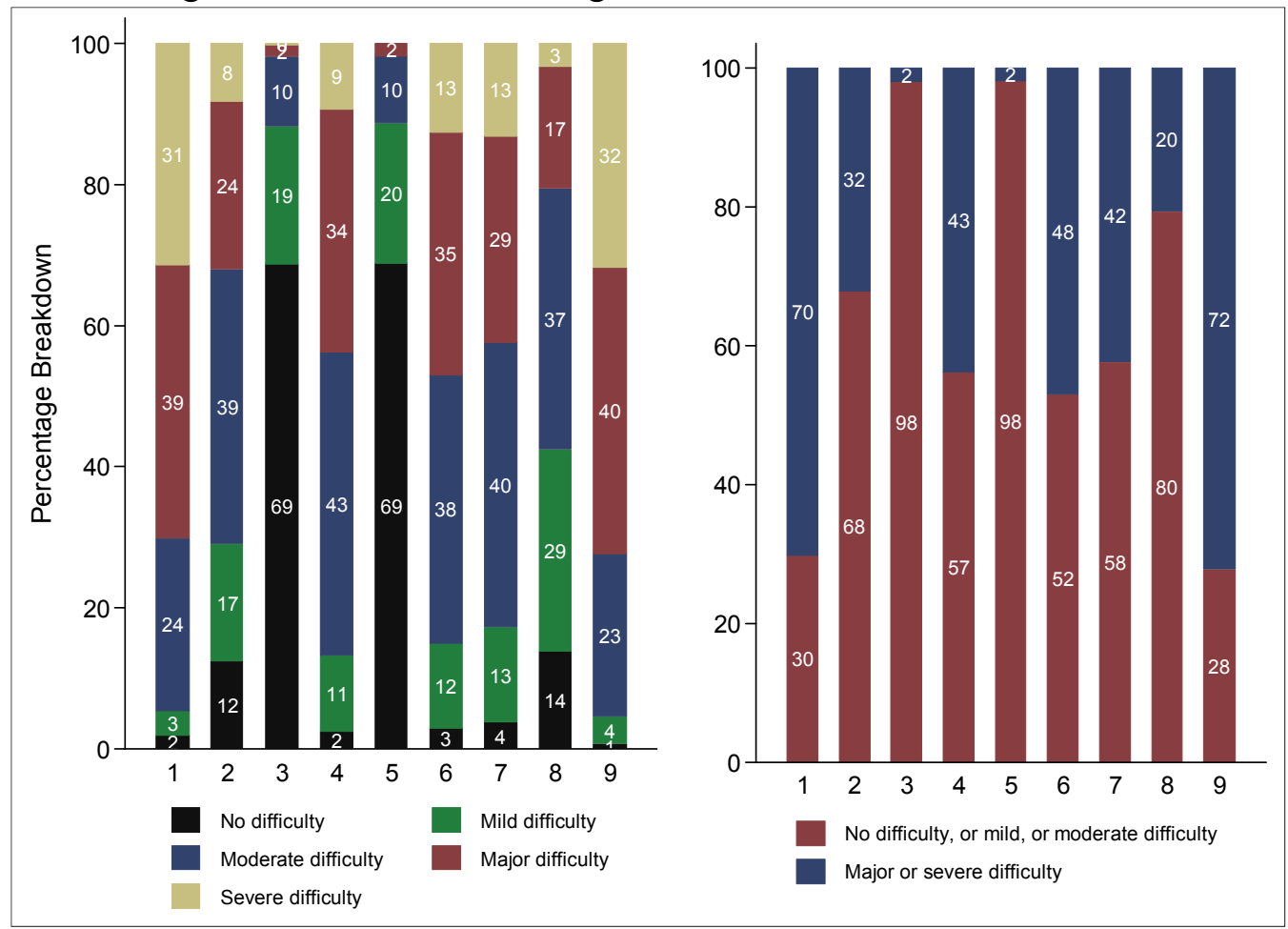


Figure 4: Distribution of Vignette Evaluations: Electricity

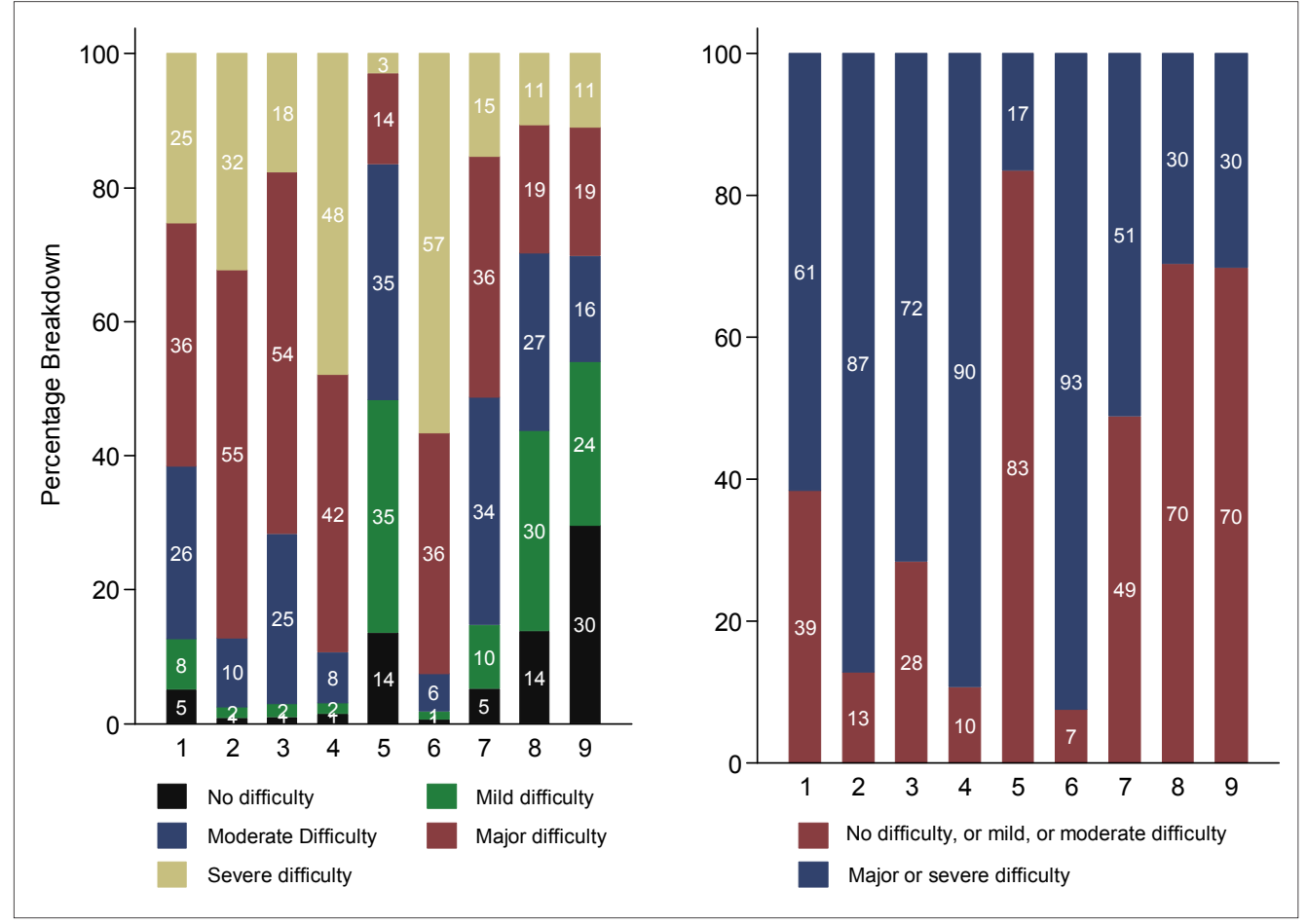

Table 8: Sample Statistics of Characrtersitics in Credit Vignettes

\begin{tabular}{lll}
\hline \hline & Frequency & $\%$ \\
\hline Annual interest rate (\%) & 1216 & 41 \\
13 & 258 & 9 \\
18 & 499 & 17 \\
24 & 502 & 17 \\
36 & 242 & 8 \\
48 & & \\
Source of loan & 1501 & 50 \\
Friends/relatives & 1216 & 41 \\
Bank & 269 & 9 \\
SME bank & & 32 \\
Collateral & 947 & 24 \\
Real estate & 717 & 44 \\
Apartment & 1324 & 68 \\
Collateral free & & 8 \\
Collateral value & 2041 & 16 \\
$0 \%$ loan amount & 227 & 9 \\
100\% loan amount & 466 & 9 \\
200\% loan amount & 254 & \\
300\% loan amount & 271 & \\
No access to credit at all & 2988 & \\
Observations & & \\
\hline \hline
\end{tabular}


Table 9: Sample Statistics of Characrtersitics in PS Vignettes

\begin{tabular}{lll}
\hline \hline & Frequency & $\%$ \\
\hline Fees to obtain a service (US\$) & 680 & 23 \\
1200 & 314 & 11 \\
4500 & 315 & 11 \\
Duration to receive a public service (days) & 365 & 12 \\
60 & 314 & 11 \\
3 & & \\
150 & 315 & 11 \\
Number of official procedures & 365 & 12 \\
11 & 365 & 12 \\
2 & 363 & 12 \\
Any paperwork can be completed in Yangon & 273 & 9 \\
A trip to capital is required to complete any paperwork & & 12 \\
Any paperwork can be completed online & 342 & 10 \\
Number of days it takes to clear an invoice & 297 & 11 \\
14 & 325 & 12 \\
14 & & 10 \\
2 & 342 & 11 \\
Number of official signatures required to clear an invoice & 297 & \\
3 & 325 & \\
1 & 2959 & \\
1 & & \\
\hline Observations & & \\
\hline \hline
\end{tabular}


Table 10: Sample Statistics of Characrtersitics in Electricity Vignettes

\begin{tabular}{lcc}
\hline \hline & Frequency & $\%$ \\
\hline Businesses trying to receive new electricity connection & 341 & 11 \\
Businesses located in an industrial zone & 360 & 12 \\
Total hours operating generator each day due to outage & 360 & 12 \\
6 & 332 & 11 \\
4 & 346 & 12 \\
8 & 359 & 12 \\
Businesses operating without any electricity & 296 & 10 \\
Businesses using generator to mainly power air conditioning & 326 & 11 \\
Businesses whose application for new connections are pending & 320 & 11 \\
Businesses operating without electricity for an hour each day & 311 & 10 \\
Businesses rarely experiencing power outage and insufficient voltage & 2991 & \\
\hline Observations & &
\end{tabular}

Table 11: Effects of Credit Vignette Descriptions on Evaluations

\begin{tabular}{llll}
\hline \hline & OLS & Ordered logit & Logit \\
\hline Interest & 0.029 & 0.047 & 0.048 \\
& {$[0.003]^{* * *}$} & {$[0.005]^{* * *}$} & {$[0.006]^{* * *}$} \\
Bank loan & 0.537 & 0.908 & 1.084 \\
& {$[0.132]^{* * *}$} & {$[0.206]^{* * *}$} & {$[0.255]^{* * *}$} \\
SME bank loan & -0.032 & -0.096 & -0.238 \\
Value of collateralized real estate & {$[0.133]$} & {$[0.206]$} & {$[0.246]$} \\
& 0.040 & 0.043 & -0.072 \\
Apartment & {$[0.050]$} & {$[0.077]$} & {$[0.096]$} \\
& 0.170 & 0.265 & 0.215 \\
Bank loan x apartment & {$[0.063]^{* * *}$} & {$[0.098]^{* * *}$} & {$[0.120]^{*}$} \\
& -0.301 & -0.502 & -0.591 \\
Vignette 12 & {$[0.103]^{* * *}$} & {$[0.156]^{* * *}$} & {$[0.204]^{* * *}$} \\
& 1.429 & 2.330 & 2.441 \\
Constant & {$[0.124]^{* * *}$} & {$[0.202]^{* * *}$} & {$[0.235]^{* * *}$} \\
& 1.966 & & -2.345 \\
$\mathrm{~N}$ & {$[0.106]^{* * *}$} & & {$[0.209]^{* * *}$} \\
R-squared & 2988 & 2988 & 2988 \\
Controls & 0.046 & $\mathrm{NA}$ & $\mathrm{NA}$ \\
\hline Robust standard errors (clustered at respondent level) are in brackets. *significant at $10 \%$ level, & $\mathrm{N}$ \\
*** at $5 \%$ level, and \\
\end{tabular}


Table 12: Effects of PS Vignette Descriptions on Evaluations

\begin{tabular}{|c|c|c|c|}
\hline & OLS & Ordered logit & Logit \\
\hline \multirow[t]{2}{*}{ Fees (1000 US\$) } & 0.229 & 0.434 & 0.452 \\
\hline & {$[0.064] * * *$} & {$[0.119] * * *$} & {$[0.143]^{* * *}$} \\
\hline \multirow[t]{2}{*}{ Days to receive a service } & 0.003 & 0.005 & 0.004 \\
\hline & {$[0.002]^{*}$} & {$[0.003]^{*}$} & {$[0.004]$} \\
\hline \multirow{2}{*}{ Number of official procedures involved } & 0.088 & 0.167 & 0.156 \\
\hline & {$[0.008] * * *$} & {$[0.016]^{* * *}$} & {$[0.019]^{* * *}$} \\
\hline \multirow[t]{2}{*}{ Vignette 3} & -1.078 & -2.252 & -2.318 \\
\hline & {$[0.080]^{* * *}$} & {$[0.174]^{* * *}$} & {$[0.410]^{* * *}$} \\
\hline \multirow{2}{*}{ Vignette 4} & 0.845 & 1.527 & 1.367 \\
\hline & {$[0.081]^{* * *}$} & {$[0.153]^{* * *}$} & {$[0.196]^{* * *}$} \\
\hline \multirow[t]{2}{*}{ Vignette 5} & -1.086 & -2.263 & -2.365 \\
\hline & {$[0.082] * * *$} & {$[0.184]^{* * *}$} & {$[0.484]^{* * *}$} \\
\hline \multirow[t]{2}{*}{ Days to clear invoice } & 0.053 & 0.095 & 0.083 \\
\hline & {$[0.007] * * *$} & {$[0.013]^{* * *}$} & {$[0.016]^{* * *}$} \\
\hline \multirow[t]{2}{*}{ Number of official signatures required } & 0.036 & 0.072 & 0.094 \\
\hline & {$[0.036]$} & {$[0.068]$} & {$[0.075]$} \\
\hline \multirow[t]{2}{*}{ Constant } & 2.530 & & -1.616 \\
\hline & {$[0.072] * * *$} & & {$[0.171]^{* * *}$} \\
\hline $\mathrm{N}$ & 2959 & 2959 & 2959 \\
\hline R-squared & 0.475 & NA & NA \\
\hline Controls & No & No & No \\
\hline
\end{tabular}

Table 13: Effects of Electricity Vignette Descriptions on Evaluations

\begin{tabular}{llll}
\hline \hline & OLS & Ordered logit & Logit \\
\hline New connection (vignette 1) & 0.449 & 1.318 & 1.124 \\
& {$[0.104]^{* * *}$} & {$[0.211]^{* * *}$} & $0.319]^{* * *}$ \\
If business located in industrial zone (vignette 2) & -0.001 & -0.084 & 0.201 \\
& {$[0.196]$} & 0.395 \\
Hours of outage each day & 0.153 & 0.371 & {$[0.057]^{* * *}$} \\
Complete lack of electricity (vignette 4) & {$[0.013]^{* * *}$} & {$[0.031]^{* * *}$} & 2.786 \\
& 1.086 & 2.629 & {$[0.350]^{* * *}$} \\
Generator mainly to power air conditioning (vignette 5) & {$[0.094]^{* * *}$} & {$[0.206]^{* * *}$} & -0.965 \\
& -0.665 & -0.603 & {$[0.340]^{* * *}$} \\
Application for connection pending (vignette 7) & {$[0.104]^{* * *}$} & {$[0.198]^{* * *}$} & 0.701 \\
Without electricity one hour each day (vignette 8$)$ & 0.224 & 0.846 & {$[0.325]^{* *}$} \\
Rare outage and sufficient voltage (vignette 9) & {$[0.102]^{* *}$} & {$[0.201]^{* * *}$} & -0.210 \\
Constant & -0.415 & -0.248 & {$[0.327]$} \\
& {$[0.109]^{* * *}$} & {$[0.211]$} & -0.184 \\
N & -0.667 & -0.705 & {$[0.320]$} \\
Controls & {$[0.114]^{* * *}$} & {$[0.231]^{* * *}$} & -0.652 \\
\hline \hline
\end{tabular}

Robust standard errors (clustered at respondent level) are in brackets. *significant at 10\% level, ** at 5\% level, and $* * *$ at $1 \%$ level. 
Table 14: Estimates of Ordered Logit and CHOPIT Models (Dependent Variable: Subjective Measures of Credit Difficulty on a 5point Scale)

\begin{tabular}{|c|c|c|c|c|c|c|}
\hline & Ordered Probit & CHOPIT & & & & \\
\hline & $\beta$ & $\beta$ & $\tau_{1}$ & $\operatorname{Ln}\left(\tau_{2}-\tau_{1}\right)$ & $\operatorname{Ln}\left(\tau_{3}-\tau_{2}\right)$ & $\operatorname{Ln}\left(\tau_{4}-\tau_{3}\right)$ \\
\hline Age (40-50) & $\begin{array}{l}0.152 \\
{[0.084]^{*}}\end{array}$ & $\begin{array}{l}0.158 \\
{[0.091]^{*}}\end{array}$ & $\begin{array}{l}-0.013 \\
{[0.063]}\end{array}$ & $\begin{array}{l}0.022 \\
{[0.088]}\end{array}$ & $\begin{array}{l}0.042 \\
{[0.059]}\end{array}$ & $\begin{array}{l}-0.101 \\
{[0.076]}\end{array}$ \\
\hline Age(51-64) & $\begin{array}{l}-0.170 \\
{[0.095]^{*}}\end{array}$ & $\begin{array}{l}-0.167 \\
{[0.109]}\end{array}$ & $\begin{array}{l}0.016 \\
{[0.069]}\end{array}$ & $\begin{array}{l}-0.028 \\
{[0.098]}\end{array}$ & $\begin{array}{l}0.062 \\
{[0.066]}\end{array}$ & $\begin{array}{l}-0.063 \\
{[0.090]}\end{array}$ \\
\hline $\operatorname{Age}(65+)$ & $\begin{array}{l}-0.558 \\
{[0.188] * * *}\end{array}$ & $\begin{array}{l}-0.344 \\
{[0.221]}\end{array}$ & $\begin{array}{l}0.197 \\
{[0.144]}\end{array}$ & $\begin{array}{l}0.105 \\
{[0.170]}\end{array}$ & $\begin{array}{l}0.014 \\
{[0.146]}\end{array}$ & $\begin{array}{l}0.033 \\
{[0.193]}\end{array}$ \\
\hline Medium education & $\begin{array}{l}0.011 \\
{[0.079]}\end{array}$ & $\begin{array}{l}0.105 \\
{[0.090]}\end{array}$ & $\begin{array}{l}0.114 \\
{[0.058]^{*}}\end{array}$ & $\begin{array}{l}-0.032 \\
{[0.083]}\end{array}$ & $\begin{array}{l}0.013 \\
{[0.056]}\end{array}$ & $\begin{array}{l}-0.036 \\
{[0.072]}\end{array}$ \\
\hline High education & $\begin{array}{l}0.016 \\
{[0.133]}\end{array}$ & $\begin{array}{l}-0.060 \\
{[0.155]}\end{array}$ & $\begin{array}{l}-0.096 \\
{[0.105]}\end{array}$ & $\begin{array}{l}-0.060 \\
{[0.146]}\end{array}$ & $\begin{array}{l}0.145 \\
{[0.092]}\end{array}$ & $\begin{array}{l}0.161 \\
{[0.114]}\end{array}$ \\
\hline Ethnic Myanmar & $\begin{array}{l}-0.057 \\
{[0.072]}\end{array}$ & $\begin{array}{l}-0.043 \\
{[0.081]}\end{array}$ & $\begin{array}{l}0.082 \\
{[0.055]}\end{array}$ & $\begin{array}{l}-0.164 \\
{[0.076]^{* *}}\end{array}$ & $\begin{array}{l}-0.039 \\
{[0.050]}\end{array}$ & $\begin{array}{l}-0.007 \\
{[0.067]}\end{array}$ \\
\hline Male & $\begin{array}{l}0.083 \\
{[0.081]}\end{array}$ & $\begin{array}{l}-0.022 \\
{[0.092]}\end{array}$ & $\begin{array}{l}-0.088 \\
{[0.057]}\end{array}$ & $\begin{array}{l}0.011 \\
{[0.083]}\end{array}$ & $\begin{array}{l}-0.073 \\
{[0.055]}\end{array}$ & $\begin{array}{l}-0.014 \\
{[0.085]}\end{array}$ \\
\hline Small-sized business & {$[0.084]^{* *}$} & {$[0.093]^{* *}$} & $\begin{array}{l}-0.050 \\
{[0.062]}\end{array}$ & $\begin{array}{l}0.110 \\
{[0.089]}\end{array}$ & $\begin{array}{l}0.110 \\
{[0.059]^{*}}\end{array}$ & $\begin{array}{l}-0.024 \\
{[0.076]}\end{array}$ \\
\hline Selling goods or services to government & $\begin{array}{l}0.110 \\
{[0.091]}\end{array}$ & $\begin{array}{l}0.182 \\
{[0.098]^{*}}\end{array}$ & $\begin{array}{l}0.028 \\
{[0.067]}\end{array}$ & $\begin{array}{l}0.011 \\
{[0.099]}\end{array}$ & $\begin{array}{l}0.080 \\
{[0.063]}\end{array}$ & $\begin{array}{l}0.009 \\
{[0.085]}\end{array}$ \\
\hline If respondent is owner & $\begin{array}{l}0.263 \\
{[0.106]^{* *}}\end{array}$ & $\begin{array}{l}0.168 \\
{[0.129]}\end{array}$ & $\begin{array}{l}-0.035 \\
{[0.080]}\end{array}$ & $\begin{array}{l}-0.150 \\
{[0.101]}\end{array}$ & $\begin{array}{l}-0.132 \\
{[0.076]^{*}}\end{array}$ & $\begin{array}{l}0.131 \\
{[0.115]}\end{array}$ \\
\hline $\begin{array}{l}\text { Located in an industrial zone } \\
\text { Constant }\end{array}$ & $\begin{array}{l}0.158 \\
{[0.088]^{*}}\end{array}$ & $\begin{array}{l}0.025 \\
{[0.101]} \\
-1.137 \\
{[0.191]^{* * *}}\end{array}$ & $\begin{array}{l}-0.109 \\
{[0.067]} \\
-1.076 \\
{[0.137]^{* * *}}\end{array}$ & $\begin{array}{l}-0.038 \\
{[0.100]} \\
-0.599 \\
{[0.152]^{* * *}}\end{array}$ & $\begin{array}{l}-0.099 \\
{[0.063]} \\
-0.019 \\
{[0.116]}\end{array}$ & $\begin{array}{l}-0.011 \\
{[0.077]} \\
-0.243 \\
{[0.163]}\end{array}$ \\
\hline $\begin{array}{l}\text { Likelihood Ratio Test } \\
\text { (CHOPIT Vs Ordered Probit, with ordered probit } \\
\text { model being nested in the CHOPIT model) }\end{array}$ & \multicolumn{6}{|c|}{$\mathrm{P}-$ Value $=1.000$} \\
\hline $\mathrm{N}$ & \multicolumn{6}{|c|}{980} \\
\hline
\end{tabular}

Standard errors are in brackets. * significant at 10\% level, $* *$ significant at 5\% level, and *** significant at $1 \%$ level. 
Table 15: Estimates of Ordered Logit and CHOPIT Models (Dependent Variable: Subjective Measures of Electricity Difficulty on a 5point Scale)

\begin{tabular}{|c|c|c|c|c|c|c|}
\hline & \multirow{2}{*}{$\begin{array}{c}\text { Ordered Probit } \\
\beta\end{array}$} & \multicolumn{5}{|l|}{ CHOPIT } \\
\hline & & $\beta$ & $\tau_{1}$ & $\operatorname{Ln}\left(\tau_{2}-\tau_{1}\right)$ & $\operatorname{Ln}\left(\tau_{3}-\tau_{2}\right)$ & $\operatorname{Ln}\left(\tau_{4}-\tau_{3}\right)$ \\
\hline \multirow[t]{2}{*}{ Age (40-50) } & 0.040 & 0.067 & 0.035 & -0.050 & 0.024 & -0.017 \\
\hline & {$[0.081]$} & {$[0.097]$} & {$[0.075]$} & {$[0.093]$} & {$[0.075]$} & {$[0.055]$} \\
\hline \multirow[t]{2}{*}{$\operatorname{Age}(51-64)$} & -0.095 & -0.082 & 0.026 & -0.027 & -0.030 & 0.071 \\
\hline & {$[0.091]$} & {$[0.108]$} & {$[0.078]$} & {$[0.100]$} & {$[0.085]$} & {$[0.061]$} \\
\hline \multirow[t]{2}{*}{$\operatorname{Age}(65+)$} & -0.168 & -0.059 & 0.259 & -0.189 & -0.151 & -0.136 \\
\hline & {$[0.173]$} & {$[0.206]$} & {$[0.147]^{*}$} & {$[0.195]$} & {$[0.157]$} & {$[0.119]$} \\
\hline \multirow[t]{2}{*}{ Medium education } & 0.031 & 0.069 & -0.031 & 0.131 & 0.016 & 0.053 \\
\hline & {$[0.076]$} & {$[0.092]$} & {$[0.068]$} & {$[0.084]$} & {$[0.070]$} & {$[0.051]$} \\
\hline \multirow[t]{2}{*}{ High education } & 0.164 & 0.138 & -0.125 & 0.148 & 0.071 & 0.066 \\
\hline & {$[0.127]$} & {$[0.151]$} & {$[0.111]$} & {$[0.155]$} & {$[0.117]$} & {$[0.085]$} \\
\hline \multirow[t]{2}{*}{ Ethnic Myanmar } & 0.054 & -0.007 & 0.002 & -0.147 & -0.031 & 0.051 \\
\hline & {$[0.070]$} & {$[0.082]$} & {$[0.064]$} & {$[0.077]^{*}$} & {$[0.063]$} & {$[0.047]$} \\
\hline \multirow[t]{2}{*}{ Male } & 0.037 & 0.122 & 0.136 & -0.046 & -0.054 & -0.081 \\
\hline & {$[0.078]$} & {$[0.094]$} & {$[0.072]^{*}$} & {$[0.088]$} & {$[0.073]$} & {$[0.052]$} \\
\hline \multirow[t]{2}{*}{ Small-sized business } & -0.272 & -0.195 & 0.060 & 0.109 & -0.020 & -0.005 \\
\hline & {$[0.079]^{* * *}$} & {$[0.094]^{* *}$} & {$[0.075]$} & {$[0.096]$} & {$[0.078]$} & {$[0.053]$} \\
\hline \multirow[t]{2}{*}{ Selling goods or services to government } & -0.108 & -0.182 & -0.084 & 0.047 & -0.014 & 0.019 \\
\hline & {$[0.088]$} & {$[0.106]^{*}$} & {$[0.081]$} & {$[0.100]$} & {$[0.079]$} & {$[0.060]$} \\
\hline \multirow[t]{2}{*}{ If respondent is owner } & 0.037 & 0.108 & 0.127 & -0.074 & -0.044 & -0.024 \\
\hline & {$[0.101]$} & {$[0.116]$} & {$[0.101]$} & {$[0.119]$} & {$[0.095]$} & {$[0.068]$} \\
\hline \multirow[t]{2}{*}{ Located in an industrial zone } & 0.468 & 0.555 & 0.068 & -0.041 & 0.012 & 0.046 \\
\hline & {$[0.085]^{* * *}$} & {$[0.099]^{* * *}$} & {$[0.079]$} & {$[0.106]$} & {$[0.080]$} & {$[0.056]$} \\
\hline \multirow[t]{2}{*}{ Constant } & & -1.202 & -1.994 & -0.491 & -0.241 & 0.025 \\
\hline & & {$[0.191]^{* * *}$} & {$[0.175]^{* * *}$} & {$[0.166] * * *$} & {$[0.139]^{*}$} & {$[0.105]$} \\
\hline
\end{tabular}

\section{Likelihood Ratio Test}

(CHOPIT Vs Ordered Probit, with ordered probit

P-Value $=1.000$ model being nested in the CHOPIT model

1000

Standard errors are in brackets. *significant at $10 \%$ level, $* *$ significant at $5 \%$ level, and $* * *$ significant at $1 \%$ level. 
Table 16: Estimates of Ordered Logit and CHOPIT Models (Dependent Variable: Subjective Measures of Public Service Difficulty on a 5-point Scale)

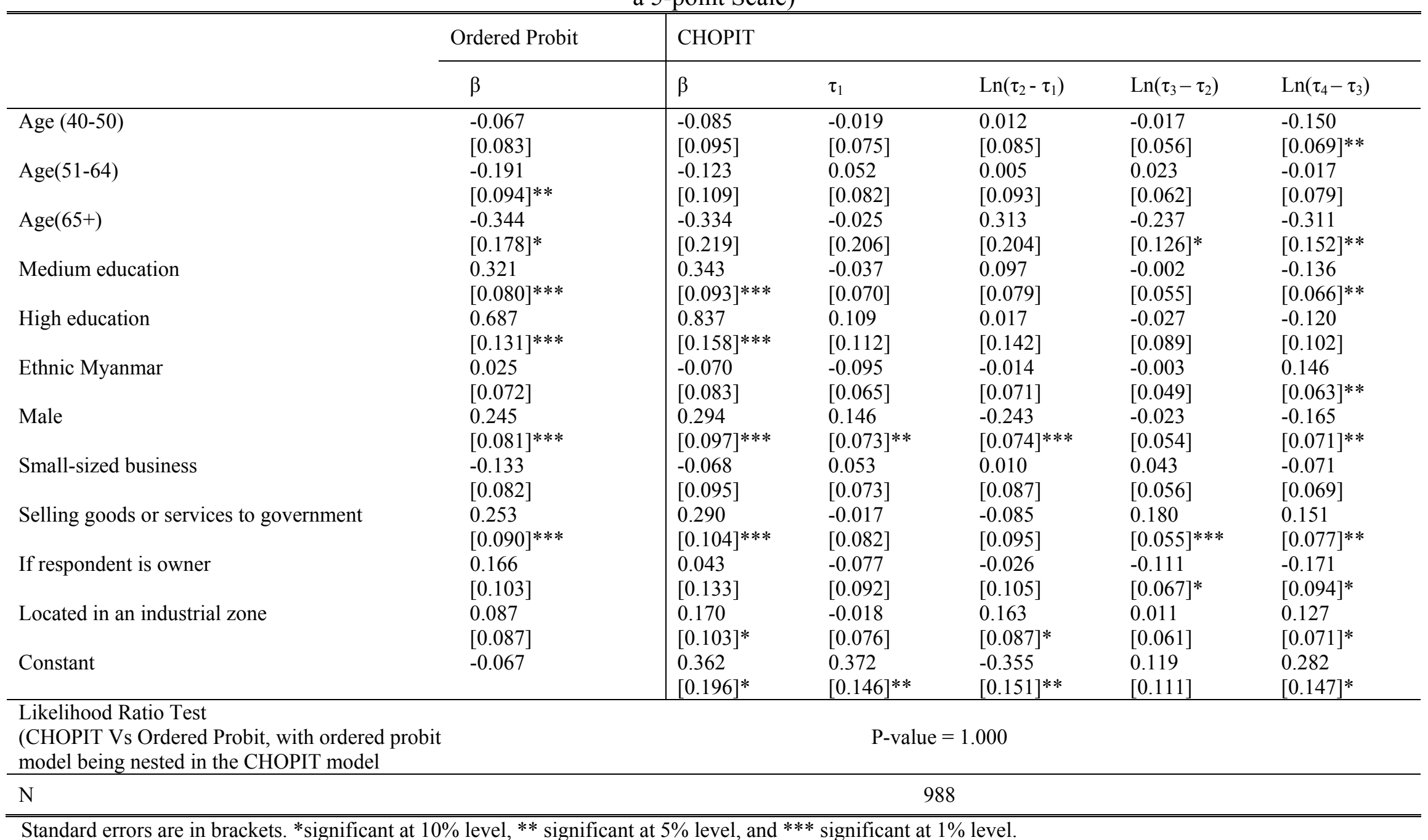

Standard errors are in brackets. *significant at 10\% level, ** significant at 5\% level, and *** significant at $1 \%$ level. 
Figure 5: Comparing Self-Reports Of Business Climate in Two Sub-Groups in The Case of DIF: (A) Group a; (B) Group b

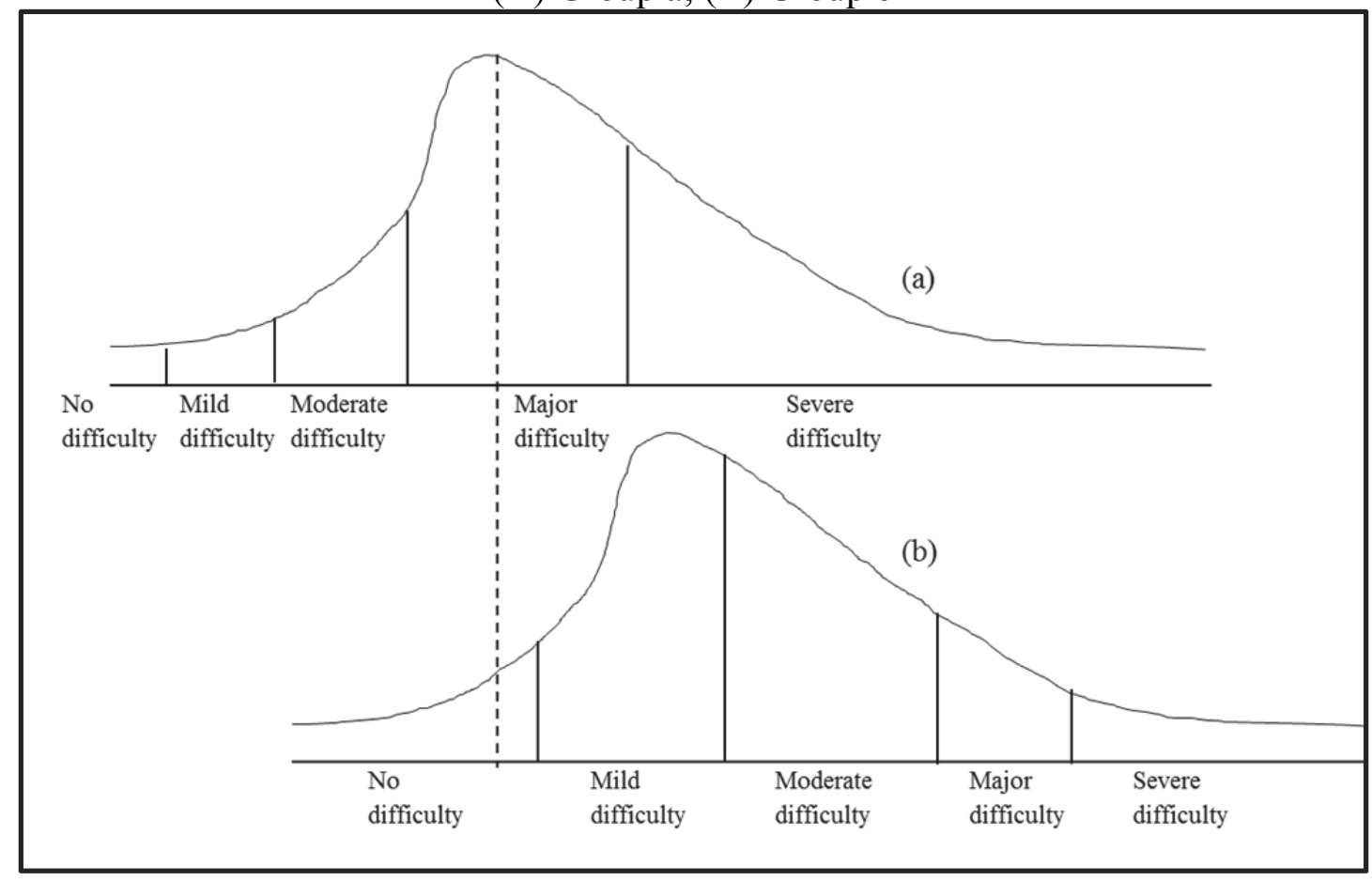




\section{REFERENCES}

Abe, Masato and Madhurjya Kumar Dutta. 2014. "A New Policy Framework for Myanmar's Sme Development," ARTNeT Working Paper Series.

Bago d'Uva, Teresa; Eddy Van Doorslaer; Maarten Lindeboom and Owen O'Donnell. 2008. "Does Reporting Heterogeneity Bias the Measurement of Health Disparities?" Health economics, 17(3), 351-75.

Banks, James; Michael Marmot; Zoe Oldfield and James P Smith. 2009. "The Ses Health Gradient on Both Sides of the Atlantic," Developments in the Economics of Aging. University of Chicago Press, 359-406.

Dowd, Jennifer Beam and Megan Todd. 2011. "Does Self-Reported Health Bias the Measurement of Health Inequalities in Us Adults? Evidence Using Anchoring Vignettes from the Health and Retirement Study." The Journals of Gerontology Series B: Psychological Sciences and Social Sciences, 66(4), 478-89.

Grol-Prokopczyk, Hanna; Jeremy Freese and Robert M Hauser. 2011. "Using Anchoring Vignettes to Assess Group Differences in General Self-Rated Health." Journal of health and social behavior, 52(2), 246-61.

IEA. 2012. "World Energy Outlook," International Energy Agency.

Kapteyn, Arie; James P Smith and Arthur Van Soest. 2013. "Are Americans Really Less Happy with Their Incomes?" Review of Income and Wealth, 59(1), 44-65. . 2009. "Life Satisfaction."

. 2007. "Vignettes and Self-Reports of Work Disability in the United States and the Netherlands."

The American Economic Review, 461-73.

King, Gary; Christopher JL Murray; Joshua A Salomon and Ajay Tandon. 2004. "Enhancing the Validity and Cross-Cultural Comparability of Measurement in Survey Research." American political science review, 98(01), 191-207.

Kristensen, Nicolai and Edvard Johansson. 2008. "New Evidence on Cross-Country Differences in Job Satisfaction Using Anchoring Vignettes." Labour Economics, 15(1), 96-117.

Kyaw, Aung. 2008. "Financing Small and Medium Enterprises in Myanmar." IDE Discussion Paper No. 148.

OECD. 2013. "Multi-Dimensional Review of Myanmar: Volume 1. Initial Assessment." OECD Development Pathways, OECD Publishing.

Subramanian, SV; Malavika A Subramanyam; Sakthivel Selvaraj and Ichiro Kawachi. 2009. "Are Self-Reports of Health and Morbidities in Developing Countries Misleading? Evidence from India." Social science \& medicine, 68(2), 260-65.

Van Soest, Arthur; Liam Delaney; Colm Harmon; Arie Kapteyn and James P Smith. 2011. "Validating the Use of Anchoring Vignettes for the Correction of Response Scale Differences in Subjective Questions." Journal of the Royal Statistical Society: Series A (Statistics in Society), 174(3), 575-95.

Vonkova, Hanka; Gema Zamarro; Vera Deberg and Collin Hitt. 2015. "Comparisons of Student Perceptions of Teacher's Performance in the Classroom: Using Parametric Anchoring Vignette Methods for Improving Comparability." 
Appendix A: Text of Vignettes

\section{Credit vignettes}

Vignette 1: U Ko Ko owns a service business. To expand his business, he has received a loan worth US\$ 30,000 from a relative at $18 \%$ APR (1.5\% per month) without collateral. Repayment timeframe is flexible. He is not qualified for any bank loans.

Vignette 2: U Soe Aung owns a logging business. To expand his business, he has received a loan worth US $\$ 30,000$ from a friend at $24 \%$ APR ( $2 \%$ per month) without collateral. Repayment timeframe is flexible. He is not qualified for any bank loans.

Vignette 3: U Win Naing owns a trading business. To expand his business, he has received a loan worth US $\$ 30,000$ from a friend at $24 \%$ APR ( $2 \%$ per month) with his apartment as collateral. Repayment timeframe is flexible. He is not qualified for any bank loans.

Vignette 4: U Lwin Aung owns a factory. To expand his business, he has received a loan worth US $\$ 30,000$ from a friend at $36 \%$ APR (3\% per month) without collateral. Repayment timeframe is flexible. He is not qualified for any bank loans.

Vignette 5: U Chit Tun owns a service business. To expand his business, he has received a loan worth US\$ 30,000 from a friend at 36\% APR (3\% per month) with his apartment as collateral. Repayment timeframe is flexible. He is not qualified for any bank loans.

Vignette 6: U Moe Gyi owns a factory. To expand his business, he has received a loan worth US \$ 30,000 from a friend at $48 \%$ APR ( $4 \%$ per month) without collateral. Repayment timeframe is flexible. He is not qualified for any bank loans.

Vignette 7: U Myo Win owns a construction company and wants to build a new apartment building. He has received a bank loan worth US\$100,000 at 13\% APR to finance the construction with his real estate worth US\$ 100,000 as collateral. The loan needs to be repaid one year after it is issued. He can't borrow that amount from friends or relatives.

Vignette 8: Ko Zaw Zaw owns a service business. To expand his business, he has received a bank loan worth US\$100,000 at 13\% APR with his real estate worth US\$200,000 as collateral. The loan needs to be fully repaid within 1 year after it is issued. He can't borrow that amount from friends or relatives.

Vignette 9: U Aung Aung owns a wholesale business. To expand his business, he has received a bank loan worth US\$100,000 at 13\% APR with his apartment worth US\$200,000 as collateral. The loan needs to be fully repaid one year after it is issued. He can't borrow that amount from friends or relatives.

Vignette 10: Ko Oo owns a crane rental business. To finance acquisition of a new crane, he has received a bank loan worth US\$ 100,000 at $13 \%$ APR with his real estate worth US $\$ 300,000$ as 
collateral. The loan needs to be fully repaid within 1 year after it is issued. He can't borrow that amount from friends or relatives.

Vignette 11: Ko Naing Kyaw Win operates a travel business. To finance acquisition of 3 new tour buses, she has received a loan worth US\$100,000 at 13\% APR from the recently created SME Bank without collateral. The loan needs to be repaid one year after it is issued. He can't borrow from friends or relatives.

Vignette 12: Ko Zaw Thet owns a service business. To expand his business, he has to use retained profits and personal savings. He is not qualified for a bank loan, and can't borrow from friends or relatives either.

\section{$\underline{\text { Public services vignettes }}$}

Vignette 1: It cost Daw Nu US\$ 1,200 in registration fees, took her 2 months, and involved 11 official procedures to formally register her business.

Vignette 2: It cost Ma Kay Thi US\$ 1,200 in registration fees, took her 3 days, and involved 2 official procedures to formally register her business.

Vignette 3: Ko Tony can complete all the administrative and paper work for his business operations in Yangon, no longer needs to travel to Nay Pyi Taw as he did before, and can pay the applications fees at any private banks.

Vignette 4: Ko Gyi has to make trips to Nay Pyi Taw to complete administrative and paper work for his business operations, because of the unavailability of these public services in Yangon.

Vignette 5: Khaing Khaing can now complete all administrative and paper work online for her business operations, and no longer needs to travel to Nay Pyi Taw as she did before.

Vignette 6: U Win Oo submits invoices to a government agency every month that require 3 officials' signatures for approval. It takes 2 weeks to get the invoices approved.

Vignette 7: U Toe submits invoices every month to a government agency which requires one official's signature for approval. It takes 2 weeks to get the invoices approved.

Vignette 8: U Ko Ko submits invoices every month to a government agency which requires one official's signature for approval. It takes 2 days to get the invoices approved.

Vignette 9: It has taken Ko Sunny 5 months to get a permit for the construction of his new business warehouse building, costing him US\$ 4500 in application fees.

\section{Electricity vignettes}

Vignette 1: It took U Min Min 3 months to get a new connection to electricity for his new warehouse. He paid US\$25,000 in connection fees, and US\$12,000 for a transformer. 
Vignette 2: Ko Naing owns a factory located in an industrial zone. Due to power outages or insufficient electrical voltage, his factory has to operate a generator 6 hours a day to power the factory operations.

Vignette 3: U Kyi owns a printing business. Due to low electricity voltage, his business has to operate a generator 4 hours a day to power the printing machine.

Vignette 4: U Yin Aung owns a brick factory. Due to the lack of electricity supply, he has to use a power generator to fully power his factory operations.

Vignette 5: U Aung Aung owns an export/import business. Due to low electricity voltage, his office sometimes has to operate generator mainly to power air conditioners.

Vignette 6: Ko Htoo is the owner of a factory. Due to low electricity voltage, he has to operate a generator for 8 hours a day to power the machine tools for almost every day.

Vignette 7: Ko Zaw Thet is the owner of a newly established service business. Since his application for a connection to new electricity is still pending, his office has been sharing electricity with a neighboring office temporarily until the application is approved.

Vignette 8: Ko Win owns a trading business. His office experiences power outage lasting an hour on average every day. His office doesn't own a power generator and has to operate the business without electricity during outage.

Vignette 9: U Hlaing owns a garment factory. His factory seldom experiences power outage and the electrical voltage is sufficient for the factory to operate. 
Appendix B: List of Survey Items Used In Existing Enterprise Surveys

\begin{tabular}{|c|c|c|}
\hline Survey item & Survey & Response Scale \\
\hline To what degree is Telecommunications an obstacle to the current operations of this establishment? & $\begin{array}{l}\text { World Bank's } \\
\text { enterprise survey }\end{array}$ & $\begin{array}{l}5 \text { point (1="no } \\
\text { obstacle"; 5="severe" }\end{array}$ \\
\hline To what degree is Customs and Trade Regulation an obstacle to the current operations of this establishment? & $\begin{array}{l}\text { World Bank's } \\
\text { enterprise survey }\end{array}$ & $\begin{array}{l}5 \text { point (1="no } \\
\text { obstacle"; 5="severe" }\end{array}$ \\
\hline To what degree are Practices of Competitors in the Informal Sector an obstacle to the current operations of this establishment? & $\begin{array}{l}\text { World Bank's } \\
\text { enterprise survey }\end{array}$ & $\begin{array}{l}5 \text { point (1="no } \\
\text { obstacle"; 5="severe" }\end{array}$ \\
\hline To what degree is Access to Land an obstacle to the current operations of this establishment? & $\begin{array}{l}\text { World Bank's } \\
\text { enterprise survey }\end{array}$ & $\begin{array}{l}5 \text { point (1="no } \\
\text { obstacle"; 5="severe" }\end{array}$ \\
\hline To what degree is Crime, Theft and Disorder an obstacle to the current operations of this establishment? & $\begin{array}{l}\text { World Bank's } \\
\text { enterprise survey }\end{array}$ & $\begin{array}{l}5 \text { point }(1=" \text { no } \\
\text { obstacle"; 5="severe" }\end{array}$ \\
\hline To what degree is Access to Finance an obstacle to the current operations of this establishment? & $\begin{array}{l}\text { World Bank's } \\
\text { enterprise survey }\end{array}$ & $\begin{array}{l}5 \text { point (1="no } \\
\text { obstacle"; 5="severe" }\end{array}$ \\
\hline To what degree is/are Tax rates an obstacle to the current operations of this establishment? & $\begin{array}{l}\text { World Bank's } \\
\text { enterprise survey }\end{array}$ & $\begin{array}{l}5 \text { point (1="no } \\
\text { obstacle"; 5="severe" }\end{array}$ \\
\hline To what degree is/are Tax administration an obstacle to the current operations of this establishment? & $\begin{array}{l}\text { World Bank's } \\
\text { enterprise survey }\end{array}$ & $\begin{array}{l}5 \text { point }(1=" \text { no } \\
\text { obstacle"; 5="severe" }\end{array}$ \\
\hline To what degree is/are Political instability an obstacle to the current operations of this establishment? & $\begin{array}{l}\text { World Bank's } \\
\text { enterprise survey }\end{array}$ & $\begin{array}{l}5 \text { point (1="no } \\
\text { obstacle"; 5="severe" }\end{array}$ \\
\hline To what degree is/are Corruption an obstacle to the current operations of this establishment? & $\begin{array}{l}\text { World Bank's } \\
\text { enterprise survey }\end{array}$ & $\begin{array}{l}5 \text { point (1="no } \\
\text { obstacle"; 5="severe" }\end{array}$ \\
\hline To what degree is/are Courts an obstacle to the current operations of this establishment? & $\begin{array}{l}\text { World Bank's } \\
\text { enterprise survey }\end{array}$ & $\begin{array}{l}5 \text { point (1="no } \\
\text { obstacle"; 5="severe" }\end{array}$ \\
\hline To what degree are Labor Regulations an obstacle to the current operations of this establishment? & $\begin{array}{l}\text { World Bank's } \\
\text { enterprise survey }\end{array}$ & $\begin{array}{l}5 \text { point (1="no } \\
\text { obstacle"; 5="severe" }\end{array}$ \\
\hline To what degree is Electricity an obstacle to the current operations of this establishment? & $\begin{array}{l}\text { World Bank's } \\
\text { enterprise survey }\end{array}$ & $\begin{array}{l}5 \text { point (1="no } \\
\text { obstacle"; 5="severe" }\end{array}$ \\
\hline To what degree is Transport an obstacle to the current operations of this establishment? & $\begin{array}{l}\text { World Bank's } \\
\text { enterprise survey }\end{array}$ & $\begin{array}{l}5 \text { point (1="no } \\
\text { obstacle"; 5="severe" }\end{array}$ \\
\hline To what degree are Practices of Competitors in the Informal Sector an obstacle to the current operations of this establishment? & $\begin{array}{l}\text { World Bank's } \\
\text { enterprise survey }\end{array}$ & $\begin{array}{l}5 \text { point (1="no } \\
\text { obstacle"; 5="severe" }\end{array}$ \\
\hline To what degree is Electricity an obstacle to the current operations of this establishment? & $\begin{array}{l}\text { World Bank's } \\
\text { enterprise survey }\end{array}$ & $\begin{array}{l}5 \text { point (1="no } \\
\text { obstacle"; 5="severe" }\end{array}$ \\
\hline
\end{tabular}


Appendix C: Estimates of Vignette Dummies and Variances in Equation 4

\begin{tabular}{|c|c|c|c|c|c|c|}
\hline & \multicolumn{2}{|l|}{ Credit } & \multicolumn{2}{|l|}{ Electricity } & \multicolumn{2}{|l|}{ PS } \\
\hline & Coefficient & Ranking & Coefficient & Ranking & Coefficient & Ranking \\
\hline Vignette 1 & $\begin{array}{l}-0.254 \\
{[0.093]^{* * *}}\end{array}$ & 1 & $\begin{array}{l}-0.112 \\
{[0.081]}\end{array}$ & 5 & $\begin{array}{l}2.540 \\
{[0.129]^{* * *}}\end{array}$ & 7 \\
\hline Vignette 2 & $\begin{array}{l}-0.187 \\
{[0.092]^{* *}}\end{array}$ & 2 & $\begin{array}{l}0.314 \\
{[0.092]^{* * *}}\end{array}$ & 6 & $\begin{array}{l}1.577 \\
{[0.097]^{* * *}}\end{array}$ & 3 \\
\hline Vignette 3 (Reference) & NA & 3 & NA & 5 & NA & 1 \\
\hline Vignette 4 & $\begin{array}{l}0.292 \\
{[0.096]^{* * *}}\end{array}$ & 4 & $\begin{array}{l}0.564 \\
{[0.088]^{* * *}}\end{array}$ & 7 & $\begin{array}{l}1.939 \\
{[0.113]^{* * *}}\end{array}$ & 4 \\
\hline Vignette 5 & $\begin{array}{l}0.362 \\
{[0.092]^{* * *}}\end{array}$ & 5 & $\begin{array}{l}-1.055 \\
{[0.097]^{* * *}}\end{array}$ & 1 & $\begin{array}{l}-0.033 \\
{[0.085]}\end{array}$ & 1 \\
\hline Vignette 6 & $\begin{array}{l}0.442 \\
{[0.092]^{* * *}}\end{array}$ & 6 & $\begin{array}{l}0.750 \\
{[0.092]^{* * *}}\end{array}$ & 8 & $\begin{array}{l}1.998 \\
{[0.109]^{* * *}}\end{array}$ & 6 \\
\hline Vignette 7 & $\begin{array}{l}0.095 \\
{[0.091]}\end{array}$ & 3 & $\begin{array}{l}-0.332 \\
{[0.084]^{* * *}}\end{array}$ & 4 & $\begin{array}{l}1.959 \\
{[0.108]^{* * *}}\end{array}$ & 5 \\
\hline Vignette 8 & $\begin{array}{l}0.119 \\
{[0.094]}\end{array}$ & 3 & $\begin{array}{l}-0.845 \\
{[0.084] * * *}\end{array}$ & 3 & $\begin{array}{l}1.267 \\
{[0.093]^{* * *}}\end{array}$ & 2 \\
\hline Vignette 9 & $\begin{array}{l}0.029 \\
{[0.095]}\end{array}$ & 3 & $\begin{array}{l}-1.024 \\
{[0.085] * * *}\end{array}$ & 2 & $\begin{array}{l}2.629 \\
{[0.133]^{* * *}}\end{array}$ & 8 \\
\hline Vignette 10 & $\begin{array}{l}0.133 \\
{[0.090]}\end{array}$ & 3 & & & & \\
\hline Vignette 11 & $\begin{array}{l}0.053 \\
{[0.086]}\end{array}$ & 3 & & & & \\
\hline Vignette 12 & $\begin{array}{l}0.488 \\
{[0.088]^{* * *}}\end{array}$ & 7 & & & & \\
\hline $\begin{array}{l}\sigma_{\mathrm{v}} \\
\sigma_{\mathrm{u}}\end{array}$ & $\begin{array}{l}0.793 \\
{[0.037]^{* * *}} \\
0.466 \\
{[0.029]^{* * *}} \\
\end{array}$ & & $\begin{array}{l}0.773 \\
{[0.034]^{* * *}} \\
0.400 \\
{[0.026]^{* * *}}\end{array}$ & & $\begin{array}{l}0.745 \\
{[0.037]^{* * *}} \\
0.528 \\
{[0.032]^{* * *}} \\
\end{array}$ & \\
\hline
\end{tabular}

Standard errors are in brackets. *significant at $10 \%$ level, ** significant at $5 \%$ level, and $* * *$ significant at $1 \%$ level. 
Appendix D: Questionnaire

\section{A. FIRM CHARACTERISTICS}

A1. In what year was this business established?

1. Enter a year [FORMAT: 1999] \{RANGE: $1964-2014\}$

97. Don't know

98. Refuse to answer

A2. In what year was the business officially registered?

1. Enter a year [FORMAT: 1999] \{RANGE: $1964-2014\}$

97. Don't know

98. Refuse to answer

A3. What is the main industrial classification of your business?

1. Crop production

2. Animal production

3. Forestry and logging

4. Construction

5. Manufacturing of food

6. Manufacturing of beverage

7. Manufacturing of textile

8. Manufacturing of wearing apparels

9. Manufacture of wood, of products of wood, and furniture

10. Manufacture of paper and paper products

11. Manufacture of fabricated and metal products

12. Other manufacturing

13. Wholesale and retail trade

14. Wholesale trade alone

15. Retail trade alone

16. Repair, maintenance and servicing of motor vehicles and motorcycles

17. Transportation

18. Educational services

19. Hotels

20. Restaurants

21. Travel and tour

22. Professional, scientific and technical services

23. Other services

24. Gems

25. Other [PLEASE SPECIFY]

97. Don't know

98. Refuse to answer

A4. Does your business import, or export any goods or services, or both? 
1. Import goods or services

2. Export goods or services

3. Import and export goods or services

4. Neither import nor export any goods or services

97. Don't know

98. Refuse to answer

A5. Is your business located in an industrial zone or special economic zone?

1. NO [GO TO B1]

2. YES

97. Don't know

98. Refuse to Answer

A6. In which industrial or special economic zone is it located?

1. Dagon Seikkan Ind. Zone

2. East Dagon Ind. Zone

3. Hlaing Thayar Ind. Zone

4. Mingaladon Ind. Park Co., Ltd.

5. Mingaladon Industrial Park

6. Mingalardon Garden City

7. North Okkalapa Ind. Zone

8. Shwe Lin Ban Ind. Zone

9. Shwe Paukkan Ind. Zone

10. Shwe Pyi Tha Ind. Zone

11. South Dagon Ind. Zone (1)

12. South Dagon Ind. Zone (2)

13. South Dagon Ind. Zone (3)

14. South Okkalarpa Ind. Zone

15. Thaketa Ind. Zone

16. Yangon Industrial Park

17. Other [PLEASE SPECIFY]

97. Don't know

98. Refuse to Answer

99. NA [IF A6=1]

\section{B. OWNER/MANAGER CHARACTERISTICS}

B1. What is your relationship to the business?

1. I am the sole owner

2. I am the sole owner, and hold a managerial position

3. I am a co-owner

4. I am a co-owner, and hold a managerial position

5. I am not an owner, am an employee, and hold a managerial position

6. I am not an owner, am an employee, and don't hold any managerial positions 


\section{Other [PLEASE SPECIFY]}

97. Don't know

98. Refuse to answer

B2. Respondent is

1. Owner/one of the owners [ IF B1=1 2344 ]

2. Not owner [ IF B1=567]

IF B2 $=1$ GO TO B3

IF B2 $=2$ GO TO B12

B3. How did you initially start the business?

1. Founded, or co-founded with others

2. Inherited from parents, or relatives

3. Purchased from other shareholder(s) or previous owner(s)

4. Other [PLEASE SPECIFY]

97. Don't know

98. Refuse to answer

99. NA [IF B2 $=2]$

B4. What percent of the business do you own?

1. Enter a percent $\{$ RANGE: $1-100\}$

97. Don't' know

98. Refuse to answer

99. NA [IF B2=2]

B5. Are you actively involved in managing the day-to-day operations of the business?
1. NO
2. YES
97. Don't know
98. Refuse to answer
99. NA [IF B2=2]

B6. In a typical week, on average, how many hours do you spend on running your business operations?
1. Enter number $\{$ RANGE: $0-95\}$
97. Don't know
98. Refuse to answer
99. NA [IF B2=2]

B7. Before starting this business, did you have work experiences?
1. NO [GO TO B10]
2. YES
97. Don't know
98. Refuse to answer
99. NA [IF B2=2] 
B8. Before starting this business, how many years of work experiences did you have?
1. Enter a number $\{$ RANGE: $1-95\}$
97. Don't know
98. Refuse to answer
99. NA [IF B7 $=1$ OR B2=2]

B9. Did you accumulate these experiences in the same industrial sector as the current business?
1. NO
2. YES
97. Don't know
98. Refuse to answer
99. NA [IF B7=1 OR B2=2]

B10. Before starting this business, did you own a business?
1. NO [GO TO B18]
2. YES
97. Don't know
98. Refuse to answer
99. NA [IF B2=2]

B11. Did the business you owned prior to establishing this business produce or provide the same goods, or (and) services as the current business does?
1. NO
2. YES
97. Don't know
98. Refuse to answer
99. NA [IF B10=1 OR B2=2]

\section{GO TO B18}

B12. How did the owner(s) initially start the business?

1. Founded, or co-founded with others

2. Inherited from parents, or relatives

3. Purchased from other shareholder(s) or previous owner(s)

4. Other [PLEASE SPECIFY]

97. Don't know

98. Refuse to answer

99. NA [IF B2=1]

B13. Before joining this business, did you have work experiences?
1. NO [GO TO B16]
2. YES
97. Don't know
98. Refuse to answer
99. NA [IF B2=1] 
B14. Before joining this business, how many years of work experiences did you have?
1. Enter a number $\{$ RANGE: $1-95\}$
97. Don't know
98. Refuse to answer
99. NA [IF B2=1 OR B13=1]

B15. Did you accumulate these experiences in the same industrial sector as the current business?
1. NO
2. YES
97. Don't know
98. Refuse to answer
99. $\mathrm{NA}[\mathrm{IFB} \mathrm{B} 2=1 \mathrm{OR} \mathrm{B} 13=1]$

B16. Before joining this business, did you own a business?
1. NO [GO TO B18]
2. YES
97. Don't know
98. Refuse to answer
99. NA [IF B2=1]

B17. Did the business you owned prior to joining this business produce or provide the same goods, or (and) services as the current business does?
1. NO
2. YES
97. Don't know
98. Refuse to answer
99. NA [IF B2=1 OR B16=1

B18. Which of the following categories best describe your ethnicity?

[NOTE: IF A RESPONDENT CLAIMS MORE THAN ONE ETHNICITY, PLEASE ASK

HIM/HER THE ETHNICITY HE/SHE MOST ASSOCIATES HIM/HERSELF WITH]

1. Kachin
2. Kayah
3. Kayin
4. Chin
5. Mon
6. Burmese
7. Rakhine
8. Shan
9. Chinese
10. Indian
11. Other
97. Don't know
98. Refuse to answer


B19. What was your father's main occupation?

1. Run own/family business

2. Civil servant

3. Employee in non-government sector

4. Day laborer

5. Farmer

6. Other

97. Don't know

98. Refuse to answer

B20. What was your mother's main occupation?

1. Run own/family business

2. Civil servant

3. Employee in non-government sector

4. Day laborer

5. Farmer

6. Housewife

7. Other

97. Don't know

98. Refuse to answer

B21. Did you grow up in a family that owned any businesses?
1. NO
2. YES
97. Don't know
98. Refuse to answer

B22. What is the highest level of education you have attained?

1. No formal education

2. Primary school (1-4)

3. Secondary school (5-8)

4. High school graduate

5. Government technical high school or other vocational training schools

6. Diploma

7. Some university, but no degree

8. Bachelor's degree (e.g. BA, BE, BS, etc...)

9. Master's degree (e.g. MSc, MA, MBA, etc...)

10. Professional degree (e.g. LL.B, MBBS, etc...)

11. Doctorate degree (e.g. $\mathrm{PhD})$

97. Don't know

98. Refuse to answer

B23. What is your age?

1. Actual age $\{$ RANGE: $15-95\}$

97. Don't know

98. Refuse to answer 
B24. Gender of respondent

\section{Male}

2. Female

B25. What is your marital status?

1. Married

2. Single

97. Don't know

98. Refuse to answer

B26. Is this business either partially or fully owned by foreigner(s)?

1. NO [GO TO B28]

2. YES

97. Don't know

98. Refuse to answer

B27. What percent of the company is owned by foreigner(s)?

1. Enter a percent $\{$ RANGE: $1-100\}$

97. Don't know

98. Refuse to answer

99. NA [IF B26=1]

B28. Are you a citizen of Myanmar?

1. NO

2. YES [GO TO B30]

97. Don't know

98. Refuse to answer

B29. What is your nationality?

1. Australia

2. European countries

3. India

4. Japan

5. Korea

6. Laos

7. Malaysia

8. New Zealand

9. Singapore

10. Thailand

11. USA

12. Vietnam

13. Other [PLEASE SPECIFY]

97. Don't Know

98. Refuse to answer

99. NA [B28=2] 
If $\mathrm{B} 2=2 \mathrm{GO}$ TO B32

B30. Besides you, are there any others who also own this business?

1. NO [GO TO C1]
97. YES Don't know
98. Refuse to answer
99. NA [IF B2=2]

B31. How many others also own this business?

1. Enter a number $\{$ RANGE:1-50\}

2. The business is owned by a parent company, a financial institution, an organization, etc... [ GO TO C1]

97. Don't know

98. Refuse to answer

99. NA [B30 $=1$ OR B2 $=2]$

B32. Indicate the percent of ownership information, relationship to the business, relationship to you, and involvement in the business per week for up to 3 owners owning the largest percent of the business individually [IN ADDITION TO THE RESPONDENT IF B2=1]

\begin{tabular}{|c|c|c|c|c|}
\hline & a. Percent & $\begin{array}{l}\text { b. Relationship to the } \\
\text { business }\end{array}$ & $\begin{array}{l}\text { c. Relationship to } \\
\text { you }\end{array}$ & $\begin{array}{l}\mathrm{d} \text {. Involvement in the } \\
\text { business per week }\end{array}$ \\
\hline & $\begin{array}{l}\text { 1. Percent } \\
\text { \{RANGE } \\
: 1-100\} \\
\text { 99. NA }\end{array}$ & $\begin{array}{l}\text { 1. co-owner } \\
\text { 2. co-owner, and } \\
\text { holds a managerial } \\
\text { position } \\
\text { 97. Don't know } \\
\text { 98. Refuse to answer } \\
\text { 99. NA }\end{array}$ & $\begin{array}{ll}\text { 1. } & \text { Spouse } \\
\text { 2. } & \text { Child } \\
\text { 3. } & \text { Parents } \\
\text { 4. Relative } \\
\text { 5. } \text { Business } \\
\text { partner/friend } \\
\text { 6. Boss [If B2=2] } \\
\text { 7. Other [PLEASE } \\
\text { SPECIFY] } \\
\text { 97. Don't know } \\
\text { 98. Refuse to } \\
\text { answer } \\
\text { 99. NA }\end{array}$ & $\begin{array}{l}\text { 1. } 0 \text { hour } \\
\text { 2. Less than } 20 \text { hours } \\
\text { 3. } 20 \text { to } 40 \text { hours } \\
\text { 4. } 41 \text { hours and above } \\
\text { 97. Don't know } \\
\text { 98. Refuse to answer } \\
\text { 99. NA }\end{array}$ \\
\hline \multicolumn{5}{|l|}{ 1. First owner } \\
\hline \multicolumn{5}{|l|}{$\begin{array}{l}\text { 2. Second } \\
\text { owner }\end{array}$} \\
\hline 3. Third owner & & & & \\
\hline
\end{tabular}

[B4 AND SUM OF COLUMN B32a SHOULD ADD UP CLOSE TO 100\%]

C. SALES 
C1. From Jan 2013 to Dec 2013, did you sell your business's goods and (or) services to other countries?

1. NO [GO TO C5]

2. YES

97. Don't know

98. Refuse to answer

C2. From Jan 2013 to Dec 2013, which of the following countries represents your business's largest exports of goods and (or) services?

1. Australia
2. European countries
3. India
4. Japan
5. Korea
6. Laos
7. Malaysia
8. New Zealand
9. Singapore
10. Thailand
11. USA
12. Vietnam
13. Other [PLEASE SPECIFY]
97. Don't Know
98. Refuse to answer

C3. From Jan 2013 to Dec 2013, what are the total number of international buyers that bought your business's goods and (or) services?

[INTERNATIONAL BUYERS CAN BE BUSINESSES, ORGANIZATIONS, GOVERNMENT ENTITIES, OR INDIVIDUALS]

1. Enter a number $\{$ RANGE: $1-1000\}$

97. Don't know

98. Refuse to answer

99. NA [IF $\mathrm{C} 1=1]$

C4. From Jan 2013 to Dec 2013, what percentage of your business's total sales of goods and (or) services was exported to other countries?

1. Enter a percent $\{$ RANGE: $1-100\}$

97. Don't know

98. Refuse to answer

99. NA [IF C1=1]

C5. From Jan 2013 to Dec 2013, what percent of your business's total sales of goods and (or) services was bought by the central, state, and (or) local government?

1. Enter a percent $\{$ RANGE: $0-100$ \}

97. Don't know 
C6. From Jan 2013 to Dec 2013, what percentage of your business's total sales of goods and (or) services was bought by other businesses, or organizations in local markets?
1. Enter a percent $\{$ RANGE: $0-100\}$
97. Don't know
98. Refuse to answer

C7. From Jan 2013 to Dec 2013, what percentage of your business's total sales of goods and (or) services was bought by individual consumers in local markets?
1. Enter a percent $\{$ RANGE: $0-100\}$
97. Don't know
98. Refuse to answer

C8. As of today, how many competitors are there offering the same product(s) or service(s) as your business does?

1. Enter a number $\{$ RANGE: $0-1000\}$

97. Don't know

98. Refuse to answer

C9. Since starting this business, has your business ever sold goods and (or) services to central, state, and (or) local government directly?
1. NO [GO TO C11]
2. YES
97. Don't know
98. Refuse to answer

C10. Since starting this business, how many years in total has your business sold goods and (or) services to central, state, and (or) local government directly? [EVEN ONE SALE IN ANY CALENDAR YEAR SHALL BE COUNTED AS ONE YEAR]
1. Enter a number $\{$ RANGE: $1-30\}$
97. Don't know
98. Refuse to answer
99. NA [IF C9=1]

C11. From Jan 2013 to Dec 2013, which of the following category best represents your business's total sales of goods and (or) services? [1 Lakh $=100000$ Kyat $=$ US $\$ 100]$
1. Less than 5,00 Lakhs
2. 500 Lakhs -749 Lakhs
3. 750 Lakhs -999 Lakhs
4. 1000 Lakhs -1449 Lakhs
5. 1500 Lakhs -1999 Lakhs
6. 2000 Lakhs -2499 Lakhs
7. 2500 Lakhs -2999 Lakhs
8. 3000 Lakhs -3999 Lakhs
9. 4000 Lakhs -4999 Lakhs 

10. 5000 Lakhs -7499 Lakhs
11. 7500 Lakhs - 9999 Lakhs
12. Over 10000 Lakhs
97. Don't Know
98. Refuse to answer

C12. From Jan 2012 to Dec 2012, which of the following category best represents your business's total sales of goods and (or) services? [1 Lakh=100000 Kyat=US\$100]

1. Less than 5,00 Lakhs

2. 500 Lakhs -749 Lakhs

3. 750 Lakhs -999 Lakhs

4. 1000 Lakhs -1449 Lakhs

5. 1500 Lakhs -1999 Lakhs

6. 2000 Lakhs -2499 Lakhs

7. 2500 Lakhs -2999 Lakhs

8. 3000 Lakhs - 3999 Lakhs

9. 4000 Lakhs -4999 Lakhs

10. 5000 Lakhs - 7499 Lakhs

11. 7500 Lakhs - 9999 Lakhs

12. Over 10000 Lakhs

97. Don't Know

98. Refuse to answer

D. CAPITAL AND CREDIT

D1. What were the main sources of capital used to start the business? [PLEASE CHECK ALL THAT APPLY]

1. Personal or family savings, personal or family assets
3. Pooling funds among business partners, or friends
4. Loans from friends, relatives, or business partners
5. Start-up capital not required because inherited the business from parents,
relatives, or friends
6. Other [PLEASE SPECIFY]
97. Don't know

D2. From Jan 2012 to Dec 2013, what were your business's main sources of capitals used to finance business operations, or expansion? [PLEASE CHECK ALL THAT APPLY]

1. Retained profits, and business assets

2. Personal/family saving(s) of owners and assets

3. Loans from friends, relatives, or other business partners

4. Private Bank Loans

5. Loans from government

6. Others [PLEASE SPECIFY]

97. Don't know 
D3. From Jan 2012 to Dec 2013, how many bank loan applications did the business submit? [INCLUDE BOTH THOSE REJECTED AND APPROVED]

1. $0[\mathrm{GO}$ TO D7]

2. 1

3. 2

4. 3

5. 4

6. 5

7. 6

8. 7

9. 8

10. 9

11. 10

12. 11

13. 12

14. 13 and above

97. Don't' know

98. Refuse to answer

D4. From Jan 2012 to Dec 2013 , how many of the bank loan applications were approved?

1. 0
3.2
4.3
5.4
6.5
7.6
8.7
9.8
10.9
11.10
12.11
13. 12
14. 13 and above
97. Don't' know
98. Refuse to answer
99. NA [IF D3=-1]

[CHECK IF D4<=D3]

[IF D4=D3, GO TO D6]

D5. From Jan 2012 to Dec 2013, what were the primary reasons some [ALL] of the loans applied were rejected? [PLEASE CHECK ALL THAT APPLY]

1. Insufficient value of collateral

2. Didn't have the collateral banks asked for 
3. Other [PLEASE SPECIFY]

97. Don't' know

98. Refuse to answer

99. NA [IF D3==1 OR D4=D3]

[IF D4=1, GO TO D8] 
D6. Please enter information for each of the following loans approved between Jan 2012 and Dec 2013 ?

\begin{tabular}{|c|c|c|c|c|c|c|c|c|c|}
\hline & $\begin{array}{l}\text { a. Loan } \\
\text { amount in } \\
\text { Kyat } \\
\text { [Lakhs] }\end{array}$ & $\begin{array}{l}\text { b. Number of } \\
\text { collateralized } \\
\text { assets required }\end{array}$ & $\begin{array}{l}\text { c. Types of } \\
\text { collateralized assets } \\
\text { required [PLEASE } \\
\text { CHECK ALL THAT } \\
\text { APPLY] }\end{array}$ & $\begin{array}{l}\text { d. Total values of } \\
\text { collateralized } \\
\text { assets required }\end{array}$ & $\begin{array}{l}\text { e. How collaterals were } \\
\text { initially acquired } \\
\text { [PLEASE CHECK } \\
\text { ALL THAT APPLY] }\end{array}$ & $\begin{array}{l}\text { f. Loan period in } \\
\text { year }\end{array}$ & g. Interest rate & $\begin{array}{l}\text { h. Year } \\
\text { approved }\end{array}$ & i. How it was used \\
\hline & $\begin{array}{l}\text { 1. Enter a } \\
\text { number } \\
\text { 97. Don't know } \\
\text { 98. Refuse to } \\
\text { answer } \\
\text { 99. NA }\end{array}$ & $\begin{array}{l}\text { 1. Number of } \\
\text { collateralized } \\
\text { assets } \\
\text { required } \\
\text { 97. Don't know } \\
\text { 98. Refuse to } \\
\text { answer } \\
\text { 99. NA }\end{array}$ & $\begin{array}{l}\text { 1. House sitting on a } \\
\text { land owned by } \\
\text { owner } \\
\text { 2. Empty land owned } \\
\text { by owner } \\
\text { 3. Other [PLEASE } \\
\text { SPECIFY] } \\
\text { 97. Don't' know } \\
\text { 98. Refuse to answer } \\
\text { 99. NA }\end{array}$ & $\begin{array}{l}\text { 1. Total values } \\
\text { 97. Don't' know } \\
\text { 98. Refuse to } \\
\text { answer } \\
\text { 99.NA }\end{array}$ & $\begin{array}{l}\text { 1. Inherited from } \\
\text { parents/relatives } \\
\text { 2. Owner bought/built it } \\
\text { 3. Other [PLEASE } \\
\text { SPECIFY] } \\
\text { 97. Don't' know } \\
\text { 98. Refuse to answer } \\
\text { 99.NA }\end{array}$ & $\begin{array}{l}\text { 1. Enter a number } \\
\text { 97. Don't' know } \\
\text { 98. Refuse to } \\
\text { answer } \\
\text { 99. NA }\end{array}$ & $\begin{array}{l}\text { 1. Enter a } \\
\text { number } \\
\text { 97. Don't' } \\
\text { know } \\
\text { 98. Refuse to } \\
\text { answer } \\
\text { 99. NA }\end{array}$ & 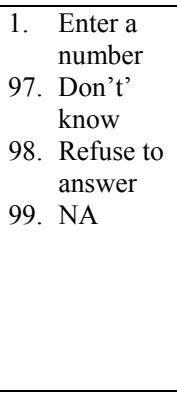 & $\begin{array}{l}\text { 1. To finance business } \\
\text { expansion } \\
\text { 2. To finance acquisition of } \\
\text { new capitals/improving } \\
\text { existing capitals } \\
\text { 3. To finance regular business } \\
\text { operations } \\
\text { 4. To pay back existing debt } \\
\text { 5. Other [PLEASE SPECIFY] } \\
\text { 97. Don't know } \\
\text { 98. Refuse to answer } \\
\text { 99. NA }\end{array}$ \\
\hline \multicolumn{10}{|l|}{ 1. Largest loan } \\
\hline \multicolumn{10}{|l|}{ 2. Second largest loan } \\
\hline 3. Third largest loan & & & & & & & & & \\
\hline
\end{tabular}

\section{[A HOUSE SITTING ON A LAND IS CONSIDERED ONE ASSET]}

[GO TO D8]

a. Total amount of the [largest/second largest/third largest] loan in Lakhs approved between Jan 2012 and Dec 2013 \{RANGE: $0-100000\}$

b. Total number of collateralized assets required for the [largest/second largest/third largest] loan approved between Jan 2012 and Dec 2013 RANGE: 0 - 10$\}$

c. Types of collateralized assets required for the [largest/second largest/third largest] loan approved between Jan 2012 and Dec 2013

d. Total values of collateralized assets in Lakhs required for the [largest/second largest/third largest] loan approved between Jan 2012 and Dec 2013 \{RANGE: 0 - 500000\}

e. How the collateralized assets required for the [largest/second largest/third largest] loan approved between Jan 2012 and Dec 2013 were initially acquired?

f. Loan period in months for the [largest/second largest/third largest] loan approved between Jan 2012 and Dec 2013 \{RANGE: $1-120\}$

g. Interest rate per year for the [largest/second largest/third largest] loan approved between Jan 2012 and Dec 2013 \{RANGE:0$100\}$

h. Year the [largest/second largest/third largest] loan was approved \{RANGE: $2012-2013$ \} 
i. How the [largest/second largest/third largest] loan approved between Jan 2012 and Dec 2013 was used? 
D7. What were the primary reasons not applying for any bank loans between Jan 2012 and Dec 2013? [PLEASE CHECK ALL THAT APPLY]

1. Didn't understand or not familiar with the procedures to apply for bank loans

2. Bank loan procedures were lengthy and complicated

3. Didn't have the collateral banks required

4. Not enough collateral value

5. Didn't need a bank loan

6. Other [PLEASE SPECIFY]

97. Don't' know

98. Refuse to answer

99. NA [IF D3!=1]

D8. Since starting this business, has your business ever been granted any bank loans to finance your business operations, or expansion?
1. NO [GO TO D10]
2. YES
97. Don't' know
98. Refuse to answer

D9. Since starting this business, how many total bank loans has your business been granted?

1. Enter a number $\{$ RANGE: $1-95\}$

97. Don't' know

98. Refuse to answer

99. NA [IF D8=1]

D10. From Jan 2012 to Dec 2013, did you ever try to get any loans from friends or relatives for your business?
1. NO [GO TO D14]
2. YES
97. Don't know
98. Refuse to answer

D11. From Jan 2012 to Dec 2013, how many times did you try to get loans from friends or relatives?
1. Enter a number $\{$ RANGE:1-95\}
97. Don't know
98. Refuse to answer
99. NA [IF D10=1]

D12. From Jan 2012 to Dec 2013, how many loans did you actually get from friends or relatives?

1. Enter a number $\{$ RANGE:0-95\}

97. Don't know

98. Refuse to answer

99. NA [IF D10=1] 


\section{CHECK [IF D12<=D11] \\ IF D12=0 GO TO D14}

D13. Please enter information for each of the following loans received from friends or relatives between Jan 2012 and Dec 2013?

\begin{tabular}{|c|c|c|c|}
\hline & $\begin{array}{l}\text { a. Loan amount in Kyat } \\
\text { [Lakhs] }\end{array}$ & b. If collateral required & c. Interest rate per month \\
\hline & $\begin{array}{l}\text { 1. } \begin{array}{l}\text { Enter a number } \\
\text { \{RANGE: } 1-100000\}\end{array} \\
\text { 97. Don't know } \\
\text { 98. Refuse to answer } \\
\text { 99. NA }\end{array}$ & $\begin{array}{ll}\text { 1. } & \text { NO } \\
\text { 2. } & \text { YES } \\
\text { 97. Don't know } \\
\text { 98. Refuse to answer } \\
\text { 99. NA }\end{array}$ & $\begin{array}{ll}\text { 1. } & \text { Enter a number } \\
\text { \{RANGE:0-30\} } \\
\text { 97. Don't know } \\
\text { 98. Refuse to answer } \\
\text { 99. NA }\end{array}$ \\
\hline \multicolumn{4}{|l|}{ 1. Largest loan } \\
\hline \multicolumn{4}{|l|}{ 2. Second largest loan } \\
\hline 3. Third largest loan & & & \\
\hline
\end{tabular}

D14. Overall, how difficult is it for you to borrow money for your business expansion?

1. No difficulty
2. Mild difficulty
3. Moderate Difficulty
4. Major difficulty
5. Severe difficulty
97. Don't know
98. Refuse to answer

We will show you 3 examples of business owners with varying difficulty in borrowing money for business expansion. You will evaluate on a 5-point scale how difficult it is for them to borrow money. Please evaluate each of them in the same manner that you will evaluate yourselves.

D15. U Ko Ko owns a service business. To expand his business, he has received a loan worth US\$ 30,000 from a relative at 18\% APR (1.5\% per month) without collateral. Repayment timeframe is flexible. He is not qualified for any bank loans.

Overall, how difficult is it for U Ko Ko to borrow money for his business expansion?

2. Mo difficulty
3. Moderate difficulty
4. Major difficulty
5. Severe difficulty
97. Don't know
98. Refuse to answer

D16. U Soe Aung owns a logging business. To expand his business, he has received a loan worth US\$ 30,000 from a friend at 24\% APR (2\% per month) without collateral. Repayment timeframe is flexible. He is not qualified for any bank loans. 
How difficult is it for U Soe Aung to borrow money for his business expansion?
1. No difficulty
2. Mild difficulty
3. Moderate difficulty
4. Major difficulty
5. Severe difficulty
97. Don't know
98. Refuse to answer

D17. U Lwin Aung owns a factory. To expand his business, he has received a loan worth US\$ 30,000 from a friend at $36 \%$ APR ( $3 \%$ per month) without collateral. Repayment timeframe is flexible. He is not qualified for any bank loans.

How difficult is it for U Lwin Aung to borrow money for his business expansion?
1. No difficulty
2. Mild difficulty
3. Moderate difficulty
4. Major difficulty
5. Severe difficulty
97. Don't know
98. Refuse to answer

D18. U Moe Gyi owns a factory. To expand his business, he has received a loan worth US\$ 30,000 from a friend at $48 \%$ APR (4\% per month) without collateral. Repayment timeframe is flexible. He is not qualified for any bank loans.

How difficult is it for U Moe Gyi to borrow money for his business expansion?
1. No difficulty
2. Mild difficulty
3. Moderate difficulty
4. Major difficulty
5. Severe difficulty
97. Don't know
98. Refuse to answer

D19. U Myo Win owns a construction company and wants to build a new apartment building. He has received a bank loan worth US\$100,000 at 13\% APR to finance the construction with his real estate worth US\$100,000 as collateral. The loan needs to be repaid one year after it is issued. He can't borrow that amount from friends or relatives.

Overall, how difficult is it for U Myo Win to borrow money for his business expansion?
1. No difficulty
2. Mild difficulty
3. Moderate difficulty
4. Major difficulty
5. Severe difficulty
97. Don't know 
D20. Ko Zaw Zaw owns a service business. To expand his business, he has received a bank loan worth US\$ 100,000 at $13 \%$ APR with his real estate worth US\$200,000 as collateral. The loan needs to be fully repaid within 1 year after it is issued. He can't borrow that amount from friends or relatives.

How difficult is it for Ko Zaw Zaw to borrow money for his business expansion?
1. No difficulty
2. Mild difficulty
3. Moderate difficulty
4. Major difficulty
5. Severe difficulty
97. Don't know
98. Refuse to answer

D21. U Aung Aung owns a wholesale business. To expand his business, he has received a bank loan worth US\$100,000 at 13\% APR with his apartment worth US\$200,000 as collateral. The loan needs to be fully repaid one year after it is issued. He can't borrow that amount from friends or relatives.

How difficult is it for $\mathrm{U}$ Aung Aung to borrow money for his business expansion?
1. No difficulty
2. Mild difficulty
3. Moderate difficulty
4. Major difficulty
5. Severe difficulty
97. Don't know
98. Refuse to answer

D22. Ko Oo owns a crane rental business. To finance acquisition of a new crane, he has received a bank loan worth US\$100,000 at 13\% APR with his real estate worth US\$300,000 as collateral. The loan needs to be fully repaid within 1 year after it is issued. He can't borrow that amount from friends or relatives.

How difficult is it for Ko Oo to borrow money for his business expansion?

1. No difficulty
2. Mild difficulty
3. Moderate difficulty
5. Major difficulty
97. Dovere difficulty
98. Refuse to answer

D23. Ko Naing Kyaw Win operates a travel business. To finance acquisition of 3 new tour buses, she has received a loan worth US $\$ 100,000$ at $13 \%$ APR from the recently created 
SME Bank without collateral. The loan needs to be repaid one year after it is issued. She can't borrow from friends or relatives.

How difficult is it for Ko Naing Kyaw Win to borrow money for his business expansion?
1. No difficulty
2. Mild difficulty
3. Moderate difficulty
4. Major difficulty
5. Severe difficulty
97. Don't know
98. Refuse to answer

D24. Ko Zaw Thet owns a service business. To expand his business, he has to use retained profits and personal savings. He is not qualified for a bank loan, and can't borrow from friends or relatives either.

How difficult is it for Ko Zaw Thet to borrow money for his business expansion?
1. No difficulty
2. Mild difficulty
3. Moderate difficulty
4. Major difficulty
5. Severe difficulty
97. Don't know
98. Refuse to answer

D25. U Win Naing owns a trading business. To expand his business, he has received a loan worth US\$ 30,000 from a friend at 24\% APR (2\% per month) with his apartment as collateral. Repayment timeframe is flexible. He is not qualified for any bank loans.

How difficult is it for U Win Naing to borrow money for his business expansion?
1. No difficulty
2. Mild difficulty
3. Moderate difficulty
4. Major difficulty
5. Severe difficulty
97. Don't know
98. Refuse to answer

D26. U Chit Tun owns a service business. To expand his business, he has received a loan worth US\$ 30,000 from a friend at 36\% APR (3\% per month) with his apartment as collateral. Repayment timeframe is flexible. He is not qualified for any bank loans.

How difficult is it for U Chit Tun to borrow money for his business expansion?

1. No difficulty

2. Mild difficulty 
3. Moderate difficulty

4. Major difficulty

5. Severe difficulty

97. Don't know

98. Refuse to answer

\section{E. ACCESS TO ELECTRICITY}

E1. In the past 12 months, did you apply for a new electricity connection for your business?
1. No [GO TO E7]
2. Yes
97. Don't know
98. Refuse to answer

E2. What is the status of the application?

1. Pending [GO TO E3]

2. Approved [GO TO E4]

3. Rejected [GO TO E7]

97. Don't know

98. Refuse to answer

99. $\mathrm{NA}[\mathrm{E} 1=1 \mathrm{OR} \mathrm{E} 2=2 \mathrm{OR} \mathrm{E} 2=3]$

E3. How long in days has it been since you submitted the application if it is pending?

1. Enter a number $\{$ RANGE: $1-365\}$

97. Don't know

98. Refuse to answer

99. NA $[E 1=1$ OR E2=2 OR E2=3]

[GO TO E7]

E4. How long did it take in days from the date you submitted the application to the date you could begin to use the electricity officially?

1. Enter number of days $\{\mathrm{RANGE}: 0-365\}$

97. Don't know

98. Refuse to answer

99. NA [E1=1 OR E2=1 OR E2=3]

E5. Did you have to buy a transformer for the new electricity connection you applied in the past 12 months?
1. $\mathrm{NO}$
2. YES
97. Don't know
98. Refuse to answer
99. NA [E1=1 OR E2=1 OR E2=3]

E6. How much did the new electricity connection cost you in Kyat [Lakhs] including transformer cost, if any? 


\section{Enter an amount in Kyat [Lakhs] \{RANGE: $1-1000\}$ \\ 97. Don't know \\ 98. Refuse to answer \\ 99. NA $[\mathrm{E} 1=1$ OR E2=1 OR E2=3]}

E7. Did your business experience any power outage in a typical month in year 2013?
1. NO [GO TO E10]
2. YES
97. Don't know
98. Refuse to answer

E8. In a typical month in year 2013, how many times did your business experience power outage?
1. Enter a number $\{$ RANGE: $1-100\}$
97. Don't know
98. Refuse to answer
99. NA [IF E7=1]

E9. On average how many hours did an outage last in a typical month in 2013 ?
1. Enter a number $\{\mathrm{RANGE}: 1-48\}$
97. Don't know
98. Refuse to answer
99. NA [IF E7=1]

E10. Does your business currently own or use a generator?
1. NO [GO TO E13]
2. YES
97. Don't know
98. Refuse to answer

E11. In a typical month, on average, how many times do you have to operate the generator due to outage or insufficient electricity voltage?
1. Enter a number $\{$ RANGE: $0-100\}$
97. Don't know
98. Refuse to answer
99. NA $[$ IF E10=1]

E12. On average, how many hours do you have to run the generator each time due to outage or insufficient supply?
1. Enter a number $\{$ RANGE: $0-48\}$
97. Don't know
98. Refuse to answer
99. NA [IF E10=1]

E13. Overall, how difficult is it to have access to electricity for your business?

1. No difficulty 


2. Mild difficulty
3. Moderate difficulty
4. Major difficulty
5. Severe difficulty
97. Don't know
98. Refuse to answer

We will now show you 3 examples of business owners with varying degrees in getting access to electricity. You will evaluate on a 5-point scale how difficult it is for them to get access to electricity. Please evaluate each of them in the same manner that you will evaluate yourselves.

E14. It took U Min Min 3 months to get a new connection to electricity for his new warehouse. He paid US\$25,000 in connection fees, and US\$ 12,000 for a transformer.

How difficult is it for U Min Min to get access to electricity for his business?

1. No difficulty
2. Mild difficulty
3. Moderate difficulty
5. Major difficulty
97. Devere difficulty
98. Refuse to answer

E15. Ko Naing owns a factory located in an industrial zone. Due to power outages or insufficient electrical voltage, his factory has to operate a generator 6 hours a day to power the factory operations.

How difficult is it for Ko Naing to get access to electricity for his business?
1. No difficulty
2. Mild difficulty
3. Moderate difficulty
4. Major difficulty
5. Severe difficulty
97. Don't know
98. Refuse to answer

E16. U Kyi owns a printing business. Due to low electricity voltage, his business has to operate a generator 4 hours a day to power the printing machine.

How difficult is it for U Kyi to get access to electricity for his business?

1. No difficulty
3. Mild difficulty
3. Moderate difficulty
4. Major difficulty
5. Severe difficulty
97. Don't know


E17. U Yin Aung owns a brick factory. Due to the lack of electricity supply, he has to use a power generator to fully power his factory operations.

How difficult is it for U Yin Aung to get access to electricity for his business?
1. No difficulty
2. Mild difficulty
3. Moderate difficulty
4. Major difficulty
5. Severe difficulty
97. Don't know
98. Refuse to answer

E18. U Aung Aung owns an export/import business. Due to low electricity voltage, his office sometimes has to operate generator mainly to power air conditioners.

How difficult is it for U Aung Aung to get access to electricity for his business?
1. No difficulty
2. Mild difficulty
3. Moderate difficulty
4. Major difficulty
5. Severe difficulty
97. Don't know
98. Refuse to answer

E19. Ko Htoo is the owner of a factory. Due to low electricity voltage, he has to operate a generator for 8 hours a day to power the machine tools for almost every day.

How difficult is it for Ko Htoo to get access to electricity for his factory?
1. No difficulty
2. Mild difficulty
3. Moderate difficulty
4. Major difficulty
5. Severe difficulty
97. Don't know
98. Refuse to answer

E20. Ko Zaw Thet is the owner of a newly established service business. Since his application for a connection to new electricity is still pending, his office has been sharing electricity with a neighboring office temporarily until the application is approved.

How difficult is it for Ko Zaw Thet to get access to electricity for his factory?

2. Mo difficulty
3. Moderate difficulty
4. Major difficulty
5. Severe difficulty
97. Don't know
98. Refuse to answer


E21. Ko Win owns a trading business. His office experiences power outage lasting an hour on average every day. His office doesn't own a power generator and has to operate the business without electricity during outage.

How difficult is it for Ko Win to get access to electricity for his office?
1. No difficulty
2. Mild difficulty
3. Moderate difficulty
4. Major difficulty
5. Severe difficulty
97. Don't know
98. Refuse to answer

E22. U Hlaing owns a garment factory. His factory seldom experiences power outage and the electrical voltage is sufficient for the factory to operate.

How difficult is it for U Hlaing to get access to electricity for his office?

1. No difficulty
3. Mild difficulty
4. Moderate difficulty
5. Sevor difficulty
97. Don't know
98. Refuse to answer

\section{F. ACCESS TO PUBLIC SERVICES}

F1. In the past 6 months, did either you or your staff make any trips to Nay Pyi Taw to complete administrative work, attend meetings, or meet officials?
1. NO [GO TO F6]
2. YES
97. Don't know
98. Refuse to answer

F2. In the past 6 months, how many total trips on average did either you or any of your staff (regardless of positions) make to Nay Pyi Taw to complete administrative work, attend meetings, or meet officials?
1. Enter a number $\{$ RANGE: $1-100\}$
97. Don't know
98. Refuse to answer
99. NA [IF F1=1]

F3. Which of the following represents the business activity you did at Nay Pyi Taw? [PLEASE CHECK ALL THAT APPLY]

1. Complete administrative work

2. Meet with officials, or attend meetings, or both 
3. Try to secure new contracts, or business opportunities

4. Other [PLEASE SPECIFY]

97. Don't know

98. Refuse to answer

99. NA $[\mathrm{F} 1=1]$

F4. How many days did each trip last on average including travel time?

1. Enter a number $\{$ RANGE: $1-30\}$

97. Don't know

98. Refuse to answer

99. NA [IF F1=1]

F5. How much did each trip to the capital city cost you on average? That would include travel, food, accommodation, and other business related expenses.

1. Less than US $\$ 200$

2. US\$ 200 to 399

3. US\$ 400 to US\$ 599

4. US\$ 600 to 799

5. US\$ 800 to US\$ 999

6. US\$ 1000 and above

97. Don't know

98. Refuse to answer

99. NA [IF F1=1]

F6. Does your business have a branch office in Nay Pyi Taw?

1. NO

2. YES

97. Don't know

98. Refuse to answer

F7. In the past 6 months, how often did you utilize the service(s) of a third party (or) an agent to complete administrative work in Nay Pyi Taw on your behalf?

1. Always

2. Very often

3. Sometimes

4. Rarely

5. Never

97. Don't know

98. Refuse to answer

F8. Overall, how difficult is it for you to get access to public services for your business?
1. No difficulty
2. Mild difficulty
3. Moderate difficulty
4. Major difficulty
5. Severe difficulty 
We will now show you 3 examples of business owners with varying degree of access to public services for their businesses. You will evaluate on a 5-point scale how difficult it is for them to get access to public services. Please evaluate each of them in the same manner that you will evaluate yourselves.

F9. It cost Daw Nu US\$ 1,200 in registration fees, took her 2 months, and involved 11 official procedures to formally register her business.

Overall, how difficult is it for Daw Nu to get access to public services for her business?
1. No difficulty
2. Mild difficulty
3. Moderate difficulty
4. Major difficulty
5. Severe difficulty
97. Don't know
98. Refuse to answer

F10. It cost Ma Kay Thi US\$ 1,200 in registration fees, took her 3 days, and involved 2 official procedures to formally register her business.

Overall, how difficult is it for Ma Kay Thi to get access to public services for her business?
1. No difficulty
2. Mild difficulty
3. Moderate difficulty
4. Major difficulty
5. Severe difficulty
97. Don't know
98. Refuse to answer

F11. Ko Tony can complete all the administrative and paper work for his business operations in Yangon, no longer needs to travel to Nay Pyi Taw as he did before, and can pay the applications fees at any private banks.

Overall, how difficult is it for Ko Tony to get access to public services for his business?

2. Mild difficulty
3. Moderate difficulty
4. Major difficulty
5. Severe difficulty
97. Don't know
98. Refuse to answer


F12. Ko Gyi has to make trips to Nay Pyi Taw to complete administrative and paper work for his business operations, because of the unavailability of these public services in Yangon.

Overall, how difficult is it for Ko Gyi to get access to public services for his business?

1. No difficulty

2. Mild difficulty

3. Moderate difficulty

4. Major difficulty

5. Severe difficulty

97. Don't know

98. Refuse to answer

F13. Khaing Khaing can now complete all administrative and paper work online for her business operations, and no longer needs to travel to Nay Pyi Taw as she did before.

Overall, how difficult is it for Khaing Khaing to get access to public services for her business?

1. No difficulty

2. Mild difficulty

3. Moderate difficulty

4. Major difficulty

5. Severe difficulty

97. Don't know

98. Refuse to answer

F14. U Win Oo submits invoices to a government agency every month that require 3 officials' signatures for approval. It takes 2 weeks to get the invoices approved.

Overall, how difficult is it for U Win Oo to get access to public services for his business?

1. No difficulty
3. Mild difficulty
4. Moderate difficulty
5. Sevore difficulty
97. Don't know
98. Refuse to answer

F15. U Toe submits invoices every month to a government agency which requires one official's signature for approval. It takes 2 weeks to get the invoices approved.

Overall, how difficult is it for U Toe to get access to public services for his business?

1. No difficulty

2. Mild difficulty

3. Moderate difficulty

4. Major difficulty

5. Severe difficulty

97. Don't know 
F16. U Ko Ko submits invoices every month to a government agency which requires one official's signature for approval. It takes 2 days to get the invoices approved.

Overall, how difficult is it for U Ko Ko to get access to public services for his business?

1. No difficulty

2. Mild difficulty

3. Moderate difficulty

4. Major difficulty

5. Severe difficulty

97. Don't know

98. Refuse to answer

F17. It has taken Ko Sunny 5 months to get a permit for the construction of his new business warehouse building, costing him US\$ 4500 in application fees.

Overall, how difficult is it for Ko Sunny to get access to public services for his business?

1. No difficulty
2. Mild difficulty
3. Moderate difficulty
5. Major difficulty
97. Dovere difficulty
98. Refuse to answer

G. OVERALL DIFFICULTY

Please rank the following from the most difficult to the least difficult for your business to have access to

Access to funding

Access to electricity

Access to public services for business owners

G1. Most difficult

G2. Second most difficult

G3. Third most difficult

G4. Thinking about access to funding, access to electricity, and access to public services for business owners, overall, how difficult is the business environment for your business expansion?

1. No difficulty

2. Mild difficulty

3. Moderate difficulty

4. Major difficulty

5. Severe difficulty

97. Don't know

98. Refuse to answer 
H1. How many full-time employees does the business currently employ?
1. Enter a number $\{$ RANGE: $>=0\}$
97. Don't know
98. Refuse to answer

H2. How many full-time employees did the business employ when it was first established?
1. Enter a number $\{$ RANGE: $>=0\}$
97. Don't know
98. Refuse to Answer

H3. How many full-time employees did the business employ at the end of year 2012 ?
1. Enter a number $\{$ RANGE: $>=0\}$
97. Don't know
98. Refuse to answer

\section{SUBJECTIVE EXPECTATIONS}

We are going to ask you a few questions about the chance that certain events are going to happen in the coming two years.

There are 10 balls in the bag and I'd like you to pick a few ball(s) out of these 10 balls and put them in each of the bin to express your expected chance that an event will occur to you in the next 12 months. If you don't put any balls in the bin, it suggests you are very sure that this event will not occur in the next 12 months; if you put all the 10 balls in a bin, you are sure that this event will occur. If you put 5 balls, it means it is equally likely an event will occur in the next 12 months as it will not occur. If you put 7 balls, it suggests that this event is more likely to happen than not happen. If you out 1 ball, it means the event is not likely to happen, but is still possible to happen. There is no right or wrong answer. We just want to know what you think that the chance you think that an event will occur in next 12 months.

I1. Please pick numbers of balls and put them in each of the bin to reflect the chance you think it is that

\begin{tabular}{|l|l|l|}
\hline $\begin{array}{l}\text { In the next 12 months, } \\
\text { It will be more difficult } \\
\text { to borrow money from }\end{array}$ & $\begin{array}{l}\text { In the next 12 months, } \\
\text { it will be the same level } \\
\text { of difficulty to borrow } \\
\text { money from a bank as } \\
\text { months }\end{array}$ & $\begin{array}{l}\text { In the next 12 } \\
\text { months, it will be } \\
\text { easier to borrow } \\
\text { the past 12 months } \\
\text { than the past 12 } \\
\text { months }\end{array}$ \\
\hline Bin 1 & Bin 2 & Bin 3 \\
\hline
\end{tabular}

I2. Please pick numbers of balls and put them in each of the bin to reflect the chance you think it is that

\begin{tabular}{|l|l|l|}
\hline $\begin{array}{l}\text { In the next } 12 \text { months, } \\
\text { electricity supply to my }\end{array}$ & $\begin{array}{l}\text { In the next } 12 \text { months, } \\
\text { electricity supply to my }\end{array}$ & $\begin{array}{l}\text { In the next 12 } \\
\text { months, electricity }\end{array}$ \\
\hline
\end{tabular}




\begin{tabular}{|l|l|l|}
\hline $\begin{array}{l}\text { business will be worse } \\
\text { than the past } 12 \text { months }\end{array}$ & $\begin{array}{l}\text { business will be the } \\
\text { same as the past } 12 \\
\text { months }\end{array}$ & $\begin{array}{l}\text { supply to my } \\
\text { business will be } \\
\text { better than the past } \\
12 \text { months }\end{array}$ \\
\hline Bin 1 & Bin 2 & Bin 3 \\
\hline
\end{tabular}

I3. Please pick numbers of balls and put them in each of the bin to reflect the chance you think it is that

\begin{tabular}{|l|l|l|}
\hline $\begin{array}{l}\text { In the next } 12 \text { months, } \\
\text { access to public } \\
\text { services will be worse } \\
\text { than the past } 12 \text { months }\end{array}$ & $\begin{array}{l}\text { In the next } 12 \text { months, } \\
\text { access to public } \\
\text { services will be the } \\
\text { same as the past } 12 \\
\text { months }\end{array}$ & $\begin{array}{l}\text { In the next } 12 \\
\text { months, access to } \\
\text { public services will } \\
\text { be better the past } 12 \\
\text { months }\end{array}$ \\
\hline Bin 1 & Bin 2 & Bin 3 \\
\hline
\end{tabular}

I4. Please pick numbers of balls and put them in each of the bin to reflect the chance you think it is that

\begin{tabular}{|l|l|l|}
\hline $\begin{array}{l}\text { In the next } 12 \text { months, } \\
\text { the business }\end{array}$ & $\begin{array}{l}\text { In the next } 12 \text { months, } \\
\text { the business } \\
\text { environment will be } \\
\text { environment will be the } \\
\text { months }\end{array}$ & $\begin{array}{l}\text { In the next } 12 \\
\text { months, the business } \\
\text { environment will be } \\
\text { better than the past } \\
\text { same as the past } 12 \\
\text { months }\end{array}$ \\
\hline Bin $1 \mathrm{~g}$ & Bin 2 & Bin 3 \\
\hline
\end{tabular}




\title{
ESSAY 2
}

\section{Do Employers In Myanmar Prefer Workers Who Accumulated Skills In More Advanced Countries? Evidence from a Field Experiment}

\author{
Saw Htay Wah
}

\begin{abstract}
This research experimentally investigates the demand for return migrants who accumulate skills in more developed foreign countries in skills-intensive occupations, relative to equivalent workers who accumulate the same skills in local labor markets. While audit studies have provided critical evidence about labor market discrimination in developed countries, I apply this method to the Burmese labor market. I find evidence that foreign experience is favored by employers for certain occupations. Specifically, software developers and programmers with foreign experience, Singapore experience in particular, are highly favored by foreign employers. Among accountants and engineers, I find no systematic and significant difference in callback rates between foreign and local applicants. In addition to foreign experience, I also find differences in callback rates by gender and neighborhood. Specifically, female accountants are highly favored, while female engineers are less favored by employers. As for neighborhood effect, software developers and programmers living in a rich neighborhood receive as many first callbacks from employers as those having Singapore experience. One direct policy implication that arises from findings from this research is that return migration policies targeting specific occupation and employer will be more effective than a single policy targeting all occupations and employers. Since, this is the first labor market audit study performed in a developing country, I also discuss the constraints and challenges that one faces with this type of research in a developing country and then propose measures to overcome these challenges.
\end{abstract}




\section{INTRODUCTION}

In recent years, there has been a growing concern that jobseekers in low-income countries have insufficient skills to meet the needs of hiring employers - a phenomenon referred to as the "skills gap." 15 This is particularly troublesome for low-income countries struggling to develop their economies, as well as for new or growing businesses in those countries trying to operate competitively at a global level. Economic consequences of the skills gap can manifest for both the employers, whose productivity will suffer, and the labor force, whose unstable short- and long-term employability will impact their quality of life.

Addressing the skills gap in low-income countries requires an overhaul of the education system, including a massive investment in educational programs and infrastructure, which normally takes several years before the benefits can be realized. In addition, pursuing such sweeping reforms entails implementation, financial, technological, and political challenges that are difficult for most low-income countries to overcome in the immediate term.

One potential solution to narrow or close the skills gap would be to rely on the skills of return migrants who accumulated sufficient skills in more advanced countries, introducing new skills and competitiveness to the workforce. The prospect for tapping into the skills of return migrants is buoyed by evidence that a high percentage of those who migrate end up retuning home (John Gibson and David McKenzie, 2011), and the institutionalization by advanced countries of temporary visa programs ${ }^{16}$ that allow migrants from developing countries to take up employment for a certain period, thereby enabling them to accumulate skills meeting higher quality standards in those countries.

This research aims to examine two questions. First, how much demand exists for return migrants who accumulate skills in more developed foreign countries in skills-intensive occupations, relative to equivalent workers who accumulate the same skills in local labor market? Second, does the demand for overseas work experience differ by foreign country where skills are accumulated, and by job and employer characteristics?

\footnotetext{
${ }^{15}$ For instance, the 2010 World Economic Forum's report on talent mobility stated that the skills gap is a barrier to sustainable growth and businesses' ability to grow and innovate. Furthermore, an annual publication by UNESCO (2012) declared that the skills gap is "especially important for the world's young people aged 15-24, most of whom live in developing countries where there are few opportunities for productive employment."

${ }^{16}$ Various employment visas implemented in Singapore and the temporary guest worker program and H-1B visa program implemented in the U.S are leading examples.
} 
Examining the demand for return migrants is difficult because those who choose to migrate are fundamentally different on observable and unobservable characteristics from those who choose not to migrate in the first place, making it hard to construct an appropriate comparison group (McKenzie et al., 2010; Gibson and McKenzie, 2011; McKenzie, 2012). In the outmigration literature, there are lottery programs (e.g., US H-1B visa lottery and New Zealand visa lottery program) that enable researchers to causally estimate the return to migration ${ }^{17}$ (i.e., the impacts of people leaving their home country for other countries). In contrast, in return migration, there are no precedents for policy programs that will serve as natural experiment allowing for causal inference of return migration.

One promising, yet underexplored, way to overcome the challenge associated with selectivity in migration is to rely on resume audit methodology to ensure that migrants and nonmigrants are similar in all observable and unobservable characteristics except for one important dimension - migration experience. Then, any observed differences in employers' propensity to hire workers from the two groups can be attributed to employers' reaction to migration experience. The resume auditing method has proven quite useful for studying differences in labor outcomes by race (Bertrand and Mullainathan, 2003), age (Lahey, 2008; Neumark et al., 2015), length of unemployment (Kroft et al., 2013), college education (Martorell et al, 2014), and nationality (Oreopoulos, 2011). This method has never been applied to study migration and has been limited to understanding labor markets in the United States and Canada.

To examine how returning skilled migrants can potentially close the skills gap and strengthen the local labor market, Myanmar offers an excellent case study due to its unique economic and political history. Since its independence from Great Britain in 1948, Myanmar has been affected by perennial political unrest, including governance by three consecutive military regimes until 2011. Decades of crackdowns on students (most notably the prolonged closure of all universities in 1988 and 1996 following nationwide protests against the regimes), political oppression, and severe economic hardships triggered a departure of the skilled and talented to other countries in search of better economic opportunities. Meanwhile, the country's education system has failed to produce graduates equipped with skills that employers need (as a result of

\footnotetext{
${ }^{17}$ For instance, Clemens (2013) exploits a US H-1B visa lottery program that exogenously determines whether an Indian software worker works in India or in US and finds that an average software developer earns \$USD 55,000, more than an equivalent worker in India. Likewise, McKenzie et al. (2010), exploiting outcomes from a lottery program used to admit migrants from Tonga to New Zealand, find that migrants on average see a $263 \%$ increase in income one year after arriving in New Zealand.
} 
the absence of education reforms, significantly curtailed school duration, and the shutdown of academically prestigious universities).

Although no official statistics are available, anecdotal evidence suggests that a large number of Burmese migrants work as engineers, skilled laborers, surveyors, IT analysts, and nurses in more advanced countries (relative to Myanmar) such as Singapore and Malaysia. Many of these migrants have worked for international firms and accumulated skills consistent with global standards. Thus, they could be a potential source of skills for employers in Myanmar if programs and policies designed to attract them to return home can be put in place ${ }^{18}$. The historical context and current political climate of Myanmar provide a unique opportunity to explore how return migrants fare in the labor market, which will generate policy implications specific to Myanmar, but also applicable to other developing countries facing shortages of sufficiently skilled workers.

In this paper, I present results from a resume audit study to examine the demand for work experience accumulated in overseas labor markets relative to local labor market. To my knowledge, this is the first labor market audit study performed in a developing country, and I discuss the challenges that must be considered in this context. Hundreds of fictitious resumes were submitted online in response to job openings in skill-intensive occupations in the Yangon area of Myanmar. The resumes were randomly assigned whether an applicant accumulated work experience in overseas labor markets (Malaysia or Singapore) or in local labor market (Myanmar). The choice of Singapore and Malaysia labor markets in this application is meant to reflect the actual situation that most skilled migrants from Myanmar work in these countries. In addition to labor market experience (i.e., foreign or local), I also randomized whether an applicant is female and whether an applicant resides in a rich or poor neighborhood to uncover additional factors that explain employers' interest in an applicant.

The resumes were submitted in response to postings for skilled occupations (software developer and programmer, accountant, and engineer) by two kinds of employers (foreign and local). These skilled occupations are chosen because they represent growing occupations as Myanmar has been trying to move from an agriculture-based economy toward a service, manufacturing and production based economy. As the Myanmar economy is projected to grow at

\footnotetext{
${ }^{18}$ In fact, some skilled migrants have already returned home to take advantage of increased economic opportunities opening up in Myanmar since the country opened up in 2011. See for instance, http://www.straitstimes.com/asia/seasia/the-return-of-the-burmese-diaspora.
} 
an annual rate of approximately $8 \%$ in the coming years, according to the Asian Development Bank (ADB) and the International Monetary Fund (IMF), a shortage of workers with sufficient skills among these occupation groups will be an issue for employers in the coming years. In addition, as foreign employers' share of total employment has been growing since 2011 as a result of steady inflows of foreign direct investments, it is also crucial to examine the skills demand among foreign employers. One of the contributions of this paper is to understand the heterogeneous responses across occupations and employers.

Overall, I do not find statistically significant effects that foreign experience is favored by employers, but this aggregate effect masks occupation-specific heterogeneity by employer type (foreign or local). In addition to foreign experience, I also find differences in outcomes by gender and neighborhood. Specifically, software developers and programmers with foreign experience are highly favored by employers, particular if the experience has been gained in Singapore. The demand for Singapore experience among software developers and programmers is mainly driven by foreign employers. This finding is robust to various sample restrictions and specifications. Software developers and programmers living in a wealthy neighborhood receive as many first callbacks from employers as those having Singapore experience. The positive return to living in a wealthy neighborhood is mainly due to local employers. Among accountants and engineers, I find no systematic and significant difference in callback rates between foreign and local applicants. I also find gender gaps in callback rates among accountants and engineers: female accountants are more likely to receive callback than male accountants; in contrast, female engineers are less likely to receive callbacks than male engineers. The gender gaps among accountants and engineers are consistent with occupational trends that favor one gender over another

The rest of the paper is organized as follows. Section 2 presents the experimental design and describes the data source used in this analysis. Section 3 details empirical analysis and Section 4 presents the results. Section 5 summarizes key findings and discusses their policy implications, which are followed by a discussion on the limitations of the study and suggestions for future research. 


\section{RELATED LITERATURE}

This research contributes to a growing literature on "brain gain"19, which suggests that countries, particularly developing countries, benefit from emigration through accumulation of human capital when migrants return home. Theoretical frameworks on return migration and the incentives to return are provided in Borjas and Bratsberg (1996), Dustmann and Weiss (2007), Mayr and Peri (2009), Dustmann and Weiss (2007), and Dustmann et al. (2011). Others, including Stark et al. (1997), Maria and Lazarova (2012), Santos and Postel-Vinay (2003), have developed theoretical models to analyze the conditions under which temporary migration opportunities can increase the human capital of a source country and the prospect of a higher return to human capital induces individuals to accumulate more human capital than they would have formed in the absence of migration. Similarly, Beine et al. (2008) find that the prospect of migration induces an increase in educational investment at home and results in a higher level of human capital stock than would be the case in the absence of migration.

As suggested by the theoretical models, one incentive for individuals to return is the prospect of earning a wage premium in the home labor market, which has resulted in many empirical studies examining if return migrants receive income premiums for the skills accumulated abroad. Using data from two national surveys conducted in Ireland, Barrett and Connell (2001) and Barrett and Goggin (2010) find that returning Irish migrants earn 7 to 10 percent more than comparable stayers, and the wage premium is larger for those with advanced degrees and for those coming back from the US, Canada, New Zealand, and Australia. Likewise, Gang and Yun (2000) find that Hungarian women with overseas work experience earn a wage premium, but fail to find a wage premium for men, attributing the gender difference to the propensity of men and women to enter different industries while working overseas. Reinhold and Thom (2013) conduct an empirical analysis of the relationship between the US migration experience and earnings in the Mexican labor market, and find that each year of migration experience is associated with a $2.2 \%$ increase in earnings, with occupation-specific job experience accounting for much of this return. When restricting the sample to unskilled manufacturing workers, the authors find the return to be as high as $8.7 \%$ increase in earnings, and those with English skills and documented migration experience are also found to earn a

\footnotetext{
${ }^{19}$ Remittances sent home is also one aspect of "brain gain" that receives considerable attention in the "brain drain" literature. See Yang (2008) and Adams Jr (2011) on the economic impacts of remittances on remaining households and individuals.
} 
higher wage premium. Focusing on central European countries and using data from the harmonized European Union Labor Force Survey, Martin and Radu (2012) estimate the wage premium to return migrants to be as high as $45 \%$.

Contrary to what the theoretical models predict, Gibson and McKenzie (2011) find little evidence financial incentives play in the decision to return. In contrast, the authors find social ties and life styles to be strong determinants of return migration. In addition, the time away from home can result in a loss of social capital that can outweigh the potential gain from migration experience. For instance, Sun (2013) analyzes data from the venture capital industry in China and finds that return venture capitalists perform systematically worse than comparable nonmigrants. Specifically, the author fins that the percentage of successful exits as a result of targeting promising projects and better providing value-added services is consistently lower for return migrants, compared with non-migrants. The author attributes this difference in performance to the mismatch between the skills that return migrants accumulated overseas and the skills demanded by local employers, and most importantly the loss in social connections and ties after years of living abroad.

While many studies focus on the relationship between migration experience and earnings, studies examining employment potential of returnees are very limited ${ }^{20}$. Despite having the advantage of foreign experience, returnees could face barriers to full participation in local labor market. For instance, skills mismatch, high remuneration requirement, and lack of cultural awareness and sensitivity will make them unattractive to potential employers, and lack of social ties and connections will lengthen their search process and unemployment spell. Thus, it is important to investigate the demand for return migrants because they have to search in the local labor market and match their skills to potential employers before potential gains to migration experience can be realized. The current paper aims to fill this literature gap.

\footnotetext{
${ }^{20}$ The only study I am aware of that examined the employment status of returnees is Saarela and Finna (2009), who found that the chance of employment for returning Finns is half that of non-migrants. This employment difference is stable over time after their returns and is robust across different socioeconomic groups. However, this estimate is likely to suffer from selection bias, as the analysis simply regresses the employment status on migration status, controlling for observables.
} 


\section{EXPERIMENTAL DESIGN}

This is the first labor market audit study performed in a developing country and differs in some respects to audit studies conducted in the United States and Canada due to additional constraints and challenges that one faces with this type of research in a developing country. While prior studies have applied auditing methodology to study discrimination in the labor markets in the U.S. (e.g., Lahey, 2008; Bertrand and Mullainathan, 2004; Kroft et al., 2013), and in Canada (Oreopoulos, 2011), I find no precedent for studies applying the methodology to a setting in a developing country. This context presents problems for the audit method. Table 17 provides a comparison of various aspects of the experimental design between this audit study and prior labor market audit studies conducted in US and Canada.

Successful implementation of resume audit studies depends on a high percentage of the population having access to internet and using email as the main channel of communications. This is not the case in many countries, particularly in developing countries. According to Internet World Stats statistics ${ }^{21}$, less than 2 percent of the Myanmar population has access to internet. This study sends applications by email (consistent with the literature), though there are concerns about the types of employers that accept applications by email compared to employers that will not be in our study (those that do not accept applications by email).

The implementation of this study and analysis of the data were also altered due to some of the unique - relative to the literature - challenges faced by conducting this method in Myanmar. First, employers in Myanmar do not rely as heavily on resumes in terms of screening applicants and inferring productivity, especially compared with other countries. Rather, personal interview combined with oral examination about knowledge on relevant subjects is still the preferred methods for screening applicants. Second, the marginal cost to interview an applicant is very low. These factors result in a high percentage of applicants being interviewed for a job opening (the average callback rate found in this study is $22 \%$, which compares with $3-5 \%$ found in prior studies, Table 19), making resumes relatively less effective as a screening device and thus weakening the effects of listing any resume characteristics (e.g., foreign experience).

Moreover, in prior audit studies, information regarding whether a resume submitted receives a callback is retrieved from content of voice message left by employer. Unlike in other countries, voice mailbox service is not available in Myanmar as the telecommunication industry

\footnotetext{
${ }^{21} \mathrm{http}: / / \mathrm{www}$. internetworldstats.com/stats3.htm
} 
is still in its early development stage. Whenever an employer calls back, a trained auditor pretending to be the applicant has to answer the call and is instructed to mention to employer over the phone that he/she is no longer interested in the employment opportunity. As a result, the employer is more likely to call back the second applicant for an interview.

Given evidence that many employers are simply calling back all applicants, an audit study approach is less likely to detect discrimination in this context. My analysis focuses on outcomes which will partially circumvent this issue. These concerns suggest that the more appropriate outcomes to uncover an employer' interest in an applicant for this analysis will be (1) if a resume submitted is the first to receive a callback for an interview, and (2) if a resume submitted receives a callback for an interview conditional on an employer calling back only one applicant. The first outcome produces variation even when employers callback both applicants and some of this variation may be informative about preferences. The second outcome eliminates employers that are calling back all applicants. It does not induce selection bias since it is selecting (implicitly) on a firm fixed effect. By including both applicants in the pair in the analysis, I am not creating selection bias. Instead, I am simply focusing in on firms more likely to be making active decisions based on the resumes.

Given the constraints of working in a small developing country and the small number of new job openings available each week, achieving a large sample size comparable to that of previous audit studies conducted in US was difficult so the analysis has less power than those found in the literature, primarily resulting from characteristics of the Myanmar job market.

\section{a. Resume Construction}

Preparation of the resumes began with collecting job requirements from job advertisements and preparing resumes meeting those requirements in terms of educational attainment, years of work experience, salary requirement, and relevant computer skills. For each job posting, I prepared two resumes, and for each resume, I randomized the following four variables: (1) labor market experience (local/foreign), (2) foreign country (Singapore/Malaysia) conditional on being assigned foreign experience, (3) gender (male/female), (4) neighborhood (rich/poor).

Each resume listed the job title, period of employment, and company name of an applicant's recent three jobs in chronological order. The total years of work experience listed in the resume were always the same for both applicants and met the job requirement. Similarly, age 
of applicant, year of graduation, college major, university, computer skills, and other related skills were the same for both resumes. It is unlikely that employers in the Myanmar labor markets would suspect that these resumes were not submitted by real applicants. The resumes themselves were designed based on a large pool of actual resumes used by applicants in the Myanmar market. While each employer was sent two resumes, they were sent at least a day apart. Because the number of features randomized by the experiment was large, it was unlikely that the resumes would have similarly listed characteristics to describe the applicants. Furthermore, different fonts and layouts were used for each resume sent to an employer. The font and layout choices were also randomized. It is very likely that employers viewed each resume as an independent applicant.

If an applicant had foreign experience, this information was salient to employers in the subject line of the email sent to the employer by listing "[Position applying for]: Applicant with work experience in Singapore/Malaysia", as well as in the content of the application letter by listing "I had relevant work experience in Singapore/Malaysia". In addition, foreign experience is also salient in the resume by listing an applicant's last three foreign employers, and their foreign addresses. Gender of an applicant was conveyed through the applicant's name and mentioned in the resume. Name of an applicant was always listed at the top of the resume with a large font size. Address and contact information were listed below the name. One of the two resumes was randomly assigned an address in Bahan Township, one of the most prosperous townships in Yangon, and the other an address in North Okkalapa Township, one of the most impoverished townships in Yangon ${ }^{22}$. Each resume was randomly assigned a template and a cover letter.

Finally, resumes were saved as word files and randomly submitted via emails (independent of any resume characteristics) to the employers over a two-day period (Wednesday to Thursday) in each of the 19 weeks between March 23, 2015 and August 10, 2015.

Unsuccessful applications due to incorrect employers' email addresses, which constitute less than $1 \%$ of the sample, were dropped from the sample.

\footnotetext{
${ }^{22}$ The exact location map of the chosen rich and poor neighborhood is shown in Appendix I.
} 


\section{b. Sample and data}

The sample for job openings is from a popular magazine among job seekers in Myanmar (Opportunity; http://www.opportunity.com.mm/). The magazine carries only job advertisements, is published weekly, and accounts for approximately $90 \%$ of all job advertisements in the country. Job openings are classified by industrial sector: (1) production and manufacturing, (2) construction, (3) tourism, (4) IT, (5) trading, (6) service, and (7) Non-government organizations (NGO) and international non-government organizations (INGO). I restrict the sample to (1) skills-intensive and professional job categories, (2) job openings that require applicants to submit resumes via email, and (3) non-NGO and non-INGO jobs. The distribution of sample job openings, broken down by occupations, is provided in Appendix E. Broadly, 46\% of them can be grouped as accountant, $39 \%$ as engineer, and $14 \%$ as software developer/programmer.

The final sample consists of 1,938 resumes submitted to 969 sample job openings. I restrict the sample to one randomly selected job opening per employer although several employers list multiple job openings in a given week. Appendix F shows the distribution of the total number of job openings, sampled job openings, and resumes sent by week.

Table 18 presents results for mean equality tests of the randomly assigned resume characteristics to investigate if they are balanced between local and foreign applicants. The last column reports the p-values, with the null being that the means are equal between local and foreign applicants. The results suggest that randomization was a success. I also provide results with and without these additional controls. Given that they randomized, the inclusion of these controls should not matter and my results suggest that, in practice, they do not.

\section{EMPIRICAL ANALYSIS}

This section discusses how the outcomes and treatment variables are defined, the covariates entering the regressions, and the various specifications used for estimations.

\section{a. Dependent Variable}

I consider two outcomes in this analysis: (1) if a resume sent is the first to receive a callback for interview (this outcome is realized when either one of the two resumes submitted receives a callback, or both resumes receive a callback), (2) if a resume receives a callback 
conditional on job openings in which only one applicant receives callback. I define a callback as a message from an employer asking an applicant over the phone to set up an interview.

The outcome used in prior resume audit studies (i.e., Bertrand and Mullainathan, 2004; Kroft et al., 2013; Lahey, 2008; Oreopoulos, 2011) is if a resume submitted receives a callback for interview. I study an additional outcome because of the additional information it provides in this context. This study finds that a majority of employers call back at least one applicant and, as can be seen from Table 19, the average callback rate is $22 \%$, compared to $3-5 \%$ in prior studies. Sample statistics from Table 19 reveal that of 969 sample job openings, $72 \%$ result in no callbacks, $13 \%$ in a callback to one of the two applicants, and $15 \%$ in callbacks to both applicants.

\section{b. Independent Variables}

Table 20 reports descriptive statistics of the independent variables. As for treatment assignment, of 1,938 resumes submitted, half are associated with foreign work experience. Conditional on being assigned foreign experience, $50 \%$ of resumes are associated with foreign work experience accumulated in Malaysia, while the remaining 50\% in Singapore.

Each of the four resume templates is equally represented in the sample. About $52 \%$ of resumes are female, and 50\% are associated with the rich neighborhood. The average age of applicants is approximately 27 years, and half of sample resumes are assigned cover letter \# 1 .

\section{c. Empirical Models}

To examine if employers prefer foreign work experience, I will estimate the following specification.

$$
Y_{i j t}=\beta_{0}+\beta_{1}^{*} \text { foreign }_{i j t}+\omega X_{i j t}+\gamma_{t}+\varepsilon_{i j t}
$$

The list of variables entering the regressions and their detailed explanations are provided in Appendix G. For each specification and sample restriction, I will report the results with and without controls. OLS regression will produce unbiased estimates of the foreign experience effects, as long as any omitted variables are uncorrelated with the foreign experience dummy variable. The primary estimates should be robust to the inclusion of controls if there are no systemic differences in controls between foreign and local applicants other than foreign experience. The controls include resume characteristics $X_{i j t}$ (for resume $i$ submitted to job $j$ in 
week $t$ ) and a set of dummies $\left(\gamma_{t}\right)$ representing the week $t$ where resumes were submitted. Including controls will help reduce unexplained error, thereby improving the statistical precision of the primary estimates.

To further investigate if return to foreign experience widens with foreign country where experience was accumulated, I will introduce dummies for Malaysia and Singapore separately. Likewise, to assess if returns are different by employer characteristics (foreign/local companies), or by academic discipline (accounting/software development/engineering), or by seniority (entry/non-entry), or a combination of these, I will restrict the sample according to subpopulation of interest. All standard errors are adjusted for clustering at employer level (Bertrand and Mullainathan, 2004; Oreopoulos, 2011).

\section{EXPERIMENTAL RESULTS}

One of the contributions of this paper is to understand the heterogeneous responses. As such, I will present the results by subsamples as the following.

\section{a. Main results (Outcome: first callback)}

Table 21 presents the main results. The results in Column (1) suggest that there is no difference in employer responses between resumes listing foreign and local experience. This estimate is unaffected by the inclusion of additional controls (Column (2)). In Columns (3) and (4), I present the same results for local employers only. Again, I do not find statistically significant differences by migration status. When selecting on foreign employers (Columns (5) and (6)), the results are similar.

Table 22 presents results where I disaggregate the effect by Singapore and Malaysia experience (the reference group is local experience). The point estimates imply that the Singapore experience is favored by foreign employers and less favored by local employers, whereas Malaysia experience is less favored by both local and foreign employers. However, these coefficients are not statistically significant.

\section{b. By occupation (Outcome: first callback)}

Next, I investigate heterogeneity across three occupation groups - (1) software developer/programmer, (2) accountant, and (3) engineer. It may be helpful to explain first why 
we might expect heterogeneous effect by occupation. The main educational institutions that produce software developers and programmers are the Yangon University of Computer Studies and Mandalay University of Computer Studies. Degree programs on computer studies were introduced relatively late in Myanmar, compared to other countries. Founded in 1971, The Yangon University of Computer Studies (http://www.ucsy.edu.mm/ucsy/) was the only higher educational institution granting degrees in computer studies until 1997, when a second University of Computer Studies was opened in the city of Mandalay (http://www.ucsm.edu.mm/). Absence of education reforms, prolonged closure of the institutions, significantly curtailed school duration, and insufficient resources were major factors affecting the skills level of graduates of these institutions. Further, the development of the software industry in Myanmar was hampered by decades of isolation that restricted inflows of IT technologies, personnel, and tech firms from more developed foreign countries. Since the country opened up in 2011 for the first time since its independence, there has been an increase in the demand for skilled IT and software personnel, and this increased demand is mainly fueled by a boom in the service industry led by the tourism, hospitality, retail, and financial sector. Unlike education in IT, knowledge about accountancy is well established within local institutions and companies. Furthermore, practice of accountancy tends to be country specific. For instance, practitioners are required to be locally certified by professional and statutory boards governing accountancy practices and licenses that are subject to annual renewal ${ }^{23}$; another example is that company annual financial reports are required to be prepared and approved by locally certified accountants, according to prevailing Myanmar accounting rules. Compared to the two Universities of Computer Studies, institutions granting engineering degrees were relatively old, dating back to British colonial period ${ }^{24}$. As a result, knowledge about engineering is more developed than computer science in the Myanmar higher education system.

While selecting on occupations is potentially informative about heterogeneity in the effect of foreign experience, the number of available jobs for applicants in a specific occupation

\footnotetext{
${ }^{23}$ The Myanmar Institute of Certified Public Accountants (http://myanmar-icpa.org/) and the Myanmar Accountancy Council (http://www.aseanaccountants.org/memberpage-7-

Myanmar\%20Accountancy\%20Council\%20(MAC)\%20Union\%20of\%20Myanmar.html) are the two governing bodies of accountancy.

${ }^{24}$ For instance, the Yangon Institute of Technology is the premier engineering university of Myanmar, which was established as Department of Engineering under Rangoon University in 1924.
} 
is substantially reduced. Consequently, sample sizes can become small, reducing power to detect small effects.

Table 23 reports results for software developer / programmer occupation group. The results in Column (1) indicate that resumes listing foreign experience are on average 18.9 percentage points more likely to receive callbacks first from employers than local applicants and the difference is significant at the $1 \%$ level. Based on this point estimate, applicants with foreign experience are 116 percent more likely to receive callbacks first than applicants with local experience (baseline estimate is 16.2 percentage points, Table 23 Column (1)). The point estimate from listing foreign experience is robust to the inclusion of controls (Column (2)). It is useful to compare the estimated effects of listing foreign experience to those of other resume characteristics found in prior resume audit studies. Bertrand and Mullainathan (2004) find that resumes with White sounding names are 50 percent more likely to receive callbacks than resumes with African American sounding names. Oreopoulos (2011) finds that English sounding names are 39 percent more likely to receive callbacks from employers than Chinese, Indian, or Pakistani names. Lahey (2008) finds that younger workers are 40 percent more likely to receive callbacks than older workers. Kroft et al. (2013) find that resumes listing an eight month unemployment spell are 45 percent less likely to recevel callbacks than resumes listing a one month of unemployment spell. The returns to foreign experience in Myanmar for software jobs are large relative to estimates found in the literature.

When selecting on local and foreign employers, the results suggest that the positive return to foreign experience is mainly attributed to foreign employers (Table 23 Column (3) \& (5)) ${ }^{25}$.

Table 24 presents the results where I disaggregate the effect by Singapore and Malaysia experience among software jobs. With a population of approximately 5.5 million people ${ }^{26}$ and skilled migrants constituting over one-third of its labor force ${ }^{27}$, Singapore is more economically developed than Malaysia, and both countries are more developed than Myanmar in many aspects. Home to leading multinational corporations such as IBM, Singapore's software industry is considered the most developed among South East Asian nations and the skills level of its labor force are relatively high compared with other South East Asian nations.

\footnotetext{
${ }^{25}$ For sensitivity analysis, since I submitted two resumes to each job opening, I can also analyze the pattern of callbacks among job openings in which at least one of the two applicants receives callback. The results (not shown here) reveal that the patterns of callbacks are similar to those reported in Table 23.

${ }^{26} \mathrm{http} / / / \mathrm{www} \cdot$ singstat.gov.sg/statistics/browse-by-theme/population-and-population-structure

${ }^{27}$ http://stats.mom.gov.sg/Pages/Labour-Force-Summary-Table.aspx
} 
With this in mind, applicants for software developer job openings with Singapore experience are more preferred than applicants with a Malaysia experience (Table 24 Column (1)). Specifically, the point estimates from listing Singapore and Malaysia experience are 24.8 and 12.4 percentage points higher than the estimated effects of listing local experience, respectively. The results are robust to the inclusion of additional controls (Column (2)). When restricting the sample to foreign employers, the gap in first callback rate between Singapore and local applicants widens: when deciding who to callback first, foreign employers are 42.9 percentage points more likely to callback Singapore applicants first, relative to local applicants, and the difference is significant at the $5 \%$ level (Column (5)) ${ }^{28}$.

Next I examine if there is any return to listing overseas work experience among accountants, who make up $46 \%$ of the sample job openings. Most accounting jobs require at least a degree, knowledge of accounting software, local accounting experience, internationally recognized qualifications such as London Chamber of Commerce \& Industry (LCCI), or professional license such as Certificate in Public Accounting (CPA). Local companies' share of accounting jobs is about $82 \%$. Table 25 presents the results for accountants, separated by employer and by seniority. There does not appear to be a significant difference in first callback rates between resumes listing foreign experience and local experience among accountants. As previously mentioned, the possible explanation for a lack of or negative return to foreign experience is that accounting practices tend to be country specific, requiring practitioners to be certified by a local professional and statutory board governing accounting practices and licenses and companies to have their financial reports prepared and approved by locally certified accountants.

Engineers are the second largest occupation group, making up 38\% of the sample job openings. Table 26 presents the results for engineers. Overall, resumes listing foreign experience are as likely to receive first callbacks as resumes listing local experience. When the sample is separated by local and foreign employers, there is no significant difference in callback rates between local and foreign applicants either, although the average callback rate for Singapore experience is slightly higher among foreign employers but its coefficient is not significant.

Civil engineers make up $40 \%$ of all engineering jobs, and their overall sample share is

\footnotetext{
${ }^{28}$ I reach the same conclusions if I restrict the sample to job openings in which at least one of the two applicants receives callback.
} 
approximately $16 \%$. When selecting on civil engineers, the results reveal that the point estimates from listing Malaysia and Singapore experience are not statistically significant for civil engineers, which is true for both local and foreign employers (Table 27).

\section{c. By occupation (Outcome: only one applicant receives callback)}

Another way to analyze whether listing foreign experience generates employers' interest in an applicant is to focus on jobs in which only one applicant (out of two) receives callback for an interview. When selecting on job openings in which only one of the two applicants receives a callback, the estimated effect of foreign experience becomes larger and the differences in callback rates between foreign and local applicants become statistically significant across all occupations. Since this sample restriction results in a substantial decrease in the sample size, I group Malaysia and Singapore experience into foreign experience group to enhance the statistical power. Table 28 reports the results by occupation. As before, software developers and programmers with foreign experiences are 62 percentage points more likely to receive a callback for an interview and the difference is significant at the 1\% level (Column (1)). Similarly, engineers with overseas work experience are 23 percentage points more likely to receive a callback (Column (3)) and civil engineers with foreign experience are 27 percentage points more likely to receive a callback, but its coefficient is not significant possibly due to a small sample size (Column (4)). As for accountants, the estimated effect of listing foreign experience qualitatively agrees with the findings reported in Table 25: when deciding to callback only one applicant, employers are 18.2 percentage points less likely to callback accountants with foreign experience for an interview, and the coefficient is statistically significant (Column (2)).

\section{d. By neighborhood (Outcome: first callback)}

In addition to labor market experience, I also randomized whether an applicant lives in a rich or impoverished neighborhood. Results in Table 23 indicate that zip code information is a strong determinant of an employer's interest in a software developer/programmer. Among software jobs, resumes associated with rich neighborhood are on average $23 \%$ percentage points more likely to receive callbacks first from employers than resumes associated with poor neighborhood and the coefficient is significant at the $1 \%$ level (Column (2)). Interestingly, the estimated effect of listing a rich neighborhood is larger than that of listing foreign experience. A separation of the sample between local and foreign employers shows that the zip code 
information is the strongest independent determinant among local employers (Column (4)). The estimated effect of rich neighborhood is unaffected by the introduction of Singapore and Malaysia dummies (Table 24 Column (2)). Interestingly, the positive return to listing rich neighborhood is comparable to that of Singapore experience. In contrast to software jobs, there are no significant differences in callbacks by neighborhood characteristics among accountants and engineers (Table 25 and Table 26).

\section{e. By gender (Outcome: first callback)}

Among accountants, resumes associated with female names generate more interest among employers than male names and its estimated sign is consistently positive across the four subsamples in Table 25. Overall, female accountants are 88 percent more likely to receive callback first ( $15 \%$ callback rate for females and $8 \%$ callback rate for males). This finding is consistent with the occupational trend in which a large percentage of accountants are females. In contrast, male engineers are more favored by employers: the average first callback rate for resumes associated with male names is 38 percent higher than female names among engineering jobs ( $15 \%$ for male names and $11 \%$ for female names). This gender gap widens when selecting on civil engineers. On average, male civil engineers are 100 percent more likely to receive callback first than female civil engineers (14\% first callback rate for males and $7 \%$ for females). As one would expect, this large gender gap among engineers could solely be attributed to the physically demanding working conditions prevailing in construction sites, particularly in developing countries.

The estimated gender effect becomes larger when restricting the sample to jobs in which only one applicant receives callback for an interview (Table 28). Results in Column (2) suggest that, when deciding to callback only one applicant, employers are 29 percentage points more likely to callback female accountants and the difference is significant at the $5 \%$ level. In contrast, employers are 14 and 42 percentage points less likely to callback female engineers and female civil engineers (Column (3) and (4)).

\section{CONCLUSION}

Myanmar migrants have been returning home to take advantage of increased economic opportunities since the country opened up in 2011. With Myanmar facing a chronic shortage of 
sufficiently skilled workers, successfully integrating return migrants into the labor market and tapping into their skills is crucial to strengthening the Myanmar labor market. In this paper, I report findings from a resume-based field experiment conducted in Yangon, which examines the demand for foreign work experience accumulated in two foreign labor markets where a majority of Myanmar migrants work.

Although I do not find evidence that foreign experience increases the first callback likelihood, I find significant evidence of heterogeneity by occupation, gender, and neighborhood.

My results reveal that the average first callback rate for software developers and programmers with foreign experience is 35 percent, compared with 16 percent for those with local experience. Singapore experience is more favored, compared with Malaysia experience. Specifically, the return to Singapore experience is approximately twice that of Malaysia experience. The demand for Singapore experience among software developers is mainly due to foreign employers. When selecting on job openings in which only one of the two applicants receives a callback, the gap in callback rates between foreign and local applicants widens and the difference is highly significant despite the fact that this sample restriction has resulted in a significant decrease in the sample size I can work with. When deciding to callback only one applicant, employers are 62 percent points more likely to callback software developers and programmers with foreign experience.

Among accountants and engineers, I find no systematic and significant difference in callback rates between foreign and local applicants, and this is true for local and foreign employers. However, when selecting on accounting and engineering jobs in which only one of the two applicants receives a callback, I find significant difference in callbacks between foreign and local experience. Specifically, when deciding to callback only one applicant out of two, employers are (1) 18 percentage points less likely to callback accountants with foreign experience, and (2) 23 percentage points more likely to callback engineers with foreign experience.

My experimental design also allows me to estimate the difference in callback by neighborhood since I also randomized whether an applicant lives in a rich or impoverished neighborhood. My results indicate that zip code information is a strong determinant of an employer's interest in a software developer/programmer. Specifically, software developers and programmers living in a rich neighborhood receive as many first callbacks from employers as 
those having Singapore experience. And the zip code information is the strongest determinant among local employers. In contrast, I do not find any significant differences in callback rates by neighborhood characteristics among accounting and engineering jobs.

In addition to labor market experience and neighborhood, I can also estimate the effect of listing different gender. Overall, female accountants are 88 percent more likely to receive callback first ( $15 \%$ callback rate for females and $8 \%$ callback rate for males). In contrast, male engineers are more favored by employers: the average first callback rate for resumes associated with male names is 38 percent higher than female names among engineering jobs ( $15 \%$ for male names and $11 \%$ for female names). When deciding to callback only one applicant, employers are 29 percentage points more likely to callback female accountants, and are 14 and 42 percentage points less likely to callback female engineers and female civil engineers, respectively.

One direct policy implication that arises from findings from this research is that return migration policies each targeting specific occupation and employer will be more effective than a single policy targeting all occupations and employers. 
Table 17: Comparison of experimental design across resume-based audit studies

\begin{tabular}{|c|c|c|c|c|c|}
\hline & This research & $\begin{array}{l}\text { Bertrand, Marianne and } \\
\text { Sendhil Mullainathan. } \\
\text { 2004. "Are Emily and Greg } \\
\text { More Employable Than } \\
\text { Lakisha and Jamal:A Field } \\
\text { Experiment on Labor } \\
\text { Market Discrimination." } \\
\text { American Economic } \\
\text { Review, 94(991), 1013. }\end{array}$ & $\begin{array}{l}\text { Kroft, Kory; Fabian } \\
\text { Lange and Matthew J. } \\
\text { Notowidigdo. } 2013 . \\
\text { "Duration Dependence and } \\
\text { Labor Market Conditions: } \\
\text { Evidence from a Field } \\
\text { Experiment." The } \\
\text { Quarterly Journal of } \\
\text { Economics. }\end{array}$ & $\begin{array}{l}\text { Oreopoulos, Philip. } 2011 . \\
\text { "Why Do Skilled } \\
\text { Immigrants Struggle in the } \\
\text { Labor Market? A Field } \\
\text { Experiment with Thirteen } \\
\text { Thousand Resumes." } \\
\text { American Economic } \\
\text { Journal: Economic Policy, } \\
\text { 3(4), 148-71 }\end{array}$ & $\begin{array}{l}\text { Lahey, Joanna N. } 2008 . \\
\text { "Age, Women, and Hiring } \\
\text { an Experimental Study." } \\
\text { Journal of Human } \\
\text { Resources, 43(1), 30-56. }\end{array}$ \\
\hline Outcome(s) considered & $\begin{array}{l}\text { 1.A given resume elicits } \\
\text { the first callback for an } \\
\text { interview } \\
\text { 2. A given resume receives } \\
\text { a callback for an interview }\end{array}$ & $\begin{array}{l}\text { A given resume elicits a } \\
\text { callback or e-mail back for } \\
\text { an interview }\end{array}$ & $\begin{array}{l}\text { A given resume elicits a } \\
\text { callback or e-mail back for } \\
\text { an interview }\end{array}$ & $\begin{array}{l}\text { A resume receives a } \\
\text { callback for an interview }\end{array}$ & $\begin{array}{l}\text { A given resume elicits a } \\
\text { callback or e-mail back for } \\
\text { an interview }\end{array}$ \\
\hline $\begin{array}{l}\text { Number of resumes sent } \\
\text { for each job opening }\end{array}$ & 2 resumes & 4 resumes & 4 resumes & 4 resumes & 2 resumes \\
\hline $\begin{array}{l}\text { Resumes sent per week } \\
\text { (assuming } 4 \text { weeks per } \\
\text { month) }\end{array}$ & 100 & 135 & 250 & 200 & 78 \\
\hline Total resumes sent & 1,938 & 4,870 & 12,000 & 12,910 & 3,773 \\
\hline Duration of experiment & 4 months & 9 months & 12 months & 16 months & 12 months \\
\hline Geographical coverage & Yangon & Chicago and Boston & $\begin{array}{l}100 \text { largest metropolitan } \\
\text { areas in US }\end{array}$ & Toronto and Montreal & Boston and St. Petersburg \\
\hline Job categories sampled & $\begin{array}{l}\text { Technical, engineering, and } \\
\text { professional }\end{array}$ & $\begin{array}{l}\text { Sales, administrative, } \\
\text { clerical }\end{array}$ & $\begin{array}{l}\text { Administrative/clerical, } \\
\text { customer service, and sales }\end{array}$ & $\begin{array}{l}20 \text { different occupation } \\
\text { categories (not mentioned) }\end{array}$ & $\begin{array}{l}\text { Sales, administrative, } \\
\text { clerical }\end{array}$ \\
\hline Level of experience & All level & All level & All level & All level & $\begin{array}{l}\text { Entry-level or close-to- } \\
\text { entry-level }\end{array}$ \\
\hline Sources of sample & Opportunity magazine & $\begin{array}{l}\text { The Boston Globe and The } \\
\text { Chicago Tribune }\end{array}$ & Online job board & Online job board & $\begin{array}{l}\text { The Boston Globe and St. } \\
\text { Petersburg Times }\end{array}$ \\
\hline $\begin{array}{l}\text { Average callback rate } \\
\text { (overall) }\end{array}$ & Approximately $22 \%$ & Approximately $8 \%$ & Approximately 5\% & Approximately $10 \%$ & Approximately 5\% \\
\hline Treatment effects & $\begin{array}{l}\text { Vary by occupation, } \\
\text { employer, and outcome } \\
\text { considered }\end{array}$ & $\begin{array}{l}50 \% \text { difference in callbacks } \\
\text { between white and black } \\
\text { sounding names }\end{array}$ & $\begin{array}{l}45 \% \text { difference in callbacks } \\
\text { between workers with short } \\
\text { unemployment spell and } \\
\text { workers with long } \\
\text { unemployment spell }\end{array}$ & $\begin{array}{l}\text { 39\% difference in callback } \\
\text { between English sounding } \\
\text { names and Indian, } \\
\text { Pakistan, Chinese sounding } \\
\text { names }\end{array}$ & $\begin{array}{l}44 \% \text { difference in callbacks } \\
\text { between young and old } \\
\text { workers }\end{array}$ \\
\hline
\end{tabular}


Table 18: Randomization Tests

\begin{tabular}{lccr} 
& \multicolumn{2}{c}{ Sample Means } & \\
\cline { 2 - 3 } & $\begin{array}{c}\text { Local } \\
\text { Applicants }\end{array}$ & $\begin{array}{c}\text { Foreign } \\
\text { Applicants }\end{array}$ & $\begin{array}{c}\text { p-value of test } \\
\text { of mean } \\
\text { equality }\end{array}$ \\
\hline Resumes associated with template 1a & 0.25 & 0.25 & 0.87 \\
Resumes associated with template 1b & 0.27 & 0.24 & 0.09 \\
Resumes associated with template 2a & 0.24 & 0.27 & 0.09 \\
Resumes associated with template 2b & 0.25 & 0.25 & 0.87 \\
Female applicants & 0.52 & 0.52 & 0.93 \\
Resumes associated with rich neighborhood & 0.52 & 0.48 & 0.16 \\
Resumes associated with cover letter \#1 & 0.50 & 0.50 & 0.96 \\
\hline \hline
\end{tabular}

Table 19: Descriptive Statistics for Callbacks

\begin{tabular}{lllll}
\hline \hline & $\mathrm{N}$ & Mean & Min & Max \\
\hline Resume is the first to receive a callback for interview & 1,938 & 0.14 & 0 & 1 \\
Resume receives a callback for interview & 1,938 & 0.22 & 0 & 1 \\
Job openings in which no applicants receive callbacks & 969 & 0.72 & 0 & 1 \\
Job openings in which only one applicant receives callback & 969 & 0.13 & 0 & 1 \\
Job openings in which both applicants receive callbacks & 969 & 0.15 & 0 & 1 \\
\hline \hline
\end{tabular}

Table 20: Descriptive Statistics of Independent Variables

\begin{tabular}{lcccc}
\hline \hline & $\mathrm{N}$ & Mean & Min & Max \\
\hline Treatment Variables & & & & \\
Foreign experience & 1,938 & 0.50 & 0 & 1 \\
Malaysia Experience $\mid$ Foreign Experience & 969 & 0.50 & 0 & 1 \\
$\quad \begin{array}{l}\text { Singapore Experience } \mid \text { Foreign Experience } \\
\text { Covariates }\end{array}$ & 969 & 0.50 & 0 & 1 \\
CV template 1a & 1,938 & 0.25 & 0 & 1 \\
CV template 1b & 1,938 & 0.25 & 0 & 1 \\
CV template 2a & 1,938 & 0.25 & 0 & 1 \\
CV template 2b & 1,938 & 0.25 & 0 & 1 \\
Resumes with female names & 1,938 & 0.52 & 0 & 1 \\
Resumes associated with rich neighborhood & 1,938 & 0.50 & 0 & 1 \\
Age of applicant & 1,938 & 26.57 & 24 & 37 \\
Cover letter \# 1 & 1,938 & 0.50 & 0 & 1 \\
\hline \hline
\end{tabular}


Table 21: Dependent variable: if a resume is the first to receive a callback for an interview

\begin{tabular}{|c|c|c|c|c|c|c|}
\hline \multirow[t]{2}{*}{ Employer } & \multicolumn{2}{|c|}{ Local and foreign companies } & \multicolumn{2}{|c|}{ Local companies } & \multicolumn{2}{|c|}{ Foreign companies } \\
\hline & (1) & (2) & (3) & (4) & $(5)$ & $(6)$ \\
\hline Foreign experience & $\begin{array}{l}-0.008 \\
(0.016)\end{array}$ & $\begin{array}{l}-0.008 \\
(0.016)\end{array}$ & $\begin{array}{l}-0.014 \\
(0.017)\end{array}$ & $\begin{array}{l}-0.015 \\
(0.017)\end{array}$ & $\begin{array}{c}0.015 \\
(0.038)\end{array}$ & $\begin{array}{c}0.008 \\
(0.039)\end{array}$ \\
\hline Female & & $\begin{array}{c}0.002 \\
(0.016)\end{array}$ & & $\begin{array}{c}0.004 \\
(0.017)\end{array}$ & & $\begin{array}{c}0.008 \\
(0.039)\end{array}$ \\
\hline Rich neighborhood & & $\begin{array}{l}-0.004 \\
(0.016)\end{array}$ & & $\begin{array}{l}-0.015 \\
(0.017)\end{array}$ & & $\begin{array}{c}0.030 \\
(0.039)\end{array}$ \\
\hline Constant & $\begin{array}{c}0.146 \\
(0.011)^{* * *}\end{array}$ & $\begin{array}{c}0.180 \\
(0.039)^{* * *}\end{array}$ & $\begin{array}{c}0.140 \\
(0.012)^{* * *}\end{array}$ & $\begin{array}{c}0.156 \\
(0.041)^{* * *}\end{array}$ & $\begin{array}{c}0.165 \\
(0.027)^{* * *}\end{array}$ & $\begin{array}{c}0.317 \\
(0.110)^{* * *}\end{array}$ \\
\hline Additional controls & & & & & & \\
\hline Resume template fixed effects & & $\mathrm{X}$ & & $X$ & & $\mathrm{X}$ \\
\hline Week fixed effect & & $X$ & & $X$ & & $X$ \\
\hline Application letter fixed effects & & $\mathrm{X}$ & & $\mathrm{X}$ & & $\mathrm{X}$ \\
\hline $\mathrm{N}$ & 1938 & 1938 & 1538 & 1538 & 400 & 400 \\
\hline $\mathrm{R}^{2}$ & 0.000 & 0.019 & 0.000 & 0.024 & 0.000 & 0.039 \\
\hline
\end{tabular}


Table 22: Dependent variable: if a resume is the first to receive a callback for an interview

\begin{tabular}{|c|c|c|c|c|c|c|}
\hline \multirow[t]{2}{*}{ Employer } & \multicolumn{2}{|c|}{$\begin{array}{c}\text { Local and foreign } \\
\text { companies }\end{array}$} & \multicolumn{2}{|c|}{ Local companies } & \multicolumn{2}{|c|}{ Foreign companies } \\
\hline & (1) & $(2)$ & (3) & (4) & $(5)$ & $(6)$ \\
\hline Malaysia & $\begin{array}{l}-0.017 \\
(0.019)\end{array}$ & $\begin{array}{l}-0.020 \\
(0.019)\end{array}$ & $\begin{array}{l}-0.014 \\
(0.021)\end{array}$ & $\begin{array}{l}-0.018 \\
(0.021)\end{array}$ & $\begin{array}{l}-0.025 \\
(0.047)\end{array}$ & $\begin{array}{c}-0.039 \\
(0.049)\end{array}$ \\
\hline Singapore & $\begin{array}{c}0.000 \\
(0.019)\end{array}$ & $\begin{array}{c}0.003 \\
(0.019)\end{array}$ & $\begin{array}{l}-0.014 \\
(0.021)\end{array}$ & $\begin{array}{l}-0.011 \\
(0.021)\end{array}$ & $\begin{array}{c}0.050 \\
(0.045)\end{array}$ & $\begin{array}{c}0.047 \\
(0.046)\end{array}$ \\
\hline Female & & $\begin{array}{c}0.001 \\
(0.016)\end{array}$ & & $\begin{array}{c}0.003 \\
(0.017)\end{array}$ & & $\begin{array}{c}0.006 \\
(0.039)\end{array}$ \\
\hline Rich neighborhood & & $\begin{array}{l}-0.005 \\
(0.016)\end{array}$ & & $\begin{array}{l}-0.015 \\
(0.017)\end{array}$ & & $\begin{array}{c}0.031 \\
(0.039)\end{array}$ \\
\hline Constant & $\begin{array}{c}0.146 \\
(0.011)^{* * *}\end{array}$ & $\begin{array}{c}0.181 \\
(0.039)^{* * *}\end{array}$ & $\begin{array}{c}0.140 \\
(0.012)^{* * *}\end{array}$ & $\begin{array}{c}0.157 \\
(0.041)^{* * *}\end{array}$ & $\begin{array}{c}0.165 \\
(0.027)^{* * *}\end{array}$ & $\begin{array}{c}0.319 \\
(0.110)^{* * *}\end{array}$ \\
\hline Additional controls & & & & & & \\
\hline Resume template fixed effects & & $\mathrm{X}$ & & $\mathrm{X}$ & & $\mathrm{X}$ \\
\hline Week fixed effect & & $\mathrm{X}$ & & $\mathrm{X}$ & & $\mathrm{X}$ \\
\hline Application letter fixed effects & & $X$ & & $X$ & & $X$ \\
\hline $\mathrm{N}$ & 1938 & 1938 & 1538 & 1538 & 400 & 400 \\
\hline $\mathrm{R}^{2}$ & 0.000 & 0.020 & 0.000 & 0.024 & 0.005 & 0.045 \\
\hline
\end{tabular}


Table 23: Dependent variable: if a resume is the first to receive a callback for an interview

\begin{tabular}{|c|c|c|c|c|c|c|}
\hline \multirow{3}{*}{$\begin{array}{l}\text { Job category } \\
\text { Employer }\end{array}$} & \multicolumn{6}{|c|}{ Software developer / programmer } \\
\hline & \multicolumn{2}{|c|}{ Local and foreign companies } & \multicolumn{2}{|c|}{ Local companies } & \multicolumn{2}{|c|}{ Foreign companies } \\
\hline & (1) & (2) & (3) & (4) & (5) & (6) \\
\hline Foreign experience & $\begin{array}{c}0.189 \\
(0.071)^{* * *}\end{array}$ & $\begin{array}{c}0.190 \\
(0.075)^{* *}\end{array}$ & $\begin{array}{c}0.132 \\
(0.077)^{*}\end{array}$ & $\begin{array}{c}0.127 \\
(0.088)\end{array}$ & $\begin{array}{c}0.333 \\
(0.146)^{* *}\end{array}$ & $\begin{array}{c}0.233 \\
(0.167)\end{array}$ \\
\hline Female & & $\begin{array}{c}0.079 \\
(0.073)\end{array}$ & & $\begin{array}{c}0.062 \\
(0.085)\end{array}$ & & $\begin{array}{c}0.164 \\
(0.178)\end{array}$ \\
\hline Rich neighborhood & & $\begin{array}{c}0.229 \\
(0.075)^{* * *}\end{array}$ & & $\begin{array}{c}0.177 \\
(0.087)^{* *}\end{array}$ & & $\begin{array}{c}0.188 \\
(0.183)\end{array}$ \\
\hline Constant & $\begin{array}{c}0.162 \\
(0.050)^{* * *}\end{array}$ & $\begin{array}{c}0.104 \\
(0.172)\end{array}$ & $\begin{array}{c}0.132 \\
(0.055)^{* *}\end{array}$ & $\begin{array}{c}0.103 \\
(0.167)\end{array}$ & $\begin{array}{c}0.238 \\
(0.103)^{* *}\end{array}$ & $\begin{array}{c}0.473 \\
(0.429)\end{array}$ \\
\hline \multicolumn{7}{|l|}{ Additional controls } \\
\hline Resume template fixed effects & & $X$ & & $\mathrm{X}$ & & $\mathrm{X}$ \\
\hline Week fixed effect & & $\mathrm{X}$ & & $\mathrm{X}$ & & $\mathrm{X}$ \\
\hline Application letter fixed effects & & $X$ & & $\mathrm{X}$ & & $X$ \\
\hline $\mathrm{N}$ & 148 & 148 & 106 & 106 & 42 & 42 \\
\hline $\mathrm{R}^{2}$ & 0.047 & 0.174 & 0.027 & 0.145 & 0.115 & 0.445 \\
\hline
\end{tabular}

Note: The results are robust to alternative specifications of fixed effects panel estimations. Standard errors (clustered at company level) are in parentheses. $*$ $\mathrm{p}<0.10 ; * * \mathrm{p}<0.05 ; * * * \mathrm{p}<0.01$. 
Table 24: Dependent variable: if a resume is the first to receive a callback for an interview

\begin{tabular}{|c|c|c|c|c|c|c|}
\hline \multirow{3}{*}{$\begin{array}{l}\text { Job category } \\
\text { Employer }\end{array}$} & \multicolumn{6}{|c|}{ Software developer / programmer } \\
\hline & \multicolumn{2}{|c|}{ Local and foreign companies } & \multicolumn{2}{|c|}{ Local companies } & \multicolumn{2}{|c|}{ Foreign companies } \\
\hline & (1) & $(2)$ & (3) & (4) & $(5)$ & $(6)$ \\
\hline Malaysia & $\begin{array}{c}0.124 \\
(0.088)\end{array}$ & $\begin{array}{c}0.123 \\
(0.093)\end{array}$ & $\begin{array}{c}0.099 \\
(0.095)\end{array}$ & $\begin{array}{c}0.109 \\
(0.107)\end{array}$ & $\begin{array}{c}0.206 \\
(0.188)\end{array}$ & $\begin{array}{c}0.036 \\
(0.228)\end{array}$ \\
\hline Singapore & $\begin{array}{c}0.248 \\
(0.085)^{* * *}\end{array}$ & $\begin{array}{c}0.255 \\
(0.092)^{* * *}\end{array}$ & $\begin{array}{c}0.164 \\
(0.094)^{*}\end{array}$ & $\begin{array}{c}0.145 \\
(0.109)\end{array}$ & $\begin{array}{c}0.429 \\
(0.171)^{* *}\end{array}$ & $\begin{array}{c}0.392 \\
(0.208)^{*}\end{array}$ \\
\hline Female & & $\begin{array}{c}0.085 \\
(0.073)\end{array}$ & & $\begin{array}{c}0.062 \\
(0.086)\end{array}$ & & $\begin{array}{c}0.199 \\
(0.178)\end{array}$ \\
\hline Rich neighborhood & & $\begin{array}{c}0.220 \\
(0.075)^{* * *}\end{array}$ & & $\begin{array}{c}0.175 \\
(0.088)^{*}\end{array}$ & & $\begin{array}{c}0.169 \\
(0.181)\end{array}$ \\
\hline Constant & $\begin{array}{c}0.162 \\
(0.050)^{* * *}\end{array}$ & $\begin{array}{c}0.143 \\
(0.175)\end{array}$ & $\begin{array}{c}0.132 \\
(0.055)^{* *}\end{array}$ & $\begin{array}{c}0.114 \\
(0.172)\end{array}$ & $\begin{array}{c}0.238 \\
(0.103)^{* *}\end{array}$ & $\begin{array}{c}0.399 \\
(0.427)\end{array}$ \\
\hline Additional controls & & & & & & \\
\hline Resume template fixed effects & & $\mathrm{X}$ & & $\mathrm{X}$ & & $\mathrm{X}$ \\
\hline Week fixed effect & & $X$ & & $\mathrm{X}$ & & $X$ \\
\hline Application letter fixed effects & & $\mathrm{X}$ & & $\mathrm{X}$ & & $\mathrm{X}$ \\
\hline $\mathrm{N}$ & 148 & 148 & 106 & 106 & 42 & 42 \\
\hline $\mathrm{R}^{2}$ & 0.057 & 0.184 & 0.031 & 0.146 & 0.140 & 0.484 \\
\hline
\end{tabular}


Table 25: Dependent variable: if a resume is the first to receive a callback for an interview

\begin{tabular}{|c|c|c|c|c|}
\hline \multirow{3}{*}{$\begin{array}{l}\text { Employer } \\
\text { Job category }\end{array}$} & \multicolumn{2}{|c|}{ Local companies } & \multicolumn{2}{|c|}{ Foreign companies } \\
\hline & Accountant & Senior accountant & Accountant & Senior accountant \\
\hline & (1) & (2) & (3) & (4) \\
\hline Malaysia & $\begin{array}{c}-0.049 \\
(0.040)\end{array}$ & $\begin{array}{c}-0.038 \\
(0.048)\end{array}$ & $\begin{array}{c}-0.078 \\
(0.114)\end{array}$ & $\begin{array}{c}-0.160 \\
(0.080)^{*}\end{array}$ \\
\hline Singapore & $\begin{array}{c}-0.071 \\
(0.040)^{*}\end{array}$ & $\begin{array}{c}0.010 \\
(0.049)\end{array}$ & $\begin{array}{c}0.090 \\
(0.114)\end{array}$ & $\begin{array}{l}-0.031 \\
(0.079)\end{array}$ \\
\hline Female & $\begin{array}{c}0.056 \\
(0.041)\end{array}$ & $\begin{array}{c}0.043 \\
(0.044)\end{array}$ & $\begin{array}{c}0.187 \\
(0.110)^{*}\end{array}$ & $\begin{array}{c}0.051 \\
(0.069)\end{array}$ \\
\hline Rich neighborhood & $\begin{array}{l}-0.044 \\
(0.033)\end{array}$ & $\begin{array}{l}-0.046 \\
(0.040)\end{array}$ & $\begin{array}{l}-0.023 \\
(0.090)\end{array}$ & $\begin{array}{c}0.030 \\
(0.062)\end{array}$ \\
\hline Constant & $\begin{array}{c}0.181 \\
(0.083)^{* *}\end{array}$ & $\begin{array}{c}0.223 \\
(0.117)^{*}\end{array}$ & $\begin{array}{c}0.298 \\
(0.240)\end{array}$ & $\begin{array}{c}0.160 \\
(0.156)\end{array}$ \\
\hline Additional controls & & & & \\
\hline Resume template fixed effects & $X$ & $X$ & $\mathrm{X}$ & $X$ \\
\hline Week fixed effect & $\mathrm{X}$ & $\mathrm{X}$ & $\mathrm{X}$ & $\mathrm{X}$ \\
\hline Application letter fixed effects & $\mathrm{X}$ & $\mathrm{X}$ & $X$ & $\mathrm{X}$ \\
\hline $\mathrm{N}$ & 396 & 324 & 88 & 80 \\
\hline $\mathrm{R}^{2}$ & 0.087 & 0.054 & 0.233 & 0.300 \\
\hline
\end{tabular}


Table 26: Dependent variable: if a resume is the first to receive a callback for an interview

\begin{tabular}{|c|c|c|c|}
\hline \multirow{3}{*}{$\begin{array}{l}\text { Job category } \\
\text { Employer }\end{array}$} & \multicolumn{3}{|c|}{ Engineer } \\
\hline & $\begin{array}{l}\text { Local and foreign } \\
\text { companies }\end{array}$ & Local companies & Foreign companies \\
\hline & (1) & $(2)$ & (3) \\
\hline Malaysia & $\begin{array}{c}-0.006 \\
(0.031)\end{array}$ & $\begin{array}{l}-0.013 \\
(0.034)\end{array}$ & $\begin{array}{c}0.036 \\
(0.083)\end{array}$ \\
\hline Singapore & $\begin{array}{l}-0.006 \\
(0.031)\end{array}$ & $\begin{array}{l}-0.007 \\
(0.034)\end{array}$ & $\begin{array}{c}0.037 \\
(0.075)\end{array}$ \\
\hline Female & $\begin{array}{c}-0.053 \\
(0.028)^{*}\end{array}$ & $\begin{array}{l}-0.036 \\
(0.031)\end{array}$ & $\begin{array}{c}-0.102 \\
(0.070)\end{array}$ \\
\hline Rich neighborhood & $\begin{array}{c}-0.024 \\
(0.025)\end{array}$ & $\begin{array}{l}-0.027 \\
(0.028)\end{array}$ & $\begin{array}{l}-0.006 \\
(0.063)\end{array}$ \\
\hline Constant & $\begin{array}{c}0.146 \\
(0.062) * *\end{array}$ & $\begin{array}{c}0.105 \\
(0.066)\end{array}$ & $\begin{array}{c}0.331 \\
(0.181)^{*}\end{array}$ \\
\hline Additional controls & & & \\
\hline Resume template fixed effects & $\mathrm{X}$ & $\mathrm{X}$ & $\mathrm{X}$ \\
\hline Week fixed effect & $\mathrm{X}$ & $\mathrm{X}$ & $X$ \\
\hline Application letter fixed effects & $\mathrm{X}$ & $\mathrm{X}$ & $\mathrm{X}$ \\
\hline $\mathrm{N}$ & 752 & 594 & 158 \\
\hline $\mathrm{R}^{2}$ & 0.034 & 0.059 & 0.114 \\
\hline
\end{tabular}


Table 27: Dependent variable: if a resume is the first to receive a callback for an interview

\begin{tabular}{|c|c|c|c|}
\hline \multirow{3}{*}{$\begin{array}{l}\text { Job category } \\
\text { Employer }\end{array}$} & \multicolumn{3}{|c|}{ Civil engineer } \\
\hline & $\begin{array}{l}\text { Local and foreign } \\
\text { companies }\end{array}$ & Local companies & Foreign companies \\
\hline & (1) & $(2)$ & (3) \\
\hline Malaysia & $\begin{array}{l}-0.047 \\
(0.050)\end{array}$ & $\begin{array}{l}-0.060 \\
(0.056)\end{array}$ & $\begin{array}{c}0.030 \\
(0.130)\end{array}$ \\
\hline Singapore & $\begin{array}{l}-0.024 \\
(0.052)\end{array}$ & $\begin{array}{l}-0.012 \\
(0.059)\end{array}$ & $\begin{array}{l}-0.062 \\
(0.130)\end{array}$ \\
\hline Female & $\begin{array}{c}-0.083 \\
(0.046)^{*}\end{array}$ & $\begin{array}{c}-0.086 \\
(0.051)^{*}\end{array}$ & $\begin{array}{l}-0.087 \\
(0.123)\end{array}$ \\
\hline Rich neighborhood & $\begin{array}{c}0.014 \\
(0.041)\end{array}$ & $\begin{array}{c}0.011 \\
(0.047)\end{array}$ & $\begin{array}{c}0.046 \\
(0.099)\end{array}$ \\
\hline Constant & $\begin{array}{c}0.118 \\
(0.097)\end{array}$ & $\begin{array}{c}0.120 \\
(0.100)\end{array}$ & $\begin{array}{c}0.032 \\
(0.239)\end{array}$ \\
\hline Additional controls & & & \\
\hline Resume template fixed effects & $\mathrm{X}$ & $\mathrm{X}$ & $X$ \\
\hline Week fixed effect & $X$ & $\mathrm{X}$ & $\mathrm{X}$ \\
\hline Application letter fixed effects & $\mathrm{X}$ & $\mathrm{X}$ & $\mathrm{X}$ \\
\hline $\mathrm{N}$ & 300 & 230 & 70 \\
\hline $\mathrm{R}^{2}$ & 0.048 & 0.077 & 0.156 \\
\hline
\end{tabular}


Table 28: Dependent variable: If a resume receives a callback for a job interview

\begin{tabular}{|c|c|c|c|c|}
\hline \multirow{3}{*}{$\begin{array}{l}\text { Callback } \\
\text { Occupation }\end{array}$} & \multicolumn{4}{|c|}{ Job openings in which only one applicant receives a callback for an interview } \\
\hline & Software developer & Accountant & Engineer & Civil Engineer \\
\hline & (1) & $(2)$ & (3) & (4) \\
\hline Foreign & $\begin{array}{c}0.623 \\
(0.178)^{* * *}\end{array}$ & $\begin{array}{c}-0.182 \\
(0.095)^{*}\end{array}$ & $\begin{array}{c}0.230 \\
(0.099)^{* *}\end{array}$ & $\begin{array}{c}0.270 \\
(0.200)\end{array}$ \\
\hline Female & $\begin{array}{c}0.123 \\
(0.153)\end{array}$ & $\begin{array}{c}0.293 \\
(0.112)^{* *}\end{array}$ & $\begin{array}{l}-0.136 \\
(0.126)\end{array}$ & $\begin{array}{l}-0.419 \\
(0.267)\end{array}$ \\
\hline Rich neighborhood & $\begin{array}{c}0.163 \\
(0.205)\end{array}$ & $\begin{array}{c}-0.194 \\
(0.096)^{* *}\end{array}$ & $\begin{array}{l}-0.139 \\
(0.098)\end{array}$ & $\begin{array}{l}-0.210 \\
(0.193)\end{array}$ \\
\hline Constant & $\begin{array}{c}0.678 \\
(0.397)\end{array}$ & $\begin{array}{c}0.480 \\
(0.227)^{* *}\end{array}$ & $\begin{array}{c}0.266 \\
(0.372)\end{array}$ & $\begin{array}{c}0.291 \\
(0.450)\end{array}$ \\
\hline Additional controls & & & & \\
\hline Resume template fixed effects & $\mathrm{X}$ & $\mathrm{X}$ & $\mathrm{X}$ & $\mathrm{X}$ \\
\hline Week fixed effect & $\mathrm{X}$ & $\mathrm{X}$ & $\mathrm{X}$ & $\mathrm{X}$ \\
\hline Application letter fixed effects & $X$ & $\mathrm{X}$ & $X$ & $\mathrm{X}$ \\
\hline $\mathrm{N}$ & 22 & 122 & 106 & 38 \\
\hline $\mathrm{R}^{2}$ & 0.855 & 0.197 & 0.234 & 0.344 \\
\hline
\end{tabular}

sample restriction. ${ }^{*} \mathrm{p}<0.10 ; * * \mathrm{p}<0.05 ; * * * \mathrm{p}<0.01$. 


\section{REFERENCES}

Adams Jr, Richard H. 2011. "Evaluating the Economic Impact of International Remittances on Developing Countries Using Household Surveys: A Literature Review." Journal of Development Studies, 47(6), 809-28.

Aigner, Dennis J and Glen G Cain. 1977. "Statistical Theories of Discrimination in Labor Markets." Industrial and Labor relations review, 175-87.

Ambrosini, J William; Karin Mayr; Giovanni Peri and Dragos Radu. 2011. "The Selection of Migrants and Returnees: Evidence from Romania and Implications," National Bureau of Economic Research.

Ayres, Ian and Peter Siegelman. 1995. "Race and Gender Discrimination in Bargaining for a New Car." The American Economic Review, 304-21.

Barrett, Alan and Philip J O Connell. 2001. "Is There a Wage Premium for Returning Irish Migrants?" Economic and Social Review, 32(1), 1-22.

Beine, Michel; Frederic Docquier and Hillel Rapoport. 2008. "Brain Drain and Human Capital Formation in Developing Countries: Winners and Losers." The Economic Journal, 118(528), 631-52.

Bertrand, Marianne and Sendhil Mullainathan. 2004. "Are Emily and Greg More Employable Than Lakisha and Jamal:A Field Experiment on Labor Market Discrimination." American Economic Review, 94(991), 1013.

Bhagwati, Jagdish and Koichi Hamada. 1974. "The Brain Drain, International Integration of Markets for Professionals and Unemployment: A Theoretical Analysis." Journal of Development Economics, $1(1), 19-42$.

Butler, Daniel M and David E Broockman. 2011. "Do Politicians Racially Discriminate against Constituents? A Field Experiment on State Legislators." American Journal of Political Science, 55(3), 463-77.

Carletto, Calogero and Talip Kilic. 2011. "Moving up the Ladder? The Impact of Migration Experience on Occupational Mobility in Albania." Journal of Development Studies, 47(6), 846-69.

Clemens, Michael A. 2013. "Why Do Programmers Earn More in Houston Than Hyderabad? Evidence from Randomized Processing of Us Visas." The American Economic Review, 103(3), 198-202.

Connell, Julia; John Burgess; Jan Saarela and Fjalar Finnäs. 2009. "Return Migrant Status and Employment in Finland." International Journal of Manpower, 30(5), 489-506.

Darolia, Rajeev; Cory Koedel; Paco Martorell; Katie Wilson and Francisco Perez-Arce. 2014. "Do Employers Prefer Workers Who Attend for-Profit Colleges? Evidence from a Field Experiment."

De Coulon, Augustin and Matloob Piracha. 2005. "Self-Selection and the Performance of Return Migrants: The Source Country Perspective." Journal of Population Economics, 18(4), 779-807.

Di Maria, Corrado and Emiliya A Lazarova. 2012. "Migration, Human Capital Formation, and Growth: An Empirical Investigation." World Development, 40(5), 938-55.

Doleac, Jennifer L and Luke CD Stein. 2013. "The Visible Hand: Race and Online Market Outcomes." The Economic Journal, 123(572), F469-F92.

Dustmann, Christian; Itzhak Fadlon and Yoram Weiss. 2011. "Return Migration, Human Capital Accumulation and the Brain Drain." Journal of Development Economics, 95(1), 58-67.

Dustmann, Christian and Yoram Weiss. 2007. "Return Migration: Theory and Empirical Evidence from the Uk." British Journal of Industrial Relations, 45(2), 236-56.

Foged, Mette. 2010. "Wage Effects of International Return Migration."

Gang, Ira N and Myeong-Su Yun. 2000. "Returns to Returning." Journal of Population Economics, 13(1), 57-79.

Gibson, John and David McKenzie. 2012. "The Economic Consequences of 'Brain Drain' of the Best and Brightest: Microeconomic Evidence from Five Countries*." The Economic Journal, 122(560), 339-75.

. 2011. "The Microeconomic Determinants of Emigration and Return Migration of the Best and 
Brightest: Evidence from the Pacific." Journal of Development Economics, 95(1), 18-29.

Hamada, Koichi and Jagdish Bhagwati. 1975. "Domestic Distortions, Imperfect Information and the Brain Drain." Journal of Development Economics, 2(3), 265-79.

Kapur, Devesh and John McHale. 2005. "Give Us Your Best and Brightest: The Global Hunt for Talent and Its Impact on the Developing World."

Kroft, Kory; Fabian Lange and Matthew J. Notowidigdo. 2013. "Duration Dependence and Labor Market Conditions: Evidence from a Field Experiment*." The Quarterly Journal of Economics.

Lahey, Joanna N. 2008. "Age, Women, and Hiring an Experimental Study." Journal of Human Resources, 43(1), 30-56.

Martin, Reiner and Dragos Radu. 2012. "Return Migration: The Experience of Eastern Europe." International Migration, 50(6), 109-28.

Mayr, Karin and Giovanni Peri. 2009. "Brain Drain and Brain Return: Theory and Application to Eastern-Western Europe." The BE Journal of Economic Analysis \& Policy, 9(1).

McCormick, Barry and Jackline Wahba. 2001. "Overseas Work Experience, Savings and Entrepreneurship Amongst Return Migrants to Ldcs." Scottish journal of political economy, 48(2), 164-78.

. 2000. "Return Migration and Entrepreneurship in Egypt." University of Southampton, UK.

McKenzie, David. 2012. "Learning About Migration through Experiments," Centre for Research and Analysis of Migration (CReAM), Department of Economics, University College London,

McKenzie, David; Steven Stillman and John Gibson. 2010. "How Important Is Selection? Experimental Vs. Non-Experimental Measures of the Income Gains from Migration." Journal of the European Economic Association, 8(4), 913-45.

McKenzie, David and Dean Yang. 2010. "Experimental Approaches in Migration Studies." World Bank Policy Research Working Paper Series, Vol.

Milkman, Katherine L; Modupe Akinola and Dolly Chugh. 2014. "What Happens Before? A Field Experiment Exploring How Pay and Representation Differentially Shape Bias on the Pathway into Organizations." A Field Experiment Exploring How Pay and Representation Differentially Shape Bias on the Pathway into Organizations (July 11, 2014).

Neumark, David; Ian Burn and Patrick Button. 2015. "Is It Harder for Older Workers to Find Jobs? New and Improved Evidence from a Field Experiment," National Bureau of Economic Research,

Oreopoulos, Philip. 2011. "Why Do Skilled Immigrants Struggle in the Labor Market? A Field Experiment with Thirteen Thousand Resumes." American Economic Journal: Economic Policy, 3(4), 148-71.

Pager, Devah; Bruce Western and Bart Bonikowski. 2009. "Discrimination in a Low-Wage Labor Market a Field Experiment." American Sociological Review, 74(5), 777-99.

Phelps, Edmund S. 1972. "The Statistical Theory of Racism and Sexism." The American Economic Review, 659-61.

Reinhold, Steffen and Kevin Thom. 2013. "Migration Experience and Earnings in the Mexican Labor Market." Journal of Human Resources, 48(3), 768-820.

Saarela, Jan and Fjalar Finnäs. 2009. "Return Migrant Status and Employment in Finland." International Journal of Manpower, 30(5), 489-506.

Schulman, Kevin A; Jesse A Berlin; William Harless; Jon F Kerner; Shyrl Sistrunk; Bernard J Gersh; Ross Dube; Christopher K Taleghani; Jennifer E Burke and Sankey Williams. 1999. "The Effect of Race and Sex on Physicians' Recommendations for Cardiac Catheterization." New England Journal of Medicine, 340(8), 618-26.

Stark, Oded; Christian Helmenstein and Alexia Prskawetz. 1998. "Human Capital Depletion, Human Capital Formation, and Migration: A Blessing or a "Curse"?" Economics Letters, 60(3), 363-67.

Sun, Wei. 2013. "The Productivity of Return Migrants: The Case of China's "Sea Turtles"." IZA Journal of Migration, 2(1), 1-19.

Yang, Dean. 2008. "International Migration, Remittances and Household Investment: Evidence from Philippine Migrants' Exchange Rate Shocks." The Economic Journal, 118(528), 591-630. 
Appendix E: Distribution of Sample Job Openings

\begin{tabular}{lcc}
\hline \hline & Frequency & $\%$ \\
\hline Accountant & 242 & 24.97 \\
Senior accountant & 202 & 20.85 \\
Architect & 13 & 1.34 \\
Draftsmen & 22 & 2.27 \\
Software developer and programmer & 74 & 7.64 \\
IT technician & 62 & 6.40 \\
Civil engineer & 150 & 15.48 \\
Mechanical, electrical, and electronic engineer & 87 & 8.98 \\
General engineer & 7 & 0.72 \\
Junior civil engineer & 9 & 0.93 \\
Project engineer or project manager & 52 & 5.37 \\
Assistant chief engineer & 3 & 0.31 \\
Assistant engineer & 3 & 0.31 \\
Senior civil engineer & 8 & 0.83 \\
Sales engineer & 4 & 0.41 \\
Service engineer & 18 & 1.86 \\
Nurse or pharmacist & 11 & 1.14 \\
Other & 2 & 0.21 \\
\hline Total & 969 & 100 \\
\hline \hline
\end{tabular}


Appendix F: Distribution of Sample by Week

\begin{tabular}{cccccc}
\hline \hline Week & $\begin{array}{c}\text { Total job } \\
\text { openings }\end{array}$ & $\begin{array}{c}\text { Sample job } \\
\text { openings }\end{array}$ & $\begin{array}{c}\text { Resumes } \\
\text { submitted }\end{array}$ & $\%$ & Date (2015) \\
\hline 1 & 81 & 55 & 110 & 5.68 & March 23 - March 27 \\
2 & 78 & 58 & 116 & 5.99 & March 30 - April 3 \\
3 & 34 & 23 & 46 & 2.37 & April 6 - April 10 \\
4 & 136 & 71 & 142 & 7.33 & April 20 - April 24 \\
5 & 111 & 60 & 120 & 6.19 & April 27 - May 1 \\
6 & 87 & 54 & 108 & 5.57 & May 4 - May 8 \\
7 & 88 & 55 & 110 & 5.68 & May 11 - May 15 \\
8 & 93 & 52 & 104 & 5.37 & May 18 - May 22 \\
9 & 90 & 54 & 108 & 5.57 & May 25 - May 29 \\
10 & 114 & 64 & 128 & 6.60 & June 1 - June 5 \\
11 & 120 & 61 & 122 & 6.30 & June 8 - June 12 \\
12 & 125 & 57 & 114 & 5.88 & June 15 - June 19 \\
13 & 78 & 48 & 96 & 4.95 & June 22 - June 26 \\
14 & 78 & 39 & 78 & 4.02 & July 6 - July 10 \\
15 & 227 & 100 & 200 & 10.32 & July 13 - July 17 \\
16 & 147 & 58 & 116 & 5.99 & July 20 - July 24 \\
17 & 42 & 24 & 48 & 2.48 & July 27 - July 31 \\
18 & 30 & 17 & 34 & 1.75 & August 3 - August 7 \\
19 & 31 & 19 & 38 & 1.96 & August 10 - August 14 \\
\hline Total & 1,790 & 969 & 1,938 & 100 & \\
\hline \hline
\end{tabular}


Appendix G: List of Variables and Their Detailed Descriptions

\begin{tabular}{|c|c|}
\hline Variable & Description \\
\hline $\mathrm{Y}$ & $\begin{array}{l}\text { Dependent variables: (1) if a resume sent is the first to receive a callback, (2) if } \\
\text { a resume submitted receives a callback conditional on an employer calling back } \\
\text { only one applicant. }\end{array}$ \\
\hline Foreign & $\begin{array}{l}\text { A dummy taking a value of } 1 \text { if a resume is associated with foreign work } \\
\text { experience, } 0 \text { otherwise (local experience is the reference group). }\end{array}$ \\
\hline Malaysia & $\begin{array}{l}\text { A dummy taking a value of } 1 \text { if a resume is associated with work experience in } \\
\text { Malaysia, } 0 \text { otherwise (local experience is the reference group). }\end{array}$ \\
\hline Singapore & $\begin{array}{l}\text { A dummy taking a value of } 1 \text { if a resume is associated with work experience in } \\
\text { Singapore, } 0 \text { otherwise (local experience is the reference group). }\end{array}$ \\
\hline Template 1a & $\begin{array}{l}\text { A dummy taking a value of } 1 \text { if a resume is assigned template } 1 \mathrm{a}, 0 \text { otherwise } \\
\text { (template } 1 \mathrm{~b} \text { is the reference group). }\end{array}$ \\
\hline Template $2 \mathrm{a}$ & A dummy taking a value of 1 if a resume is assigned template $2 \mathrm{a}, 0$ otherwise. \\
\hline Template $2 \mathrm{~b}$ & A dummy taking a value of 1 if a resume is assigned template $2 b, 0$ otherwise. \\
\hline Female & $\begin{array}{l}\text { A dummy taking a value of } 1 \text { if a resume is associated with a female name, } 0 \\
\text { otherwise (male is the reference group). }\end{array}$ \\
\hline Rich & $\begin{array}{l}\text { A dummy taking a value of } 1 \text { if a resume is associated with a zip code in an } \\
\text { affluent neighborhood, } 0 \text { otherwise (poor neighborhood is the reference group). }\end{array}$ \\
\hline Week 1-19 & Dummies representing weeks when resumes were submitted. \\
\hline Emails 1 & Dummies representing application letters \# 1 (email \# 2 is the reference group). \\
\hline
\end{tabular}


Appendix H: List of skilled occupations

\begin{tabular}{|l|l|}
\hline Accountant & Nurse \\
\hline Architect & Pharmacist \\
\hline AUTO CAD Engineer & PHP Development \\
\hline Chief Accountant & Programmer \\
\hline Chief Civil Engineer & Project Engineer \\
\hline Civil Engineer & Quantity Surveyor \\
\hline Construction Engineer & Radiologist \\
\hline Construction Manager & Senior Accountant \\
\hline Design Engineer & Senior Civil Engineer \\
\hline Draft Man & Senior Network Engineer \\
\hline Electrical Engineer & Senior PHP Developer \\
\hline Electronic Engineer & Senior Software Developer \\
\hline Finance Controller & Senior Web Developer or Web Programmer \\
\hline Finance Manager & Site Engineer \\
\hline M \& E Engineer & Site Manager \\
\hline Maintenance Engineer & Software Developer \\
\hline Mechanical Engineer & Structural Engineer \\
\hline Network Engineer & Surveyor \\
\hline & Web Developer or Web Programmer \\
\hline
\end{tabular}


Appendix I: Location Maps of the Zip Codes used in Resumes

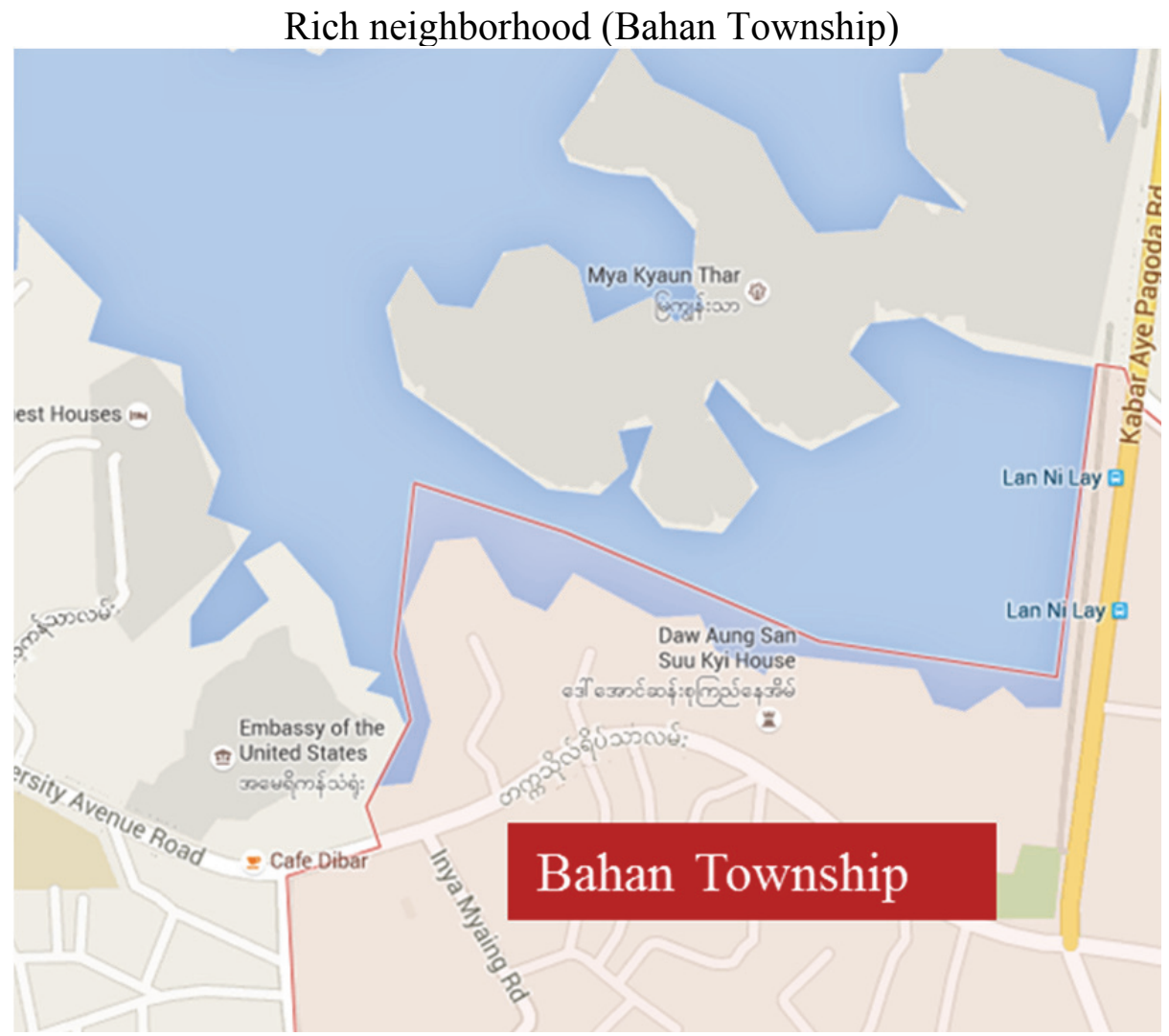

Poor neighborhood (North Okkalapa Township)

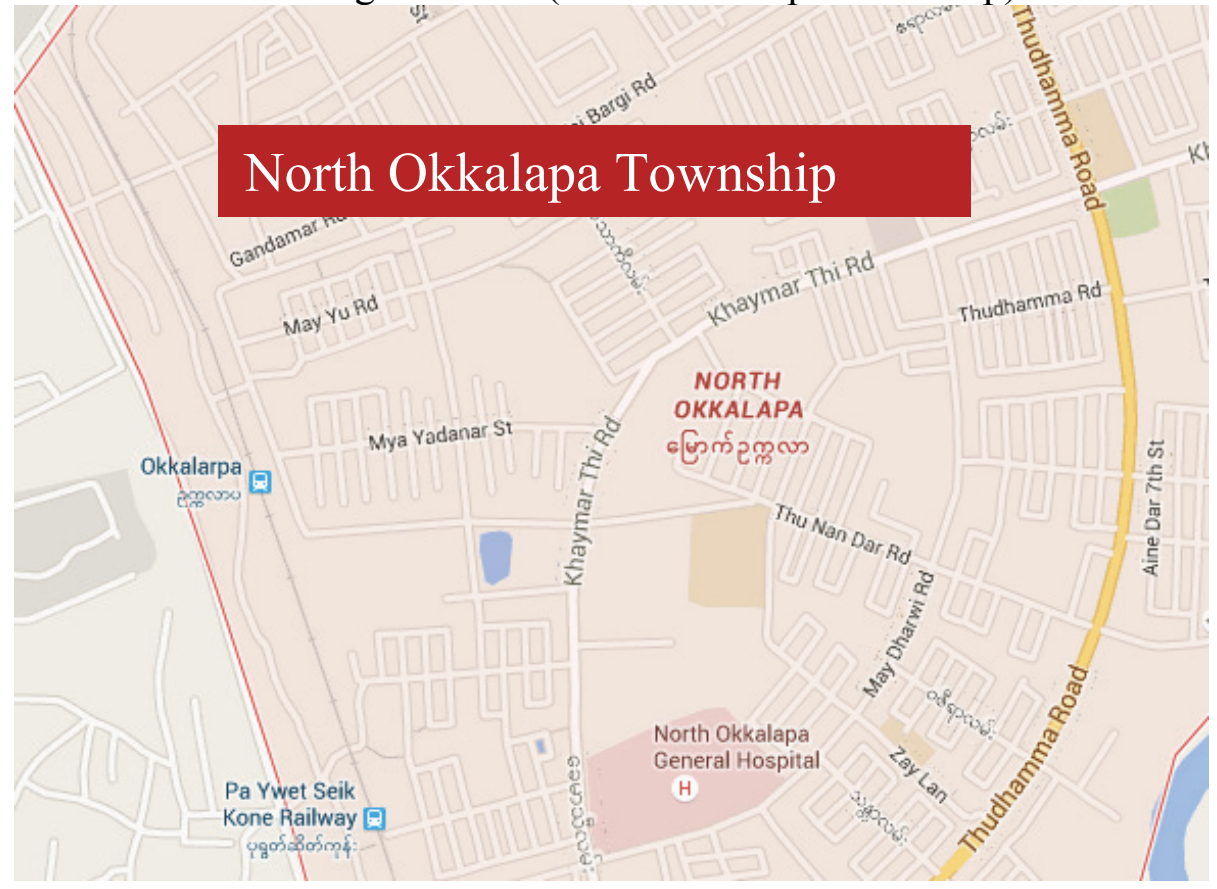




\section{Appendix J: Institutional Review Board (IRB) Approval}

Protocols, which form the basis for executing this research, were reviewed and approved by the Human Subjects Protection Committee at the RAND Corporation in March, 2015 (Assurance number is FWA00003425; IRB number is IRB0000005). The IRB does not allow me to release any identifying information about the employers including names and addresses.

However, I was allowed to preserve and use information on the job characteristics posted on the job advertisements. 


\title{
ESSAY 3
}

\section{Racial Discrimination in Myanmar Labor Markets: Evidence from a Field Experiment}

\author{
Saw Htay Wah
}

\begin{abstract}
This paper explores potential ethnic discrimination in Myanmar's labor market. Ethnic minorities constitute approximately $40 \%$ of the Myanmar population of 51 million. Yet, little is known about the experiences and context of ethnic groups in Myanmar and their labor market outcomes. Ample anecdotal evidence indicate that ethnic minorities are highly discriminated against in the public sector that is largely dominated by majority ethnic Burmans. Given this precedent in the public sector, minority communities are concerned that they will also be targets of discrimination in the private sector in which a majority of employers are majority Burmans. This study uses audit methodology to examine whether employers in the private sector discriminate against ethnic minorities. Overall, I do not find significant evidence suggesting that ethnic minorities are racially discriminated against. In contrast, one particular minority group, ethnic Karen, is found to be preferred by employers in the private sector, compared with ethnic Burman. As for other minority groups, there are no differences in employers' responses between ethnic minorities and majority Burman. The same analysis should be extended to the public and non-profit sectors given their economic significance. While audit studies have provided critical evidence about labor market discrimination in developed countries, this is the first labor market audit study performed in a developing country to uncover racial discrimination.
\end{abstract}




\section{INTRODUCTION}

Myanmar is an ethnically diverse country experiencing an unprecedented period of freedom and potential economic growth. There are 135 ethnic groups officially recognized by the Myanmar government, making it one of the most ethnically diverse countries in the world ${ }^{29}$. Despite this ethnic diversity, little is known about the experiences and context of ethnic groups in Myanmar, largely due to decades of isolation and severe political constraints that restricted research activities in the past decades.

Since its independence from Great Britain in 1948, Myanmar has been in a state of perennial civil war between the successive military governments (including the current one), whose leading members are predominantly drawn from the majority Burman population, and various ethnic minority armed groups, making it the longest civil war in the world today. ${ }^{30}$ It is this ongoing and evolving political relationship between the Myanmar government and the diverse minority armed groups -- coupled with ethnic diversity -- that makes Myanmar a unique case in racial and ethnic studies.

While only a fraction of the minority populations participate in the armed conflict, many pursue their economic lives within the legal boundaries permitted by the state and thus interact with the majority Burman population on a regular basis. It is these racial interactions taking place in the market places, particularly in the labor markets, which could subject members of ethnic minorities to racial discrimination, given a large numbers of employers tend to be majority Burmans. In fact, there are ample anecdotal evidence suggesting that ethnic minorities are highly discriminated against in the government sector dominated by Burmans (Center for Peace and

\footnotetext{
${ }^{29} \mathrm{https}: / /$ en.wikipedia.org/wiki/List_of_ethnic_groups_in_Myanmar

${ }^{30}$ As of today, there are 14 ethnic armed groups (http://www.mmpeacemonitor.org/). Of these 14 armed ethnic groups, 8 groups (The All Burma Students' Democratic Front, Arakan Liberation Party, Chin National Front, Democratic Karen Benevolent Army, Karen National Liberation Army-Peace Council, Karen National Union, Pa-O National Liberation Organization, Shan State Army-South) signed a ceasefire agreement with the Myanmar government on October 15, 2015 aimed at ending more than six decades of armed conflicts, while the three largest and most powerful ethnic armies (United Wa State Army, Kachin Independence Army, and Shan State Army-North) refused to enter the ceasefire agreement. The remaining three groups (the Ta'ang National Liberation Army, Myanmar National Democratic Alliance Army, and the Arakan Army) are not invited for ceasefire negotiations with the Myanmar government; intense fighting between the Burmese military and the three groups continue on a regular basis (http://www.irrawaddy.org/burma/burma-army-troops-clash-with-tnla-in-northern-shan.html ).

Despite the recent signing of a nationwide ceasefire agreement, fighting between government troops and some ethnic groups continues. See http://www.irrawaddy.org/election/news/burmas-minorities-fear-usdp-election-victory for the latest development.

For a comprehensive discussion on the origins and evolutions of ethnonational politics and armed conflict in Myanmar, see Thawnghmung (2011) and South (2008)).
} 
Conflict Studies, 2010; Thawnghmung, 2011). For instance, career prospects and upward career mobility (conditional on being employed) is very limited for ethnic minorities in the government sector (Center for Peace and Conflict Studies, 2010; Thawnghmung, 2011). Consequently, they are largely underrepresented (relative to their population shares) in the government sector, particularly in high-ranking government positions, and in the armed forces.

Given the abovementioned setting, minority communities are concerned that the prejudice and discrimination against them in the government sector could also happen in the private sector in which a majority of employers are majority Burmans.

This paper aims to explore if employers in the private sector racially discriminate. It focuses on the private sector because the total employment share of this sector has grown steadily in recent years due to an increase in foreign direct investment and the introduction of new policies aimed at strengthening the role of the private sector. It also focuses on five ethnic groups: majority ethnic Burman, and four ethnic minorities (Chin, Karen, Kachin, and Shan). These five ethnic groups combined account for over 80 percent of the Myanmar population of 51 million people. The four minority groups combined represent over 50 percent of all minority populations and each has a history of ethno-nationalist movement. The following succinctly discuss the background history of each of the five ethnic groups.

Burmans are majority ethnic with a population estimated at 31 million, based on a population share of 60 percent of 51 million people (Government of Burma, 1986; The Myanmar Census, 2014) ${ }^{31}$. Most Burmans are Buddhists and historically dominate the government sector, in particular the upper echelons of the government, and the armed forces. The majority Burman population tends to spread out across the country, with a large concentration in the Irrawaddy river basin, the central region, and plains of Burma.

Shans are the largest minority group and their number are estimated at 4 to 5 million based on a population share of $8.5 \%$ of 51 million (Government of Burma, 1986; The Myanmar Census, 2014). A majority of Shans are also Buddhists and live in the Shan state located in northeastern Burma. The Shan state is home to three armed resistance organizations. One of them, the Shan State Army-South, has signed a ceasefire agreement with the central government recently, while the others, the United Wa State Army and the Shan State Army-North, have

\footnotetext{
${ }^{31}$ Data on ethnic population shares are from the 1983 Census. Data on the current Myanmar population is from the 2014 Census. The 2014 Census collected household and individual information (including race and ethnicity) across the country. However, data on ethnic populations from the 2014 Census are not readily available.
} 
refused to enter into a ceasefire agreement. Following the refusal, intense fighting and hostilities between the Myanmar military and the Shan State Army-North have intensified in the past weeks, displacing hundreds of villagers in central Shan state ${ }^{32}$.

The first minority group to rise against the government shortly after the country gained independence from Great Britain in 1948, the Karens are the second largest minority with a population estimated at 3 to 4 million, based on a population share of 6 percent (Government of Burma, 1986; The Myanmar Census, 2014). Over half of Karens are Buddhists, 15 to 20 percent Christians, and 5 to 10 percent animists (Thawnghmung, 2011). The Karen Nation Union (KNU), a political organization representing the Karen ethno-nationalist movement, signed a formal ceasefire agreement with the Myanmar government on October 15, 2015, ending more than half a century of fighting between the Karen rebels and the Myanmar military. During the colonial period, the Karens disproportionately dominated the British civil service and military staff, and were perceived favorably (Thawnghmung, 2011). The favorable images about Karens that emerged during the colonial period have remained largely intact in contemporary Burmese society despite decades of armed struggles against the Burmese military. For instance, a large number of Karens (relative to their population share) are employed in the non-profit sector such as foreign embassies, international NGOs, and intergovernmental organizations (Center for Peach and Conflict Studies, 2010; Thawnghmung, 2011).

The Kachins inhabit the Kachin hills in northern Burma's Kachin state and neighboring areas of China and India. The numbers of Kachins are estimated to be at 1 million based on a population share of 2 percent. A majority of Kachins (close to 100\%) are Christians of Protestant denomination. Most armed groups in the Kachin state signed ceasefire agreement with the then military regime in the 1990s, but fighting between the Kachin Independent Army (KIA), the military wing of the Kachin Independence Organization (KIO), and the Burmese military resumed in 2011 following the KIA's refusal to transform its army into a border guard force. Like the Shan State Army-North, the KIA has refused to sign a ceasefire agreement with the central government in October, 2015. Consequently, the Burmese military's offensive against the KIA has intensified since ${ }^{33}$.

\footnotetext{
${ }^{32} \mathrm{http}$ ://www.irrawaddy.org/burma/aerial-assaults-as-shan-state-conflict-intensifies.html, http://www.irrawaddy.org/burma/mp-appeals-for-aid-to-displaced-in-conflict-riven-shan-state.html ${ }^{33} \mathrm{http}$ ://www.irrawaddy.org/burma/burma-army-offensive-continues-in-kachin-state.html
} 
The Chins mostly live in western part of Burma in Chin state. One estimate puts the number of Chins at 1.5 million $^{34}$. The ethno-nationalist movement representing the Chins is spearheaded by the Chin National Front (CNF). Compared to others, its armed group, the Chin National Army (CNA), was established relatively late, in 1988. The Chin National Front is also one of the armed minority groups to have entered into a ceasefire agreement with the Myanmar government on October 15, 2015. Thus, hostilities between this group and the Myanmar military have significantly lessened in recent months. Like the Kachins, a majority of Chins are Christians, most belonging to Protestant denominations, particularly Baptist.

Examining if members of each of the aforementioned minority groups are discriminated against by employers using observational data is difficulty because unobserved characteristics could explain the differences in outcomes. Similarly, a study relying on qualitative interviews has the potential for being affected by social desirability bias as participants realize that they are participating in a study involving a socially sensitive issue, thus may give responses in a manner that is socially acceptable.

One way to overcome these methodological issues will be to rely on an audit method to ensure that ethnic majority and minority groups are similar in all observable and unobservable characteristics, except for one important dimension - ethnicity. Further, the audit method also helps rule out social desirability bias because participants are not aware of the study. Thus, any observed differences in outcomes between these two groups can solely be attributed to differences in race and ethnicity. The resume auditing method has proven quite useful for studying differences in labor outcomes by race (Bertrand and Mullainathan, 2003), age (Lahey, 2008; Neumark et al., 2015), length of unemployment (Kroft et al., 2013), college education (Martorell et al, 2014), and nationality (Oreopoulos, 2011). However, this method has been limited to understanding labor markets in the United States and Canada.

In this paper, I present results from a resume audit study to examine if employers in the private sector racially discriminate. To my knowledge, this is the first labor market audit study performed in a developing country, and I discuss the challenges that must be considered in this context. Hundreds of fictitious resumes were submitted online in response to job openings in skill-intensive occupations in the Yangon area of Myanmar. The resumes were randomly assigned whether an applicant was a majority ethic Burman or a minority ethnic belonging to one

\footnotetext{
${ }^{34} \mathrm{http}$ ://www.oxfordburmaalliance.org/ethnic-groups.html
} 
of the four minority groups considered in this analysis. One of the contributions of this paper is to understand the heterogeneous responses by ethnic groups.

Overall, I do not find evidence suggesting that ethnic minorities are treated differently, but this aggregate effect masks group-specific heterogeneity. In contrast, one minority group, ethnic Karen, is found to be favored by employers. Specifically, resumes with a Karen-sounding name are 5.9 percentage points more likely to receive first callbacks for interviews than resumes with a Burman-sounding name. Based on this point estimate, ethnic Karen applicants are 46 percent more likely to receive first callbacks than ethnic Burman applicants, and this point estimate is robust to the inclusion of controls. I reach the same conclusion when selecting on employers that call back only one applicant out of two. When deciding to call back only one applicant, employers are 35 percentage points more likely to call back ethnic Karen applicants than ethnic Burman applicants. This point estimate represents a 100 percent difference in callbacks and is unaffected by the inclusion of additional controls. Put differently, these results suggest that on average a Karen applicant should expect to receive 7 callbacks for interview for every 10 applications he/she submitted in which employers call back only one applicant (out of two). On the other hand, a Burman applicant would need to submit 20 applications to achieve the same result. As for the remaining three minority groups (Chin, Kachin, Shan), there are no significant differences in callback rates between minority applicants and Burman applicants, suggesting no racial discrimination.

The rest of the paper is organized as follows. Section 2 surveys existing literature on discrimination, Section 3 presents the experimental design in details, and describes the data used in this analysis. Section 4 details the empirical analysis and Section 5 presents the results. Section 6 summarizes key findings and discusses their policy implications, which are followed by suggestions for future research.

\section{RELATED LITERATURE}

This research contributes to a growing literature on field-based discrimination studies. Pager et al. (2009) finds that, when applying for jobs in the low-wage labor market of New York City, Blacks are 50 percent less likely to receive callbacks for interviews or job offers than otherwise equivalent Whites; Blacks and Latinos with no criminal backgrounds are as equally likely as White applicants just released from prison to receive callbacks or job offers. Bertrand 
and Mullainathan (2004) find that resumes with White sounding names submitted to employers in two cities (Boston and Chicago) are 50 percent more likely to receive callbacks than resumes with African American sounding names. Oreopoulos (2011) finds that English sounding names are 39 percent more likely to receive callbacks from employers than Chinese, Indian, or Pakistani names in the labor markets in the Greater Toronto Area.

In addition to labor market outcomes, race is found to have differential impacts on other important economic and social outcomes. Anwar et al. (2012) exploit random variations in the composition of the jury team to analyze the causal impact of jury racial composition on trial outcomes. The authors find strong evidence that All White juries convict Black defendants at a 16 percentage points higher rate than White defendants, and this racial gap in conviction rates disappears when the juries include at least one Black member. Milkman et al. (2014) find that, when contacted by prospective $\mathrm{PhD}$ students requesting to discuss research opportunities, faculties are significantly more likely to ignore requests from minority applicants. Schulman et al. (1999) find that Black patients with chest pain are less likely than White patients to be referred for cardiac catheterization. When bargaining for a new car, Blacks are quoted a significantly higher price than Whites by dealers (Ayres and Sieglman, 1995). Doleac and Stein (2013) analyze race effects on market outcomes by selling iPods online and conveying the race of the seller through the skin color of the hand holding the iPod. The authors find that Black sellers receive fewer and lower offers than White sellers, and buyers significantly trust Black sellers less than White sellers. In the market for new houses, Turner (2013) reports that Black homeowners learn about 17 percent fewer available homes than equally qualified Whites and are shown 18 percent fewer homes. Likewise, Black renters learn about 11 percent fewer available rental units than equally qualified Whites and are shown 4 percent fewer rental units.

In addition to race-based discrimination, discrimination on the basis of gender, age, and employment status has been documented in prior studies. Goldin and Rouse (2000) find that the adoption of a "blind" audition with a "screen" aimed at concealing a candidate's identity from judges increases the probability that a woman will be hired for symphony orchestras. Milkman et al. (2014) find that female prospective PhD students are significantly less likely to receive responses from faculties when requesting to discuss research opportunities by emails. Lahey (2008) finds that younger workers are 40 percent more likely to receive callbacks for a job interview than older workers. Kroft et al. (2013) find that resumes listing an eight month 
unemployment spell are 45 percent less likely to receive callbacks for an interview than resumes listing a one month unemployment spell.

The current literature on discrimination has been restricted to settings in developed countries, particularly in the US (e.g., Bertrand and Mullainathan, 2004; Kroft et al., 2013; Lahey, 2008 ; Ayres and Siegelman, 1995; Schulman et al., 1999; Neumark et al., 2015) and Canada (Oreopoulos, 2011), and studies conducted in developing country settings are completely lacking. This current paper aims to fill this literature gap.

\section{EXPERIMENTAL DESIGN}

This is the first labor market audit study performed in a developing country and differs in some respects to audit studies conducted in the United States and Canada due to additional constraints and challenges that one faces with this type of research in a developing country. While prior studies have applied auditing methodology to study discrimination in the labor markets in the U.S. (e.g., Lahey, 2008; Bertrand and Mullainathan, 2004; Kroft et al., 2013), and in Canada (Oreopoulos, 2011), I find no precedent for studies applying the methodology to a setting in a developing country. This context presents problems for the audit method.

Successful implementation of resume audit studies depends on a high percentage of the population having access to internet and using email as the main channel of communications. This is not the case in many countries, particularly in developing countries. According to Internet World Stats statistics ${ }^{35}$, less than 2 percent of the Myanmar population has access to internet. This study sends applications by email (consistent with the literature), though there are concerns about the types of employers that accept applications by email compared to employers that will not be in our study (those that do not accept applications by email).

The implementation of this study and analysis of the data were also altered due to some of the unique - relative to the literature - challenges faced by conducting this method in Myanmar. First, employers in Myanmar do not rely as heavily on resumes in terms of screening applicants and inferring productivity, especially compared with other countries. Rather, personal interview combined with oral examination about knowledge on relevant subjects is still the preferred methods for screening applicants. Second, the marginal cost to interview an applicant is very low. These factors result in a high percentage of applicants being interviewed for a job

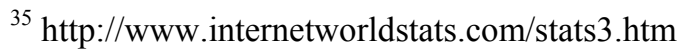


opening, making resumes relatively less effective as a screening device and thus weakening the effects of listing any resume characteristics (e.g., race).

Moreover, in prior audit studies, information regarding whether a resume submitted receives a callback is retrieved from content of voice message left by employer. Unlike in other countries, voice mailbox service is not available in Myanmar as the telecommunication industry is still in its early development stage. Whenever an employer calls back, a trained auditor pretending to be the applicant has to answer the call and is instructed to mention to employer over the phone that he/she is no longer interested in the employment opportunity. As a result, the employer is more likely to call back the second applicant for an interview.

Given evidence that many employers are simply calling back all applicants, an audit study approach is less likely to detect discrimination in this context. My analysis focuses on outcomes which will partially circumvent this issue. These concerns suggest that the more appropriate outcomes to uncover an employer' interest in an applicant for this analysis will be (1) if a resume submitted is the first to receive a callback for an interview, and (2) if a resume submitted receives a callback for an interview conditional on an employer calling back only one applicant. The first outcome produces variation even when employers callback both applicants and some of this variation may be informative about preferences. The second outcome eliminates employers that are calling back all applicants. It does not induce selection bias since it is selecting (implicitly) on a firm fixed effect. By including both applicants in the pair in the analysis, I am not creating selection bias. Instead, I am simply focusing in on firms more likely to be making active decisions based on the resumes.

Given the constraints of working in a small developing country and the small number of new job openings available each week, achieving a large sample size comparable to that of previous audit studies conducted in US was difficult so the analysis has less power than those found in the literature, primarily resulting from characteristics of the Myanmar job market.

\section{a. Resume Construction}

Preparation of the resumes began with listing the job requirements from the job advertisements and preparing resumes meeting those requirements in terms of educational attainment, years of work experience, salary requirement, and relevant computer skills. For each job posting, I prepared two resumes, and for each resume, I randomized the following four variables: (1) ethnicity (majority Burman/ethnic minority), (2) ethnic minority groups 
(Shan/Karen/Kachin/Chin) conditional on a resume being assigned ethnic minority, (3) gender (male/female), and (4) neighborhood (rich/poor).

Each resume listed the job title, period of employment, and company name of an applicant's recent three jobs in chronological order. The total years of work experience listed in the resume were always the same for both applicants and met the job requirement. Similarly, age of applicant, year of graduation, college major, university, computer skills, and other related skills were the same for both resumes. It is unlikely that employers in the Myanmar labor markets would suspect that these resumes were not submitted by real applicants. The resumes themselves were designed based on a large pool of actual resumes used by applicants in the Myanmar market. While each employer was sent two resumes, they were sent at least a day apart. Because the number of features randomized by the experiment was large, it was unlikely that the resumes would have similarly listed characteristics to describe the applicants. Furthermore, different fonts and layouts were used for each resume sent to an employer. The font and layout choices were also randomized. It is very likely that employers viewed each resume as an independent applicant.

Ethnicity of an applicant was conveyed to employers through the name listed in the resume, as well as through email as the name appearing in an applicant's email is the same as an applicant's name listed in the resume. Appendix K lists the names used in this research, broken down by ethnic group and gender. Note that each ethnic group has distinct names, particularly first name, for both male and female. Thus, ethnicity of an applicant can be readily identified from the name without ambiguity. Gender of an applicant was conveyed through name, as well as mentioned in the resume. Name of an applicant was always listed at the top of the resume with a large font size. Address and contact information were listed below the name. One of the two resumes submitted to each job opening was randomly assigned an address in Bahan Township, one of the most prosperous townships in Yangon, and the other an address in North Okkalapa Township, one of the most impoverished townships in Yangon. Each resume was randomly assigned a template and a cover letter.

Finally, resumes were saved as word files and randomly submitted via emails (independent of any resume characteristics) to the employers over a two-day period (Wednesday to Thursday) in each of the 19 weeks between March 23, 2015 and August 10, 2015. 
Unsuccessful applications due to incorrect employers' email addresses, which constitute less than $1 \%$ of the sample, were dropped from the sample.

\section{b. Sample and data}

The sample for job openings is from a popular magazine among job seekers in Myanmar (Opportunity; http://www.opportunity.com.mm/). The magazine carries only job advertisements, is published weekly, and accounts for approximately $90 \%$ of all job advertisements in the country. Job openings are classified by industrial sector: (1) production and manufacturing, (2) construction, (3) tourism, (4) IT, (5) trading, (6) service, and (7) Nongovernment organizations (NGO) and international non-government organizations (INGO). I restrict the sample to (1) skill-intensive and professional job categories, (2) job openings that require applicants to submit resumes via email, and (3) non-NGO and non-INGO jobs.

The final sample consists of 1,938 resumes submitted to 969 sample job openings. I restrict the sample to one randomly selected job opening per employer although several employers list multiple job openings in a given week. Appendix L shows the distribution of the total number of job openings, sampled job openings, and resumes sent by week. Error! Reference source not found. lists the distribution of sample job openings, broken down by occupation.

Table 29 presents results for mean equality tests of the randomly assigned resume characteristics to investigate if they are balanced between ethnic Burman and ethnic minority applicants. The last column reports the p-values, with the null being that the means are equal between majority and minority applicants. The results suggest that randomization is successful. I also provide results with and without these additional controls. Given that they are randomized, the inclusion of these controls should not matter and my results suggest that, in practice, do not.

Data for this research are from three sources: (1) the randomly assigned resume characteristics; (2) the job and employer characteristics from the job advertisements; and (3) the employer response (i.e., interview callback, no interview callback).

\section{EMPIRICAL ANALYSIS}

This section discusses how the outcomes and treatment variables are defined, the covariates entering the regressions, and the various specifications used for the estimations. 


\section{a. Dependent Variables}

I consider two outcomes in this analysis: (1) if a resume sent is the first to receive a callback for interview (this outcome is realized when either one of the two resumes submitted receives a callback, or both resumes receive a callback), (2) if a resume receives a callback conditional on job openings in which only one applicant receives a callback. I define a callback as a message from an employer asking an applicant over the phone to set up an interview.

In prior resume audit studies (i.e., Bertrand and Mullainathan, 2004; Kroft et al., 2013; Lahey, 2008; Oreopoulos, 2011), the primary outcome is if a resume submitted receives a callback for interview. I study an additional outcome because of the additional information it provides in this context. This study finds that a majority of employers call back at least one of the fictitious applicants and the average callback rate is $22 \%$ (Table 30 ), which is much higher than the 3-5\% callback rate found in prior studies. Sample statistics from Table 30 reveal that of 969 sample job openings, $72 \%$ result in no callbacks, $13 \%$ in a callback to one of the two applicants, and $15 \%$ in callbacks to both applicants.

\section{b. Independent Variables}

Table 31 reports descriptive statistics of the independent variables. As for treatment assignment, of 1,938 resumes submitted, half are associated with ethnic minority applicants. Conditional on being assigned ethnic minority, $27 \%$ of resumes are associated with ethnic Shan, $24 \%$ with ethnic Karen, 24\% with ethnic Kachin, and 26\% with ethnic Chin.

Each of the four resume templates is equally represented in the sample. About $52 \%$ of resumes are female, and 50\% are associated with the rich neighborhood. The average age of applicants is approximately 27 years, and half of sample resumes are assigned cover letter \# 1 .

\section{c. Empirical Models}

To examine if employers discriminate against minority applicants, I will estimate the following specification.

$$
Y_{i j t}=\beta_{0}+\beta_{1}^{*} \text { minority }_{i j t}+\omega X_{i j t}+\gamma_{t}+\varepsilon_{i j t}
$$

The list of variables entering the regressions and their detailed explanations are provided in Appendix M. For each specification and sample restriction, I will report the results with and without controls. OLS regression will produce unbiased estimates of the race effects, as long as 
any omitted variables are uncorrelated with the race variable. The primary estimates should be robust to the inclusion of controls if there are no systemic differences in controls between majority and minority applicants other than racial difference. The controls include resume characteristics $X_{i j t}$ (for resume $i$ submitted to job $j$ in week $t$ ) and a set of dummies $\left(\gamma_{t}\right)$ representing the week $t$ in which resumes were submitted. Including controls will help reduce unexplained error, thereby improving the statistical precision of the primary estimates.

To further investigate if there is a significant difference in callbacks between ethnic Burman applicants and applicants belonging to each of the four minority groups, I will compare their callback rates and test for their statistical significance. All standard errors are adjusted for clustering at employer level (Bertrand and Mullainathan, 2004; Oreopoulos, 2011).

\section{RESULTS}

\section{a. Main results}

Table 32 presents the main results (the reference group is resumes listing Burman names). The results in Column (1) indicate that there is no difference in first callback rates between resumes with Burman-sounding names and minority-sounding names. This point estimate is not affected by the inclusion of additional controls (Column (2)).

Next, I investigate if callbacks are systematically different across ethnic groups. Table 33 presents the results when I include dummies for each of the four minority groups (with the reference group being ethnic Burman applicants).

The results in Column (1) indicate that on average a Karen-sounding name is 5.9 percentage points more likely to receive a callback first than a Burman-sounding name. This difference is significant at the 5\% level and is unaffected by the inclusion of additional controls in Column (2). Based on this point estimate, ethnic Karen applicants are 44 percent more likely to receive callbacks first than ethnic Burman applicants (the baseline estimate is 13.3 percent). It is useful to compare the estimated effect of listing ethnic Karen names to those of other resume characteristics found in prior resume audit studies. Bertrand and Mullainathan (2004) find that resumes with White sounding names are 50 percent more likely receive callbacks than resumes with African American sounding names. Oreopoulos (2011) finds that English sounding names are 39 percent more likely to receive callbacks from employers than Chinese, Indian, or Pakistan 
names. Lahey (2008) finds that younger workers are 40 percent more likely to receive callbacks than older workers. Kroft et al. (2013) find that resumes listing an eight month of unemployment spell are 45 percent less likely to receive callbacks than resumes listing a one month of unemployment spell.

While ethnic Karens are significantly more likely to receive first callbacks for interview than majority ethnic Burmans, the remaining minority applicants (Chin, Kachin, and Shan) are as equally likely to receive first callbacks for interview as Burmans, and the results are robust to the inclusion of additional control in Column (2).

\section{b. By pair resumes (Outcome: only one applicant receives callback)}

Since I submitted two resumes (one Burman applicant and one minority applicant) to each job application, another way to analyze if employers make hiring decisions on the basis of race will be to select on employers that only call back one applicant and analyze patterns of employers' responses across 4 different pairs of resumes: (1) Burman applicants Vs Chin applicants, (2) Burman applicants Vs Karen applicants, (3) Burman applicants Vs Kachin applicants, and (4) Burman applicants Vs Shan applicants.

Table 34 presents the results, which are qualitatively similar to those presented in Table 33. The results in Column (1) suggest that, when deciding to call back only one applicant between ethnic Karens and majority Burmans, employers are 35 percentage points more likely to call back Karen applicants than ethnic Burman applicants. This difference is significant at the $1 \%$ level and unaffected by the inclusion of additional controls in Column 2, and represents a 109 percent difference in callbacks between ethnic Karen and Burman (baseline estimate is $32.4 \%$ for Burman applicants). Put differently, the point estimate suggests that for every 10 pairs of resumes submitted to employers who call back only one applicant in each resume pair, a Karen applicant should expect to receive 7 callbacks. On the other hand, a Burman applicant will require 21 such resume pairs to achieve the same result.

The results in Table 34 reveal that resumes with Kachin-sounding names generate fewer callbacks than resumes with Burman-sounding names. Specifically, when deciding to call back only one applicant between Kachin and Burman applicants, employers are on average 15 percentage points less likely to call back Kachin applicants and this represents a 27 percent difference in callback rates. However, the coefficient fails to be significant. When controls are included, the coefficient of listing Kachin names becomes more negative and is marginally 
significant (Column (6)). As for Chin applicants, employers are found to be indifferent between Burman and Chin applicants, thus are as equally likely to call back Burman applicants as Chin applicants (Column (3) \& (4)). Resumes with a Shan-sounding name are on average 7.7 percentage points more likely to receive callbacks than resumes with a Burman-sounding name, but the difference is not significant.

\section{CONCLUSION}

The underdevelopment of the labor market is one of the fundamental economic challenges that have yet to be addressed by the leadership in Burma. This study examines one particular constraint, racial discrimination in the labor market, which can be an impediment to the development of the labor market. This is especially so in Burma where there are 135 ethnic groups and armed conflicts between various ethnic minorities and the Burmese military dominated by majority ethnic Burmans are still ongoing.

In this study, I utilize resume audit method to examine if ethnic minorities are racially discriminate against. It focuses on the private sector employment given the growing economic significance of this sector in recent years due to an increase in foreign direct investment and the introduction of new policies aimed at promoting the role of the private sector. It also focuses on ethnic Burman that makes up approximately 60 percent of the Myanmar population of 51 million people and four minority groups that combined account for 50 percent of the minority populations and have a long history of ethno-nationalist movements.

Overall, I do not find significant evidence suggesting that ethnic minorities are racially discriminated against. In contrast, one particular minority group, ethnic Karen, is found to be favored by employers in the private sector. In particular, ethnic Karen applicants are on average 5.9 percentage points more likely to receive first callbacks than ethnic Burman applicants. This difference represents a 44 percent difference in first callback rates between ethnic Burman and Karen applicants, and is statistically significant at the 5\% level. In contrast, resumes listing ethnic Chin, Kachin, and Shan names receive as many first callbacks as resumes listing Burman names, indicating no racial discrimination against these minority groups.

I reach the same conclusion when focusing on employers that only call back one applicant out of two. Specifically, employers are 35 percentage points more likely to call back ethnic Karens than Ethnic Burmans when deciding to call back only one applicant among pairs 
of resumes that match Karen and Burman applicants. This difference represents a 109 percent difference in callbacks between resumes with a Burman-sounding name and a Karen-sounding name. As for the remaining three minority groups, employers are as equally likely to call back minority applicants as Burman applicants.

While this study is not designed to test theories of discrimination and uncover the underlying reasons for discrimination, the fact that employers favor one minority group (ethnic Karen) seems to be consistent with statistical discrimination that judges an individual based on group (rather than individual) characteristics. This could well be the case with the Karens, particularly Christian Karens, who are perceived among Burmese citizens as having relatively better English language skills (Center for Peach and Conflict Studies, 2010; Thawnghmung, 2011).

While findings from this study, the first of its kind, shed some light on the relationship between labor market outcomes and race, one should be careful not to interpret these results as evidence revealing racial discrimination in the labor market in Burma. More research is needed to uncover additional variations in the labor market outcomes across employment sectors, employers, racial groups, and their interactions before firm conclusions can be established. Specifically, the same analysis should be extended to the public sector employment, given the government alone accounts for 10 to 20 percent of the total employment (Thawnghmung, 2011). Further, there have been persistent complaints from members of ethnic minorities that they are often the targets of racial discrimination in the public sector, citing their underrepresentations in the military and in high-ranking government positions as evidence (Center for Peach and Conflict Studies, 2010; Thawnghmung, 2011). If these complaints are proven to be true, this could have implications for the ability of the public sector in attracting and retaining talented and high-caliber individuals, as well as for the ongoing peace process. Like the private sector, the number of employment in the non-profit sector has steadily increased in recent years due to an increase in the number of aid and development agencies, international and local NGOs, and community-based organizations (Thawnghmung, 2011). Despite this employment growth, many ethnic Burmans feel being discriminated against in this sector (Center for Peach and Conflict Studies, 2010; Thawnghmung, 2011). Thus, it is equally important to extend the same analysis to the non-profit sector. 
When it comes to addressing racial discrimination in the labor market, the US offers an excellent case study. Anti-racial discrimination policies have been successfully implemented (albeit with mixed results) by the federal government, state and local governments, as well as private entities in the US. A case study analyzing the various aspects of each of these policies and how they can be adapted and applied to the settings in Burma will be extremely desirable and helpful.

While audit studies have provided critical evidence about labor market discrimination in developed countries, this is the first labor market audit study performed in a developing country. As such, it discusses the additional constraints and challenges one faces with this type of research in a developing country. It then demonstrates the feasibility of conducting audit study in this setting by proposing additional measures to circumvent the challenges associated with the implementation and analysis of the data. 
Table 29: Randomization Tests

\begin{tabular}{lccc}
\hline \hline & Sample Means & \\
\cline { 2 - 3 } & Majority & Minorities & $\begin{array}{c}\text { p-value of test } \\
\text { of mean } \\
\text { equality }\end{array}$ \\
\hline Resumes associated with template 1a & 0.26 & 0.24 & 0.37 \\
Resumes associated with template 1b & 0.24 & 0.26 & 0.21 \\
Resumes associated with template 2a & 0.26 & 0.24 & 0.21 \\
Resumes associated with template 2b & 0.24 & 0.26 & 0.37 \\
Female applicants & 0.53 & 0.51 & 0.47 \\
Resumes associated with rich & 0.51 & 0.49 & 0.26 \\
neighborhood & 0.51 & 0.49 & 0.44 \\
Resumes associated with cover letter \#1 & & & \\
\hline \hline
\end{tabular}

Table 30: Descriptive Statistics for Callbacks

\begin{tabular}{lllll}
\hline \hline & $\mathrm{N}$ & Mean & Min & Max \\
\hline Resume is the first to receive a callback for interview & 1,938 & 0.14 & 0 & 1 \\
Resume receives a callback for interview & 1,938 & 0.22 & 0 & 1 \\
Job openings in which no applicants receive callbacks & 969 & 0.72 & 0 & 1 \\
Job openings in which only one applicant receives callback & 969 & 0.13 & 0 & 1 \\
Job openings in which both applicants receive callbacks & 969 & 0.15 & 0 & 1 \\
\hline \hline
\end{tabular}

Table 31: Descriptive Statistics of Independent Variables

\begin{tabular}{lcccc}
\hline \hline & $\mathrm{N}$ & Mean & Min & Max \\
\hline Treatment Variables & & & & \\
Minority applicants & 1,938 & 0.50 & 0 & 1 \\
Shan | Minority applicants & 969 & 0.27 & 0 & 1 \\
Karen | Minority applicants & 969 & 0.24 & 0 & 1 \\
Kachin | Minority applicants & 969 & 0.24 & 0 & 1 \\
Chin| Minority applicants & 969 & 0.26 & 0 & 1 \\
Covariates & & & & \\
CV template 1a & 1,938 & 0.25 & 0 & 1 \\
CV template 1b & 1,938 & 0.25 & 0 & 1 \\
CV template 2a & 1,938 & 0.25 & 0 & 1 \\
CV template 2b & 1,938 & 0.25 & 0 & 1 \\
Resumes with female names & 1,938 & 0.52 & 0 & 1 \\
Resumes associated with rich neighborhood & 1,938 & 0.50 & 0 & 1 \\
Age of applicant & 1,938 & 26.57 & 24 & 37 \\
Cover letter \# 1 & 1,938 & 0.50 & 0 & 1 \\
\hline \hline
\end{tabular}


Table 32: Dependent variable: if a resume is the first to receive a callback for an interview

(1)

(2)

\begin{tabular}{lcc}
\hline Ethnic minority & 0.017 & 0.018 \\
& {$[0.016]$} & {$[0.016]$} \\
Constant & 0.133 & 0.166 \\
& {$[0.011]^{* * *}$} & {$[0.039]^{* * *}$} \\
Additional controls & & $\mathrm{X}$ \\
Resume template fixed effects & & $\mathrm{X}$ \\
Gender of applicant & & $\mathrm{X}$ \\
Zip code & & $\mathrm{X}$ \\
Week fixed effect & & $\mathrm{X}$ \\
$\quad$ Application letter fixed effects & 1938 & 1938 \\
$\mathrm{~N}$ & 0.001 & 0.020 \\
$\mathrm{R}^{2}$ & & \\
\hline \hline
\end{tabular}

Note: The results are robust to alternative specifications of fixed effects panel estimations. Standard errors (clustered at company level) are in parentheses. ${ }^{*} \mathrm{p}<0.10 ; * * \mathrm{p}<0.05 ; * * \mathrm{p}<0.01$. 
Table 33: Dependent variable: if a resume is the first to receive a callback for an interview

\begin{tabular}{lcc}
\hline \hline & $(1)$ & $(2)$ \\
\hline Karen & 0.059 & 0.060 \\
& {$[0.026]^{* *}$} & {$[0.026]^{* *}$} \\
Chin & -0.001 & 0.003 \\
Kachin & {$[0.025]$} & {$[0.025]$} \\
& 0.010 & 0.011 \\
Shan & {$[0.026]$} & $0.026]$ \\
& 0.001 & 0.000 \\
Constant & {$[0.024]$} & {$[0.024]$} \\
& 0.133 & 0.168 \\
Additional controls & $0.011]^{* * *}$ & {$[0.039]^{* * *}$} \\
Resume template fixed effects & & Yes \\
Gender of applicant & & Yes \\
Zip code & & Yes \\
Week fixed effect & & Yes \\
Application letter fixed effects & & Yes \\
\hline $\mathrm{N}$ & & 1938 \\
$\mathrm{R}^{2}$ & 1938 & 0.022 \\
\hline \hline
\end{tabular}

Note: The results are robust to alternative specifications of fixed effects panel estimations. Standard errors (clustered at company level) are in parentheses. ${ }^{*} \mathrm{p}<0.10 ; * * \mathrm{p}<0.05 ; * * * \mathrm{p}<0.01$. 
Table 34: Callbacks by employers when deciding to call back only one applicant from pairs of Karen Vs Burman applicants, Chin Vs Burman applicants, Kachin Vs Shan applicants, and Shan Vs Burman applicants

\begin{tabular}{|c|c|c|c|c|c|c|c|c|}
\hline & (1) & (2) & (3) & (4) & (5) & (6) & (7) & (8) \\
\hline Karen & $\begin{array}{c}0.353 \\
(0.115)^{* * *}\end{array}$ & $\begin{array}{c}0.345 \\
(0.133)^{* *}\end{array}$ & & & & & & \\
\hline Chin & & & $\begin{array}{c}0.000 \\
(0.134)\end{array}$ & $\begin{array}{c}0.073 \\
(0.163)\end{array}$ & & & & \\
\hline Kachin & & & & & $\begin{array}{l}-0.148 \\
(0.137)\end{array}$ & $\begin{array}{c}-0.269 \\
(0.158)^{*}\end{array}$ & & \\
\hline Shan & & & & & & & $\begin{array}{c}0.077 \\
(0.114)\end{array}$ & $\begin{array}{c}0.103 \\
(0.129)\end{array}$ \\
\hline Constant & $\begin{array}{c}0.324 \\
(0.081)^{* * *}\end{array}$ & $\begin{array}{c}0.381 \\
(0.422)\end{array}$ & $\begin{array}{c}0.483 \\
(0.094)^{* * *}\end{array}$ & $\begin{array}{c}0.572 \\
(0.341)\end{array}$ & $\begin{array}{c}0.556 \\
(0.097)^{* * *}\end{array}$ & $\begin{array}{c}0.613 \\
(0.435)\end{array}$ & $\begin{array}{c}0.462 \\
(0.081)^{* * *}\end{array}$ & $\begin{array}{c}0.634 \\
(0.273)^{* *}\end{array}$ \\
\hline \multicolumn{9}{|l|}{ Additional controls } \\
\hline Resume template fixed effects & & Yes & & Yes & & Yes & & Yes \\
\hline Gender of applicant & & Yes & & Yes & & Yes & & Yes \\
\hline Zip code & & Yes & & Yes & & Yes & & Yes \\
\hline Week fixed effect & & Yes & & Yes & & Yes & & Yes \\
\hline Application letter fixed effects & & Yes & & Yes & & Yes & & Yes \\
\hline $\mathrm{N}$ & 68 & 68 & 58 & 58 & 54 & 54 & 78 & 78 \\
\hline R-sq & 0.125 & 0.201 & 0.000 & 0.175 & 0.022 & 0.341 & 0.006 & 0.124 \\
\hline
\end{tabular}




\section{REFERENCES}

Aigner, Dennis J and Glen G Cain. 1977. "Statistical Theories of Discrimination in Labor Markets." Industrial and Labor relations review, 175-87.

Altonji, Joseph G and Rebecca M Blank. 1999. "Race and Gender in the Labor Market." Handbook of labor economics, 3, 3143-259.

Anwar, Shamena; Patrick Bayer and Randi Hjalmarsson. 2012. "The Impact of Jury Race in Criminal Trials." The Quarterly Journal of Economics.

Ayres, Ian and Peter Siegelman. 1995. "Race and Gender Discrimination in Bargaining for a New Car." The American Economic Review, 304-21.

Bertrand, Marianne; Dolly Chugh and Sendhil Mullainathan. 2005. "Implicit Discrimination." American Economic Review, 94-98.

Bertrand, Marianne and Sendhil Mullainathan. 2004. "Are Emily and Greg More Employable Than Lakisha and Jamal:A Field Experiment on Labor Market Discrimination." American Economic Review, 94(991), 1013.

Butler, Daniel M and David E Broockman. 2011. "Do Politicians Racially Discriminate against Constituents? A Field Experiment on State Legislators." American Journal of Political Science, 55(3), 463-77.

Center for Peace and Conflict Studies. 2010. "Listening to Voices from Inside: Ethnic People Speak."

Correll, Joshua; Bernadette Park; Charles M Judd; Bernd Wittenbrink; Melody S Sadler and Tracie Keesee. 2007. "Across the Thin Blue Line: Police Officers and Racial Bias in the Decision to Shoot." Journal of personality and social psychology, 92(6), 1006.

Darolia, Rajeev; Cory Koedel; Paco Martorell; Katie Wilson and Francisco Perez-Arce. 2014. "Do Employers Prefer Workers Who Attend for-Profit Colleges? Evidence from a Field Experiment."

Doleac, Jennifer L and Luke CD Stein. 2013. "The Visible Hand: Race and Online Market Outcomes." The Economic Journal, 123(572), F469-F92.

Goldin, Claudia and Cecilia Rouse. 2000. "Orchestrating Impartiality: The Impact of "Blind" Auditions on Female Musicians." American Economic Review, 90(4), 715-41.

Government of Burma. 1986. "Burma 1983 Population Census. Rangoon: Central Administration Department."

Kroft, Kory; Fabian Lange and Matthew J. Notowidigdo. 2013. "Duration Dependence and Labor Market Conditions: Evidence from a Field Experiment." The Quarterly Journal of Economics.

Lahey, Joanna N. 2008. "Age, Women, and Hiring an Experimental Study." Journal of Human Resources, 43(1), 30-56.

Leslie, Sarah-Jane; Andrei Cimpian; Meredith Meyer and Edward Freeland. 2015. "Expectations of Brilliance Underlie Gender Distributions across Academic Disciplines." Science, 347(6219), 262-65.

Milkman, Katherine L; Modupe Akinola and Dolly Chugh. 2014. "What Happens Before? A Field Experiment Exploring How Pay and Representation Differentially Shape Bias on the Pathway into Organizations." A Field Experiment Exploring How Pay and Representation Differentially Shape Bias on the Pathway into Organizations (July 11, 2014).

Neumark, David; Ian Burn and Patrick Button. 2015. "Is It Harder for Older Workers to Find Jobs? New and Improved Evidence from a Field Experiment," National Bureau of Economic Research,

Oreopoulos, Philip. 2011. "Why Do Skilled Immigrants Struggle in the Labor Market? A Field Experiment with Thirteen Thousand Resumes." American Economic Journal: Economic Policy, 3(4), 148-71.

Pager, Devah; Bruce Western and Bart Bonikowski. 2009. "Discrimination in a Low-Wage Labor Market: A Field Experiment." American Sociological Review, 74(5), 777-99.

Phelps, Edmund S. 1972. "The Statistical Theory of Racism and Sexism." The American Economic Review, 659-61.

Schulman, Kevin A; Jesse A Berlin; William Harless; Jon F Kerner; Shyrl Sistrunk; Bernard J Gersh; Ross Dube; Christopher K Taleghani; Jennifer E Burke and Sankey Williams. 1999. 
"The Effect of Race and Sex on Physicians' Recommendations for Cardiac Catheterization." New England Journal of Medicine, 340(8), 618-26.

South, Ashley. 2008. Ethnic Politics in Burma: States of Conflict. Routledge.

Thawnghmung, Ardeth Maung. 2011. "Beyond Armed Resistance: Ethnonational Politics in Burma (Myanmar)."

. 2012. The" Other" Karen in Myanmar: Ethnic Minorities and the Struggle without Arms. Lexington Books.

The Republic of the Union of Myanmar. 2014. "The 2014 Myanmar Population and Housing Census: The Union Report."

Turner, Margery Austin. 2013. "Housing Discrimination against Racial and Ethnic Minorities 2012: Executive Summary." 
Appendix K: List of names used in the resumes by ethnic group by gender

\begin{tabular}{lll}
\hline Ethnic group & Male & Female \\
\hline Burmese & Mg Aung Thura & Ma Aye Myat Mon \\
& Mg Thurein Min & Ma Thazin Htun \\
& Mg Kyaw Htet Aung & Ma Ei Mon Kyaw \\
& Mg Arkar Min Htet & Ma Ei Pwint Aung \\
\hline Chin & Salai Chan Pi & Sung Hlei Par \\
& Salai Thla Nawl & Mai Sung Khun \\
& Salai Mon Boei & Mai Hnu Pa Luun \\
& Salai Kee Law Har & Mai Naung Par \\
\hline Karen (Kayin) & Saw Eh Htoo Wah & Naw Eh Khu Phaw \\
& Saw Nay Blute & Naw Khu Khu Wah \\
& Saw Eh Hser Ghay & Naw Hser Wah Paw \\
& Saw Eh Doh Soe & Naw Wah Shee \\
\hline Kachin & Maran Brang Seng & L. Ja Tawng \\
& Maran Hkun San & L Seng Du \\
& Maran Ah Zai & L Ja Seng \\
& Maran Sen Aung & L Ja Pu Pon \\
\hline Shan & Sai Sam Kham & Nang Kong Kham \\
& Sai Kham Sein & Nang Hom Kyauk \\
& Sai Lone Wan & Nang Lyan Zar \\
& Sai Han Linn & Nang Lao Kham \\
\hline \hline
\end{tabular}


Appendix L: Distribution of Sample by Week

\begin{tabular}{cccccc}
\hline \hline Week & $\begin{array}{c}\text { Total job } \\
\text { openings }\end{array}$ & $\begin{array}{c}\text { Sample job } \\
\text { openings }\end{array}$ & $\begin{array}{c}\text { Resumes } \\
\text { submitted }\end{array}$ & $\%$ & Date (2015) \\
\hline 1 & 81 & 55 & 110 & 5.68 & March 23 - March 27 \\
2 & 78 & 58 & 116 & 5.99 & March 30 - April 3 \\
3 & 34 & 23 & 46 & 2.37 & April 6 - April 10 \\
4 & 136 & 71 & 142 & 7.33 & April 20 - April 24 \\
5 & 111 & 60 & 120 & 6.19 & April 27 - May 1 \\
6 & 87 & 54 & 108 & 5.57 & May 4 - May 8 \\
7 & 88 & 55 & 110 & 5.68 & May 11 - May 15 \\
8 & 93 & 52 & 104 & 5.37 & May 18 - May 22 \\
9 & 90 & 54 & 108 & 5.57 & May 25 - May 29 \\
10 & 114 & 64 & 128 & 6.60 & June 1 - June 5 \\
11 & 120 & 61 & 122 & 6.30 & June 8 - June 12 \\
12 & 125 & 57 & 114 & 5.88 & June 15 - June 19 \\
13 & 78 & 48 & 96 & 4.95 & June 22 - June 26 \\
14 & 78 & 39 & 78 & 4.02 & July 6 - July 10 \\
15 & 227 & 100 & 200 & 10.32 & July 13 - July 17 \\
16 & 147 & 58 & 116 & 5.99 & July 20 - July 24 \\
17 & 42 & 24 & 48 & 2.48 & July 27 - July 31 \\
18 & 30 & 17 & 34 & 1.75 & August 3 - August 7 \\
19 & 31 & 19 & 38 & 1.96 & August 10 - August 14 \\
\hline Total & 1,790 & 969 & 1,938 & 100 & \\
\hline \hline
\end{tabular}


Appendix M: List of Variables and Their Detailed Descriptions

\begin{tabular}{|c|c|}
\hline Variable & Description \\
\hline $\mathrm{Y}$ & $\begin{array}{l}\text { Dependent variables: (1) if a resume sent is the first to receive a callback, (2) } \\
\text { if a resume submitted receives a callback conditional on an employer calling } \\
\text { back only one applicant. }\end{array}$ \\
\hline Minority & $\begin{array}{l}\text { A dummy taking a value of } 1 \text { if a resume is associated with a minority, } 0 \\
\text { otherwise (Burmese name is the reference group). }\end{array}$ \\
\hline Shan & $\begin{array}{l}\text { A dummy taking a value of } 1 \text { if a resume is associated with an ethnic Shan } \\
\text { name, } 0 \text { otherwise (Burmese name is the reference group). }\end{array}$ \\
\hline Karen & $\begin{array}{l}\text { A dummy taking a value of } 1 \text { if a resume is associated with an ethnic Karen } \\
\text { name, } 0 \text { otherwise (Burmese name is the reference group). }\end{array}$ \\
\hline Kachin & $\begin{array}{l}\text { A dummy taking a value of } 1 \text { if a resume is associated with an ethnic Kachin } \\
\text { name, } 0 \text { otherwise (Burmese name is the reference group). }\end{array}$ \\
\hline Chin & $\begin{array}{l}\text { A dummy taking a value of } 1 \text { if a resume is associated with an ethnic Chin } \\
\text { name, } 0 \text { otherwise (Burmese name is the reference group). }\end{array}$ \\
\hline Template 1a & $\begin{array}{l}\text { A dummy taking a value of } 1 \text { if a resume is assigned template } 1 \mathrm{a}, 0 \text { otherwise } \\
\text { (template } 1 \mathrm{~b} \text { is the reference group). }\end{array}$ \\
\hline Template 2a & $\begin{array}{l}\text { A dummy taking a value of } 1 \text { if a resume is assigned template } 2 \mathrm{a}, 0 \\
\text { otherwise. }\end{array}$ \\
\hline Template $2 b$ & $\begin{array}{l}\text { A dummy taking a value of } 1 \text { if a resume is assigned template } 2 b, 0 \\
\text { otherwise. }\end{array}$ \\
\hline Female & $\begin{array}{l}\text { A dummy taking a value of } 1 \text { if a resume is associated with a female name, } 0 \\
\text { otherwise (male is the reference group). }\end{array}$ \\
\hline Rich & $\begin{array}{l}\text { A dummy taking a value of } 1 \text { if a resume is associated with a zip code in an } \\
\text { affluent neighborhood, } 0 \text { otherwise (poor neighborhood is the reference } \\
\text { group). }\end{array}$ \\
\hline Week 1-19 & Dummies representing weeks when resumes were submitted. \\
\hline Emails 1 & $\begin{array}{l}\text { Dummies representing application letters \# } 1 \text { (email \# } 2 \text { is the reference } \\
\text { group). }\end{array}$ \\
\hline
\end{tabular}


Appendix N: Institutional Review Board (IRB) Approval

Protocols, which form the basis for executing this research, were reviewed and approved by the Human Subjects Protection Committee at the RAND Corporation in March, 2015 (Assurance number is FWA00003425; IRB number is IRB0000005). The IRB does not allow me to release any identifying information about the employers including names and addresses.

However, I was allowed to preserve and use information on the job characteristics posted on the job advertisements. 